\author{
UNIVERSIDADE DE SÃO PAULO \\ FACULDADE DE FILOSOFIA, LETRAS E CIÊNCIAS HUMANAS \\ DEPARTAMENTO DE GEOGRAFIA \\ PÓS-GRADUAÇÃO EM GEOGRAFIA HUMANA
}

\title{
Turismo e Produção do Espaço no Litoral de Pernambuco
}

ADRIANA GARCIA DE CARVALHO

São Paulo

2009 


\section{UNIVERSIDADE DE SÃO PAULO \\ FACULDADE DE FILOSOFIA, LETRAS E CIÊNCIAS HUMANAS DEPARTAMENTO DE GEOGRAFIA \\ PÓS-GRADUAÇÃO EM GEOGRAFIA HUMANA}

\section{Turismo e Produção do Espaço no Litoral de Pernambuco}

Adriana Garcia de Carvalho

Dissertação de mestrado apresentada ao Programa de Pós-Graduação em Geografia Humana, do Departamento de Geografia da Faculdade de Filosofia, Letras e Ciências Humanas da Universidade de São Paulo, para a obtenção do título de Mestre em Geografia Humana.

Orientadora: Prof ${ }^{a}$. Drª. Neli Aparecida de Mello 
Dedico este trabalho a João, meu querido e amado marido, que uma vez sem ele eu não teria chegado aqui. 
"Não basta ensinar ao homem uma especialidade, porque se tornará assim uma máquina utilizável e não uma personalidade. É necessário que adquira um sentimento, senso prático daquilo que vale a pena ser empreendido, daquilo que é belo, do que é moralmente correto".

\section{ALBERT EINSTEIN}




\section{AGRADECIMENTOS}

Com esse trabalho de dissertação já concluído, é que em primeiro lugar agradeço a Deus o êxito de ter chegado ao fim é Ele quem me guia e quem me conduz nessa vida.

À minha orientadora Prof ${ }^{a}$. Dr ${ }^{a}$. Neli Aparecida, agradeço pela dedicação e que me norteou pelos caminhos corretos, me repreendendo sempre que necessário e incentivando para que eu concluísse mais essa etapa.

A meu querido marido João Bosco. Essa dissertação é fruto da sua ajuda e insistência, sempre me mostrando o quanto eu sou capaz. Obrigada por todas as horas de leitura e correções e dedicação.

Aos meus familiares, a quem tanto amo e sou feliz por causa da existência de cada um deles.

A todos os professores que tive na USP, que me ensinaram não só sobre Turismo, mas como eu posso entendê-lo de uma forma muito mais ampla, especialmente à professora e Drâ. Rita de Cássia Cruz por todas as vezes que ela me ajudou sem objeções e com toda sabedoria colaborou muito para este trabalho.

Aos meus amigos da USP, em especial ao Fabiano Leite, que me ajudou em todas as vezes que gritava por socorro e aos amigos da Faculdade Maurício de Nassau, pela paciência, colaboração com textos e dicas, pelas demonstrações de carinho e de confiança que eu poderia concluir essa fase da minha vida acadêmica.

Ao CNPQ por me fornecer subsídios para que eu pudesse concluir o presente trabalho. 


\section{RESUMO}

Este trabalho busca investigar se o turismo impôs de alguma maneira uma nova forma de organização socioespacial do litoral pernambucano, uma vez que a atividade turística ao chegar numa localidade, tem o poder de transformação não só enquanto uma atividade econômica, mas como também social. Desta forma buscou-se compreender como se deu o processo de ocupação do litoral de Pernambuco, aprofundando o trabalho na temática das políticas públicas e como as mesmas incentivaram, ou não, essa ocupação. Por meio das visitas in loco percebeu-se a grande influência da atividade turística, seja pela existência dos equipamentos turísticos ou ainda de maneira mais significativa retratada em forma de segundas residências.

Palavras-Chave: Turismo, espaço, Pernambuco, litoral e segundas residências 


\begin{abstract}
This paper investigate whether tourism has, in any way, imposed a new form of social-space organization on Pernambuco's coast, as the tourism activity has the power to change a new location not only as an economic activity, but also as social. Thus, we tried to understand how was the occupation process of the coast of Pernambuco, deepening the work on the subject of public policies and how they encouraged, or not, this occupation. Through site visits, it was possible to perceived the high influence of tourism activity by the existence of tourist facilities or even a more significant portrayed, in the form of second homes.
\end{abstract}

Keywords: Tourism, space, Pernambuco, coastal and second homes 


\section{SUMÁRIO}

1 INTRODUÇÃO

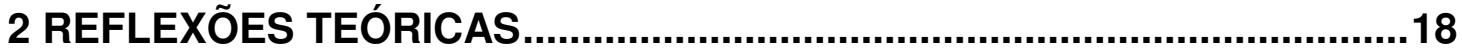

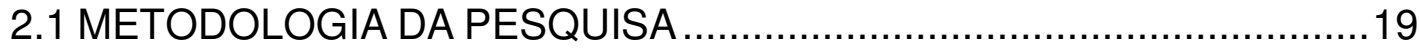

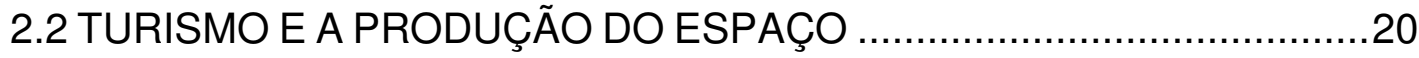

2.3 O PAPEL DO ESTADO NA ATIVIDADE TURÍSTICA ...........................27

2.4 AÇÕES DO ESTADO NO TURISMO DE PERNAMBUCO.....................33

3 O PROCESSO DE OCUPAÇÃO DO LITORAL PERNAMBUCANO ...........47

3.1 A ZONA COSTEIRA DE PERNAMBUCO E O PROCESSO DE

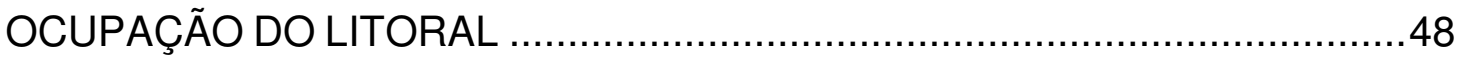

3.2 A OCUPAÇÃO DO LITORAL EM PERNAMBUCO …...........................54

3.3 A INSTALAÇÃO DE SEGUNDAS RESIDÊNCIAS ...............................57

4 TURISMO E PRODUÇÃO DO ESPAÇO NO LITORAL DE PERNAMBUCO

4.1 CONHECENDO O LITORAL DE PERNAMBUCO ….............................63

4.2 A SETORIZAÇÃO DA ZONA COSTEIRA PERNAMBUCANA ................66

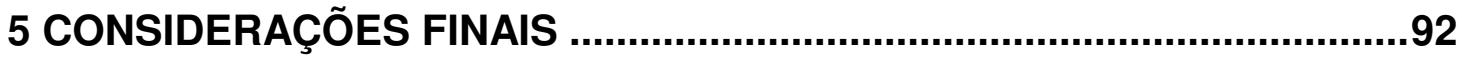

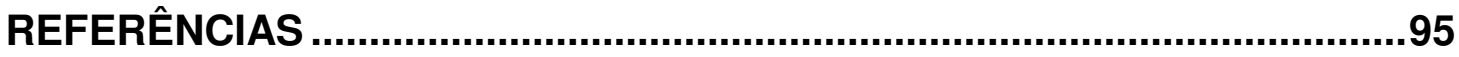




\section{LISTA DE TABELAS}

TABELA 1 - NECESSIDADES E VISÕES DOS DIFERENTES ATORES SOCIAIS ….....................45

TABELA 2 - FluXo GLOBAL DE TURISTAS DE PERNAMBUCO.........................................64

TABELA 3 - DADOS FíSICOS, SOCIAIS E ECONÔMICOS DO LITORAL NORTE ........................67

TABELA 4 - DAdOS FíSICOS, SOCIAIS E ECONÔMICOS do LitoRAL METROPOLITANO ...........72

TABELA 5 - DADOS FÍSICOS, SOCIAIS E ECONÔMICOS DO LITORAL SUL..............................75

TABELA 6 - INFORMAÇÕES COLETADAS NO TRABALHO DE CAMPO ……….....................86 


\section{LISTA DE GRÁFICOS}

GRÁFICO 1 - MODALIDADES DE ACOMODAÇÃO ................................................. 83

GRÁFICO 2 - LOJAS PARA TURISTAS .......................................................... 83

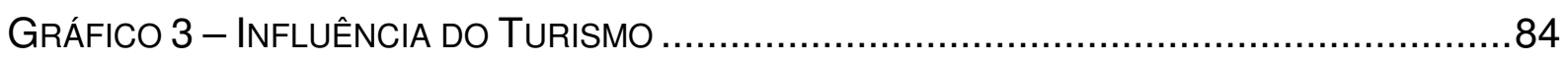

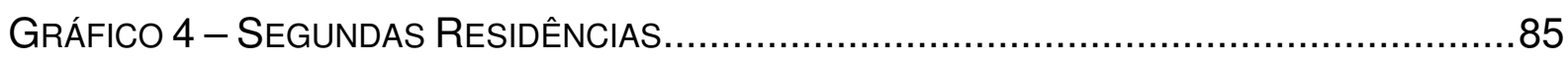

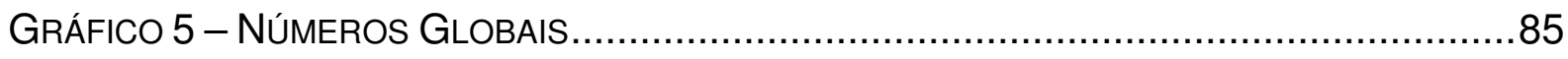




\section{LISTA DE MAPAS}

Mapa 1 - Municípios do Estado de Pernambuco que fazem parte do Planejamento

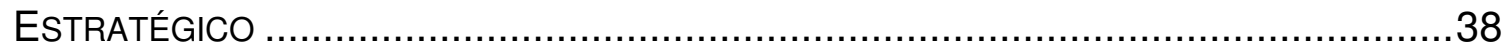

Mapa 2 - SetorizaÇÃo dA Zona Costeira de Pernambuco …….............................56 


\section{LISTA DE FOTOS}

Foto 1- Vista AÉREa - NanNai Resort, em Muro Alto...............................................40

FOTO 2 - OBRA FINANCIADA PELO PRODETUR-NE ............................................. 44

Foto 3 - Manguezal na Praia dos Carneiros, Litoral SUl do ESTADo ..................49

Foto 4 - Segunda residência na Praia de Toquinho, Litoral sul de Pernambuco .58

Foto 5 - BARREIRAS DE PROTEÇÃO, PRAIA DE MURO ALTO, LITORAL SUL DO ESTADO. .....60

FOTO 6 - BARCOS USADOS NA PESCA ARTESANAL NO LITORAL NORTE. ..........................69

FOTO 7 - SEGUNDAS RESIDÊNCIAS NA PRAIA DE CARNE DE VACA, LITORAL NORTE. ...........70

FOTO 8 - ANTIGO HOTEL NA PRAIA DE ITAMARACÁ, LITORAL NORTE...............................71

Foto 9 - PLACA DE ADVERTÊNCIA REFERENTE AOS ATAQUES DE TUBARÃO NA PRAIA DE BOA

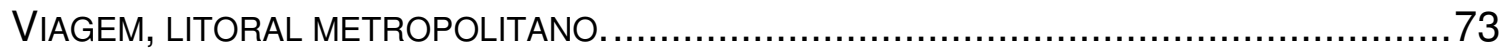

FOTO 10 - PRÉDIOS NA PRAIA DE BOA VIAGEM, LITORAL METROPOLITANO. .....................74

FOTO 11 - BANHISTAS NAS PISCINAS NATURAIS DE PORTO DE GALINHAS, LITORAL SUL......81

FOTO 12 - BANHEIROS Públicos LOCALIZADOS NA PRAIA DE GAMELA, LITORAL SUL. ........90

FOTO 13 - PLACA DE SINALIZAÇÃO, PRAIA DE ITAMARACÁ, LITORAL NORTE......................90 


\section{LISTA DE ABREVIATURAS E SIGLAS}

\begin{tabular}{|c|c|}
\hline PRODETUR-NE & Programa de Desenvolvimento do Turismo no Nordeste \\
\hline CONDEPE-FIDEM & $\begin{array}{l}\text { Agência Estadual de Planejamento e Pesquisas do } \\
\text { Estado de Pernambuco }\end{array}$ \\
\hline $\mathrm{CPRH}$ & Agência Estadual de Meio Ambiente e Recursos Hídricos \\
\hline BID & Banco Interamericano de Desenvolvimento \\
\hline PNGC & Plano Nacional de Gerenciamento Costeiro \\
\hline SEPLANDES & Secretaria de Planejamento de Desenvolvimento Social \\
\hline GERCO/PE & $\begin{array}{l}\text { Programa Nacional de Gerenciamento Costeiro - } \\
\text { Pernambuco }\end{array}$ \\
\hline IBGE & Instituto Brasileiro de Geografia e Estatística \\
\hline UNESCO & $\begin{array}{l}\text { Organização das Nações Unidas para educação, ciência } \\
\text { e cultura }\end{array}$ \\
\hline SETUR/PE & Secretaria de Turismo de Pernambuco \\
\hline FPA & Frente Polar Atlântica \\
\hline PNUD & Programa das Nações Unidas para o desenvolvimento \\
\hline IPEA & Instituto de Pesquisas Econômicas Aplicadas \\
\hline FJP & Fundação João Pinheiro \\
\hline DATASUS & Banco de dados do Sistema Único de Saúde \\
\hline PROÁLCOOL & Programa Nacional do Álcool \\
\hline EMPETUR & Empresa de Turismo de Pernambuco \\
\hline
\end{tabular}




\section{INTRODUÇÃO}

A presente seção mostra as principais razões para a realização deste trabalho e seu objetivo, explicitando a relação existente entre turismo e o campo da Geografia, para, posteriormente apresentar a estrutura completa desta dissertação. 
Nos últimos anos, a temática do turismo vem atraindo pesquisadores das mais variadas formações e especialidades, que encontram no mesmo um campo novo, cada vez mais rico e complexo de estudos. Do ponto de vista da geografia, é possível relacionarmos o turismo com conceitos pertinentes ao saber geográfico como, por exemplo, "lugar" e "território".

Na Ciência Geográfica, a atividade turística tem ainda um relevante manancial teórico-metodológico para sua prática social e ambiental, e suas abordagens a respeito do território, acabam servindo de sustentação para uma visão espacial no tocante a mesma.

Desta forma, a atividade turística influencia de sobremaneira as relações que se dão sobre o território e modifica todo um sistema de objetos preexistentes, conforme vem ocorrendo no Estado de Pernambuco e será evidenciado ao longo deste trabalho.

O turismo do ponto de vista geográfico pode produzir e reproduzir espaços, construir, reconstruir e até por vezes destruir identidades, além de mudar as funções de alguns espaços por projetar-se diferentemente no território das mais variadas formas. Esses fatores reforçam a importância de estudá-lo, com 0 olhar aprofundado, no âmbito da geografia.

O presente trabalho tem por objeto de estudo a transformação do litoral de Pernambuco com a chegada do Turismo, levando em consideração o seu processo de ocupação, as políticas públicas de incentivo às atividades vigentes no Estado e os atores envolvidos nesse processo.

Desse modo, como pergunta norteadora do presente trabalho, questiona-se se o turismo impôs de alguma maneira uma nova forma de organização socioespacial do litoral pernambucano, uma vez que, ao abordar a temática do turismo, a relação com o espaço torna-se inevitável. 
O Estado, enquanto ator que tende a monopolizar as ações básicas do processo de formação territorial, também mereceu destaque no presente trabalho. Os territórios estão vinculados ao domínio estatal do espaço, onde as sociedades, para se reproduzirem, criam formas que obedecem a um dado ordenamento sociopolítico dos grupos que as constroem, respondendo a uma sociabilidade vigente e a uma dada regulação do uso do espaço e dos recursos nele contidos. (MORAES, 2002)

O turismo no Nordeste consegue ter maior destaque a partir do final da década de 1970 e após a elaboração de duas políticas regionais de turismo intituladas de "política de megaprojetos turísticos" e "Programa de Ação para o Desenvolvimento do Turismo no Nordeste - PRODETUR-NE". As mesmas foram consideradas marcos para o favorecimento da atividade na região (CRUZ, 2002). O Estado de Pernambuco foi contemplado com ações de ambas as políticas.

No que diz respeito às políticas públicas de turismo, sabe-se que as mesmas devem integrar-se a outras setoriais já que esta atividade ocorre dentro de um contexto mais amplo da sociedade envolvendo também os aspectos sociais, ambientais e econômicos, a partir das políticas para o turismo, em função das repercussões sociais, econômicas e políticas, configuram-se significativas mudanças na organização do espaço, o que torna essencial uma abordagem que justamente atente para esses aspectos, já que este campo de pesquisa é dominado pela visão econômica (KNAFOU, 2001).

Além das políticas públicas, o fenômeno das segundas residências também teve papel importante nessa organização do espaço no litoral brasileiro e em Pernambuco não foi diferente, onde o referido estado tem seu litoral dividido em três setores: o norte, o sul e o metropolitano. O Litoral norte teve seu apogeu na década de oitenta e ainda estendeu-se até final da década de noventa, quando Porto de Galinhas, no litoral sul, começou a destacar-se na mídia e os freqüentadores habituais e turistas passaram a deslocar-se para lá. 
A realização deste estudo exigiu um aprofundamento nos conceitos e idéias de diversos estudiosos ${ }^{1}$, principalmente os que abordam o turismo no contexto da configuração socioespacial, a produção do espaço, sua relação com o turismo e as políticas públicas, além disso, autores que escreveram sobre a dinâmica da atividade turística, no Nordeste e Pernambuco em especial também foram referenciados.

Para compreender o objeto descrito, não só se procedeu à investigação teórica, como também foram colhidos dados ao longo de todo o litoral pernambucano, onde se constatou a presença da atividade turística ordenando um sistema de objetos animados por um sistema de ações (SANTOS, 1996). Os objetos requeridos pelo turismo, como é o caso de meios de transportes, de hospedagem, de serviços turísticos, fazem parte dessa "engrenagem" que o turismo traz consigo.

O conceito de espaço trabalhado aqui é baseado na definição de Santos (1996, p.50), onde o mesmo "é formado por um conjunto indissociável, solidário e também contraditório, de sistemas de objetos e sistema de ações, não considerados isoladamente, mas como o quadro único no qual a história se dá". O autor acrescenta ainda que atualmente o espaço seja um sistema de objetos cada vez mais artificiais, povoados por sistema de ações igualmente imbuídos de artificialidade, e mais tendentes a fins estranhos ao lugar e seus habitantes. Sistemas de objetos e sistema de ações interagem. De um lado, os sistemas de objetos condicionam a forma como se dão as ações e, de outro lado, o sistema de ações leva à criação de objetos novos ou se realiza sobre objetos preexistentes. Para o mesmo, é assim que o espaço encontra sua dinâmica e se transforma.

${ }^{1}$ Araújo (2007), Carlos (1996), (1999) e (2001), Cruz (2002) e (2005), Lima (2006), Madruga (1992), Moraes (1999), (1988) e (2000), Santos (1994), (1996) e (2000), Yázigi (2002), Barreto (2001), Dias ( 2003) e Boyer (2003). 
Na segunda seção do presente trabalho, o turismo e a produção do espaço foram conceituados e analisados em conjunto, relacionando-os às políticas públicas de incentivo à atividade de uma forma mais generalizada. Também foi dado um enfoque no Estado de Pernambuco e o papel do Poder Público, no qual as políticas de megaprojetos, o PRODETUR-NE, e os atores sociais envolvidos foram também abordados.

Na terceira seção, a zona costeira de Pernambuco e o processo de ocupação do litoral merecem destaque, resgatando sua história para poder entender a sua configuração no presente. Outro elemento norteador do uso do espaço litorâneo são as segundas residências, que possuem um papel importante nessa configuração espacial e por isso são estudadas também neste item.

$\mathrm{Na}$ quarta seção, aborda-se o turismo e a produção no espaço do litoral Pernambucano, além de detalhar seus três setores: norte, metropolitano e sul; apresenta também a análise dos dados e resultados compilados do trabalho de campo, levantando informações importantes em cada praia do Estado, para saber a existência ou não de modalidades de acomodações, meios de circulação, lojas para turistas, segundas residências e a influência do turismo em cada localidade.

A quinta e última seção apresenta as considerações finais. 


\section{REFLEXÕES TEÓRICAS}

A presente seção aborda as temáticas, teorias e métodos que servirão de base para a pesquisa e suas interseções com o turismo e mais especificamente no tocante ao litoral pernambucano. Serviu como base para a elaboração disto autores como Rita Cruz, Milton Santos, Ana Fani Alessandri Carlos e Antônio Moraes, levantando teorias e dissertando sobre turismo e produção do espaço. 


\subsection{METODOLOGIA DA PESQUISA}

Com a finalidade de dar suporte teórico-metodológico ao alcance do objetivo proposto neste trabalho, foram realizadas pesquisas bibliográficas, usando as técnicas de documentação direta e indireta, no primeiro caso, por meio de legislações pertinentes á área e no segundo em livros, publicações e periódicos, além de sites correlacionados; além disso, foram realizadas visitas de reconhecimento da situação em todo o litoral de Pernambuco e buscas através de documentários em órgãos públicos, elaboradores e executores da política pública, como, por exemplo, a Agência Estadual de Planejamento e Pesquisas de Pernambuco (CONDEPE-FIDEM) e a Agência Estadual de Meio Ambiente e Recursos Hídricos (CPRH), a fim de coletar dados mais precisos e atuais.

Há uma infinidade de abordagens metodológicas de pesquisas que permite que 0 investigador possa analisar o seu objeto por ângulos diversos dando uma maior credibilidade ao seu trabalho. Este estudo trata de uma pesquisa descritiva onde Gil (1991) esclarece que tem como objetivo principal o detalhamento das características referentes a um determinado grupo populacional e ou de um fenômeno localizado.

Respondendo a este tipo de pesquisa Bervian e Cervo (1996, p.49) afirmam que:

A pesquisa descritiva observa, registra, analisa e correlaciona fatos
ou fenômenos (variáveis) sem manipulá-los. Procura descobrir, com
a precisão possível, a freqüência com que um fenômeno ocorre, sua
relação e conexão com outros, sua natureza e características. Busca
conhecer as diversas situações e relações que ocorrem na vida
social, política e econômica e demais aspectos do comportamento
humano, tanto do indivíduo tomado isoladamente como de grupos e
comunidades mais complexas.

A observação e o registro foram feitos no litoral pernambucano, onde durante dois meses a pesquisadora visitou todas as suas praias buscando constatar informações 
levantadas anteriormente ao trabalho de campo. A análise foi feita paralelamente e posteriormente a coleta de dados.

A escolha por este tipo de pesquisa deve-se ao fato dela favorecer as expectativas de investigação do fenômeno estudado. Conforme Martins (1991), a partir da observação entre os fatos, constrói-se elementos significativos para desvendar as questões pertinentes ao objeto de estudo.

Miles e Huberman (1994) não apresentam uma definição rígida do termo pesquisa qualitativa, mas destacam algumas características recorrentes da pesquisa naturalística, encontradas nessa abordagem: contato prolongado com o campo ou a situação real, o papel do pesquisador em garantir uma visão holística do fenômeno e capturar os dados por meio das percepções dos atores locais, suspendendo seus preconceitos sobre os tópicos pesquisados.

\subsection{TURISMO E A PRODUÇÃO DO ESPAÇO}

Como suporte teórico, alguns conceitos foram fundamentais para esta pesquisa, onde é levado em consideração o turismo como uma prática social que tem o espaço como principal objeto de consumo, eivada de significado cultural, e cooptada pelo mercado, é cada vez mais um agente da transformação do espaço em mercadoria (CRUZ, 2005).

$\mathrm{Na}$ visão de Moesch (2002, p.9), o turismo é uma combinação complexa de interrelacionamentos entre produção e serviços, em cuja combinação integra-se a uma prática com base cultural, com herança a um meio ambiente diverso.

A visão das duas autoras consiste em definir o turismo no âmbito social e cultural, porém, numa abordagem mais técnica, o conceito Ansarah (2001, p.73) nos diz que: 
Genericamente, pode-se dizer que o turismo é o deslocamento temporário de pessoas, com intenção de retorno ao ponto de origem. Para atender esse deslocamento, faz-se necessária a utilização de toda uma infra-estrutura, em geral diferente daquela cotidiana, que visará suprir os anseios e as necessidades dessas pessoas durante o período de viagem [...] Dessa forma, o turismo é visto como um fenômeno que envolve tanto a interação entre o turista e o núcleo receptor, como todas as atividades proporcionantes ou decorrentes dessa interação.

Percebe-se que nas três visões o espaço está sendo citado, mesmo que indiretamente, já que é nele onde a atividade turística se desenvolve.

Para Carlos (2001), o espaço é o lugar onde se manifesta a vida. Ele é condição, meio e produto da realização da sociedade humana em toda sua multiplicidade. Se de um lado o espaço é um conceito abstrato, de outro tem uma dimensão real e concreta como lugar de realização da vida humana, que ocorre diferentemente no tempo e no lugar e que ganha materialidade por meio do território.

Ainda para a autora, a produção do espaço deve ser entendida sob dupla perspectiva: ao mesmo tempo em que se realiza um movimento que constitui o processo de mundialização da sociedade urbana, acentua-se a fragmentação tanto do espaço quanto do indivíduo. Essa produção realiza-se no plano da vida cotidiana e aparece como forma de ocupação e uso de determinado lugar, em um movimento específico. Desse modo, o espaço dominado, controlado, impõe novos modos de apropriação, pelo estabelecimento de novos usos que excluem/incluem os habitantes.

Por suas ações, a sociedade não apenas aceita o espaço como um receptáculo, mas o produz. Nós não vivemos, atuamos ou trabalhamos "no" espaço, mas sim produzimos o espaço, vivendo, atuando e trabalhando. (SMITH, 1988) 
O turismo enquanto um fenômeno social e que tem por objeto de consumo o espaço, transforma-o em mercadoria pela sua lógica capitalista, uma vez que esta atividade não está alheia ao que acontece no mundo, pelo contrário, o mesmo também é ditado pelas normas atuais vigentes. Ele é apenas um pequeno ponto na totalidade que é grande e modifica-se a cada dia e por isso acredita-se que para estudar tal fenômeno, faz-se necessário olhá-lo não sob sua própria ótica, mas sim sob a ótica de um todo, pertencente a um mundo de controvérsias, interesses, mudanças repentinas, entre tantas outras características vigentes no atual contexto social.

Para Carlos (1996), o setor turístico compõe-se de uma multiplicidade de atividades que inicialmente referem-se à produção concreta de um lugar: delimitação espacial, criação de infra-estrutura de todos os tipos, desde estreitos caminhos, a autoestradas, heliportos, aeroportos, hotéis, ruas, centros comerciais, áreas de restaurantes, podendo comportar cidades inteiras. Inclui-se também a criação de maravilhosas cascatas artificiais, ou mesmo cenários exuberantes que descaracterizam e não guardam nenhuma semelhança com o lugar original.

A análise do mundo moderno coloca-se diante de uma série de desafios, decorrentes das transformações aceleradas provocadas pelo processo de globalização como produto de desenvolvimento do capitalismo, que destrói barreiras e ultrapassa obstáculos, como conseqüência de sua realização. Isso significa que áreas inteiras do planeta, antes desocupadas, são divididas entrando no processo de comercialização. Cada vez mais o espaço é produzido por novas indústrias como aquela do turismo e, deste modo, praias, montanhas e campos entram no circuito da troca, sendo apropriadas como áreas de lazer privativas, apenas para quem possa fazer uso delas (CARLOS 1996).

Aliado a expansão do turismo, surge a necessidade de utilizar técnicas que facilitem e gerenciem o desenvolvimento desta expansão. Segundo Silveira (1999), inovações técnicas e novas ações de empresas de forças diversas, como os vários 
segmentos do Estado, de grupos e corporações, difundem-se num pedaço do planeta, modificando o dinamismo preexistente e criando uma nova organização de variáveis.

Santos (1996) diz que o tema da relação entre a técnica e o espaço é também objeto do interesse de geógrafos como Pierre George. Essa preocupação é exposta em A Técnica: Construções ou Destruições (1974), onde Pierre lembra que "a influência da técnica sobre o espaço se exerce de duas maneiras e em duas escalas diferentes: a ocupação do solo pelas infra-estruturas das técnicas modernas (fábricas, minas, etc.) e, de outro lado, as transformações generalizadas impostas pelo uso da máquina e pela execução dos novos métodos de produção e de existência".

As técnicas pertinentes ao desenvolvimento dos meios de transportes, à ampliação de estradas, técnicas informacionais, entre outros, favoreceram diretamente o turismo, onde o deslocamento é condição sine qua non para sua existência e quanto mais rápida e eficaz esses meios, mais a atividade turística será beneficiada.

As técnicas encontraram no capitalismo uma ferramenta básica para o seu alastramento, momento propício de difusão e propagação das mesmas por meio da sociedade emergente do consumo. O turismo também busca nas técnicas formas de alastrar-se e, muitas vezes, de se "instalar" de forma mais eficaz, para isso utiliza-se de sobremaneira das mesmas.

Milton Santos traz importantes contribuições referentes ao tema aqui discutido quando no seu livro, Técnica, espaço, tempo: globalização e meio técnico-científico informacional, diz que a natureza artificializada marca uma grande mudança na história humana da natureza e que hoje, com a tecnociência, alcançamos o estágio supremo dessa evolução. E que culmina, na fase atual, onde a economia tornou-se mundializada, e todas as sociedades terminaram por adotar, de forma mais ou 
menos total, de maneira mais ou menos explícita, um modelo técnico único que se sobrepõe à multiplicidade de recursos naturais e humanos (SANTOS, 1994).

O autor diz ainda que fomos rodeados, nestes últimos quarenta anos, por mais objetos do que nos quarenta mil anos precedentes. Mas sabemos muito pouco sobre o que nos cerca. A natureza tecnicizada acaba por ser uma natureza abstrata, já que as técnicas, no dizer de G. Simondon (1989) apud Santos (1994), insistem em imitála e a acabam conseguindo.

As técnicas também foram cooptadas pelo turismo. Yázigi (2002), em seu livro Turismo e Paisagem, fala a respeito dos simulacros na atividade turística, dizendo que: o olhar do turista está predeterminado pelos modelos e imagens pré-formadas, que a mídia, a indústria cultural e a publicidade porfiam em cristalizar, assim como pelas fotografias, vídeos e recordações dos parentes, amigos e colegas competidores.

No turismo, muitas vezes, reconhecem-se imagens antes veiculadas, mas não se estabelece uma relação com o lugar, não se descobre seu significado, pois os passos são guiados por rotas, ruas preestabelecidas por roteiros de compras, gastronômicos, históricos, virando um ponto de passagem. Os passos dos turistas são sempre apressados, aí não se fica, só se deixa passar. Fragmentam-se os lugares, exclui-se o feio, afasta-se o turista do pobre, do usual; trajetos feitos por ônibus refrigerados ou vans com guias de fala mansa e agradável, sempre bem disposto, sorriso nos lábios, naquele estilo absolutamente igual em todo lugar, estereotipado, que infantiliza o turista, onde o lugar é apenas o que pode ser visto, fotografado e depois esquecido. (ZUKIN,1996 apud YÁZIGI, 2002)

O turismo, como um fenômeno social e econômico, sofre de manipulações de interesse dos atores hegemônicos. As técnicas "apropriadas" pelo turismo são também responsáveis pelo crescimento da atividade, basta só que sejam conduzidas para o bem-estar comum, visando não só o lucro exacerbado, mas o 
próprio propósito da atividade; contribuir para a expansão econômica das localidades, a compreensão internacional, a paz e a prosperidade dos países, bem como para o respeito universal e a observância dos direitos do homem e das liberdades fundamentais, sem distinção de raça, sexo, língua ou religião².

As questões referentes ao espaço e sua produção são essenciais para entender como o turismo se dá em determinadas regiões, pois antes mesmo dessa atividade instalar-se nos lugares já havia um cotidiano, com suas normas, suas características e sua lógica.

Para os seguidores da corrente humanística, o lugar é principalmente um produto da experiência humana: "(...) lugar significa muito mais que o sentido geográfico de localização. Não se refere a objetos e atributos das localizações, mas à tipos de experiência e envolvimento com o mundo, a necessidade de raízes e segurança" (Relph, 1979). Ou ainda, "lugar é um centro de significados construído pela experiência" (Tuan, 1975). Trata-se na realidade de referenciais afetivos os quais desenvolvemos ao longo de nossas vidas a partir da convivência com o lugar e com o outro. Eles são carregados de sensações emotivas principalmente porque nos sentimos seguros e protegidos (Mello, 1990). Ele tanto nos transmite boas lembranças, quanto a sensação de lar (Tuan, 1975; Buttimer, 1985a). Nas palavras de Buttimer (1985b, p. 228), "lugar é o somatório das dimensões simbólicas, emocionais, culturais, políticas e biológicas" (LEITE, 1998, p.10).

Quando o turismo instala-se no lugar, traz consigo novas demandas. Entra requerendo mudanças e na maior parte das vezes, acaba criando espaços demasiadamente fragmentados e dominados pelos interesses hegemônicos e capitalistas.

\footnotetext{
${ }^{2}$ Código Mundial de Ética do Turismo, 1999.
} 
Em Pernambuco não foi diferente. A atividade turística iniciou-se principalmente no litoral, elegendo e fragmentando espaços inicialmente na forma de segundas residências, e logo em seguida, através dos meios de hospedagem. Em Olinda surgiu há mais de 40 anos o Hotel Quatro Rodas, o primeiro cinco estrelas no Estado. Nos anos oitenta surgiram outros importantes como o Hotel Forte Orange e Amoaras na Praia de Itamaracá, o Hotel Gavoa na praia de Maria Farinha, o Hotel Tavares Correia na praia do Pina, o Grande Hotel no centro do Recife, o Vila Rica, o Hotel Castelinho e a Pousada das Acácias em Boa Viagem, onde desde a década de 40 começou o fenômeno das segundas residências.

A época áurea das construções dos hotéis em Pernambuco aconteceu entre as décadas de setenta e oitenta, com um período de estagnação na década de noventa durante o Governo de Miguel Arraes por falta de investimento do poder público, visto que o citado governador não acreditava na atividade turística como fonte de renda significativa para o Estado. Outro motivo para a estagnação baseia-se no fato de que os usineiros que constituíam grande parte dos investidores em hotelaria, com a chegada do Proálcool, programa de incentivo do Governo ao uso de álcool em veículos e que aqueceu o mercado de produção de cana, "abandonaram" este tipo de investimento para voltar-se ao cultivo da cana-de-açúcar.

Moraes (2000) nos fala que cabe lembrar que os lugares se diferenciam não apenas por características naturais, mas também pelas intervenções humanas ali realizadas e pelas relações com seus entornos e outros lugares. Logo, a relação sociedade/espaço não pode ter sua explicação remetida apenas à lógica societária prevalecente numa época, pois esta tem que reagir a diferentes situações, gerando novas particularidades.

Ainda segundo o autor, toda sociedade, para se reproduzir, cria formas na superfície terrestre mais ou menos duráveis, daí sua condição de processo universal. Formas que obedecem a um dado ordenamento sócio-político do grupo que as constrói, que respondem funcionalmente a uma sociabilidade vigente, a qual inclusive regula 0 
uso do espaço e dos recursos nele contidos, definindo os seus modos próprios de apropriação da natureza. Esta vivência social do espaço cria rugosidades ${ }^{3}$ que duram mais que os estímulos e objetivos que lhes deram origem.

O turismo também cria essas rugosidades, na medida em que modifica o espaço com seus objetos requeridos. O mesmo contém relações que podem ser um reflexo da sociedade, portanto, assim como o capital é seletivo e segregador do ponto de vista espacial, a atividade turística também o é.

\subsection{O PAPEL DO ESTADO NA ATIVIDADE TURÍSTICA}

A fragmentação é decorrente da ação dos diversos agentes modeladores que produzem e consomem espaço urbano: proprietários dos meios de produção sobretudo os grandes industriais, proprietários fundiários, promotores imobiliários, grupos socialmente excluídos e Estado.

O papel do Poder Público no turismo é de extrema relevância e até mesmo uma questão de "sobrevivência" e "perpetuação" da atividade turística. É por meio de suas ações, normas, políticas e incentivos que o turismo se organiza e se estabelece na localidade.

A política pública, enquanto área de conhecimento e disciplina acadêmica nasceu nos Estados Unidos da América - EUA, rompendo ou pulando as etapas seguidas pela tradição européia de estudos e pesquisas nessa área, que se concentravam, então, mais na análise sobre o Estado e suas instituições do que na produção dos governos. Assim, na Europa a área de política pública vai surgir como um

${ }^{3}$ Chamamos de rugosidade ao que fica do passado como forma, espaço construído, paisagem, o que resta do processo de supressão, acumulação, superposição, com que as coisas se substituem e acumulam em todos os lugares. (SANTOS, 1996) 
desdobramento dos trabalhos baseados em teorias explicativas sobre o papel do Estado e de uma das mais importantes instituições do Estado, o Governo, produtor por excelência de políticas públicas. (SOUZA, 2006)

A mesma autora nos fala ainda que não existe uma melhor definição sobre o que seja política pública que as de Mead (1995), definindo-a como um campo dentro do estudo da política que analisa o Governo à luz de grandes questões públicas e a de Lynn (1980), colocando-a como um conjunto de ações do Governo que irão produzir efeitos específicos. Peters (1986) segue o mesmo veio: política pública é a soma das atividades dos Governos, que agem diretamente ou através de delegação, e que influenciam a vida dos cidadãos. Dye (1984) sintetiza a definição de política pública como "o que o Governo escolhe fazer ou não fazer". Pode-se, então, resumir política pública como o campo do conhecimento que busca, ao mesmo tempo, colocar o governo "em ação" e/ou analisar essa ação (variável independente) e, quando necessário, propor mudanças no rumo ou curso dessas ações (variável dependente). (SOUZA, 2006, p.26)

No Turismo, as políticas públicas, conforme dito anteriormente, determinam como a atividade será conduzida na localidade.

O modo como se dá a apropriação de uma determinada parte do espaço geográfico pelo turismo depende fundamentalmente da política pública de turismo que se leva a cabo no lugar. A política pública de turismo cabe o estabelecimento de metas e diretrizes que orientem o desenvolvimento socioespacial da atividade, tanto no que tange à esfera pública como no que se refere à iniciativa privada. $\mathrm{Na}$ ausência da política pública, o turismo se dá à revelia, ou seja, ao sabor de iniciativas e interesses particulares (CRUZ, 2002, p. 8).

Ainda na visão da autora, uma política pública de turismo pode ser entendida como: "um conjunto de intenções, diretrizes e estratégias estabelecidas e/ou ações deliberadas, no âmbito do poder público, em virtude do objetivo geral de alcançar e/ou dar continuidade ao pleno desenvolvimento da atividade turística num dado território" (CRUZ, 2002, p.41). 
Dias (2003) divide a responsabilidade do Estado sobre turismo em sete papéis distintos:

\section{Coordenação}

O Estado deve atuar como mediador de interesses procurando uma única linguagem em prol de todos os envolvidos na atividade turística e delegando, na medida do possível, essa responsabilidade a órgãos específicos. No entanto, a coordenação de implantação de uma política de turismo envolve um conjunto diversificado de atores que nem sempre apresentam identidade de interesses, e cabe ao Estado traduzir os interesses específicos num interesse geral, coletivo e que beneficie toda a comunidade.

\section{Planejamento}

O Planejamento Turístico tem como objetivo estabelecer as linhas gerais para que o desenvolvimento aconteça de modo ordenado e previamente escolhido. A ausência de tal planejamento no turismo é sentida em grande parte dos destinos brasileiros, principalmente no que diz respeito ao planejamento de longo prazo. Tem-se normalmente mediadas consideradas "paliativas" para situações emergenciais.

O Estado, enquanto representante do interesse geral, deve manter sob sua responsabilidade a definição nos rumos do desenvolvimento do país, região ou municípios, pois assim estará - pelo menos teoricamente - realizando a vontade coletiva. 


\section{Legislação e regulamentação}

As leis, decretos e resoluções são um importante instrumento para a realização das políticas públicas. Elas estabelecem regras, limites, impõem condições, barram privilégios etc. que são fundamentais para a organização turística. A elaboração de passaportes ou a criação de taxas de acesso a um recurso natural são exemplos dessa atuação do Estado.

O Estado tem papel fundamental na legislação turística em diversos setores. O desenrolar da atividade nos campos econômicos, sociais, culturais e ambientais podem ser ditados e sancionados por ele, coibindo ou estimulando atividades no espaço. Para Dias, essa regulamentação do turismo é uma das mais importantes ações que podem ser empreendidas pelo Estado em seus diferentes níveis de organização.

\section{Empreendimentos}

O Estado pode exercer uma função empresarial quando não há o interesse da iniciativa privada sobre determinada atividade, considerada fundamental e suplementar a outras que se desenvolvem em torno das atividades turísticas. O Estado pode fornecer a infraestrutura básica, como as estradas e o saneamento, mas também pode ser proprietário e dirigir empreendimentos, como hotéis, pousadas, campings etc. 
$\underline{\text { Incentivo }}$

É responsabilidade do Estado apoiar o setor privado para investimentos em determinadas regiões, por meio de incentivos, como a diminuição da carga tributária sobre determinados investimentos, isenções de taxas etc. Não se trata apenas de incentivos fiscais, mas também de apoio e divulgação da atividade turística, abertura e captação para novos empreendimentos, entre outros.

\section{Atuação social}

O Estado pode promover o turismo em camadas sociais menos favorecidas, contribuindo para a expansão da atividade e para a ampliação do exercício do direito ao lazer. Isso pode-se traduzir em um incremento no turismo social, tipo de turismo subsidiado pelo Estado ou organizações sociais com apoio do Governo.

\section{Promoção da atividade}

Para Dias, um dos papéis mais importantes do Estado está na promoção do turismo em regiões emissoras de turistas. Podem ser outros países ou mesmo outras regiões dentro de um mesmo país. A promoção do destino turístico é uma importante função do Estado, que tende a acentuar-se devido ao aumento da competição global pelo fluxo de viajantes.

A atividade turística depende de cada um dos itens acima citados para que o seu desenvolvimento possa acontecer de forma planejada, embora sabe-se que dificilmente todos estes pontos são levados em consideração quando o turismo 
instala-se na localidade. Na grande maioria dos casos, ele chega de forma espontânea, com a ausência de qualquer planejamento prévio.

Moraes (2005) nos diz que o Estado é reforçado como o principal condutor do processo de construção do país, grande fornecedor de equipamentos e construtor de espaços, sendo o primordial agente de modernização do território. E tem-se, a partir do Estado Novo, cerca de cinco décadas de realização contínua deste propósito, com a implementação progressiva de políticas territoriais cada vez mais abrangentes. Nesse movimento cresce o aparato estatal, urbaniza-se a população brasileira, forma-se uma classe média no país e organiza-se uma sociedade civil, apesar da tônica concentradora do processo de crescimento econômico, que repõe e cria acentuadas desigualdades sociais.

Vários são os problemas que podem ser causados pela atividade, caso não seja planejada e monitorada permanentemente. Dias (2003) nos aponta alguns deles: a sazonalidade (considerado um dos maiores problemas enfrentados devido à descontinuidade do fluxo turístico provocado muitas vezes por fatores climáticos ou até mesmo por períodos de férias, feriados e fins de semana), a desarticulação das atividades tradicionais, onde estas possam vir a ser subvalorizadas e até mesmo a transformação na estrutura de trabalho, quando o turismo, através da geração de novas oportunidades de empregos, desloca outros setores da economia.

Para Ruschmann (1997), no turismo cabe ao Estado zelar pelo planejamento e pela legislação necessários ao desenvolvimento da infra-estrutura básica que proporcionará o bem-estar da população residente e dos turistas. Além disso, deve zelar pela proteção e conservação do patrimônio ambiental (natural, psico-social e cultural) e criar condições que facilitem e regulamentem o funcionamento dos serviços e equipamentos nas destinações, necessários ao atendimento dos desejos dos turistas, geralmente, a cargo de empresas privadas. 
Ainda no tocante à intervenção estatal, Ferraz (1992) apud Cruz (2002), nos fala que a mesma pode estar presente em aspectos da vida social onde pode se dar sob modalidades diversas, agrupadas no que o autor chama de participação, indução e controle.

Na modalidade de "participação", o Estado exerce alguma influência econômica dentro do conjunto de atividades que definem o setor da economia. Em se tratando do setor turismo, o Estado poderia participar explorando uma companhia aérea ou um hotel, por exemplo, (FERRAZ, 1992 apud CRUZ, 2002, p.41). Essa forma de participação do Estado no setor de turismo é hoje inexpressiva no país. Salvo nos centros de convenções estaduais e num ou noutro hotel em que essa participação existe, a tendência neoliberal de anulação do Estado empreendedor faz-se bastante clara neste setor. (CRUZ, 2002, p. 41)

\footnotetext{
Em se tratando de 'indução', o Estado atua como orientador do comportamento dos agentes de mercado, em geral, pela concessão de incentivos (financeiros e fiscais) para certos investimentos. Cabe acrescentar que, no que concerne à atividade turística, essa indução pode se dar ainda pela criação de uma infra-estrutura que permita o desenvolvimento da atividade. Isto é o que vem acontecendo, por exemplo, no litoral do Nordeste. (CRUZ, 2002, p.41)
}

Por fim, na modalidade de "controle", o Estado deve atuar como regulador, estabelecendo todas as regras a serem seguidas pela iniciativa privada na condução de determinada atividade econômica. Em se tratando de Brasil "a intervenção estatal vem ocorrendo sistematicamente sob as modalidades de indução e, esporadicamente, sob a de participação" (FERRAZ,1992 apud CRUZ, 2002, p.41)

\subsection{AÇÕES DO ESTADO NO TURISMO DE PERNAMBUCO}

Uma forte característica do turismo em Pernambuco é a descontinuidade da gestão pública estadual do turismo, que tem como principais conseqüências à 
desestruturação de ações planejadas e implantadas e a falta de organização trade turístico ${ }^{4}$ e de organismos municipais.

Em 1998, durante o Governo de Jarbas Vasconcelos, foi elaborado um programa chamado de Macro Estratégia Turística para o Estado de Pernambuco, documentos norteador contendo ações e diretrizes para o desenvolvimento do turismo para o estado.

Em se tratando de iniciativas da Secretaria de Turismo do Recife, entre 2007 e 2008 foi criado o programa "Ano do Turismo em Recife", cuja finalidade foi promover entretenimento aos turistas que visitavam a cidade com programações diárias de apresentações culturais e artísticas em pontos turísticos, além de procurar estruturar novos equipamentos turísticos.

No mesmo período, o projeto intitulado "Turismo na Comunidade", procurou descentralizar o turismo da praia de Boa Viagem por meio da valorização de equipamentos existentes em outras localidades e descoberta de novos potenciais.

Dez anos após essa iniciativa do Governo em elaborar a Macro Estratégia, foi criado um planejamento estratégico para o desenvolvimento da atividade, lançado em meados do ano de 2008, com prazo de ação entre 2008 a 2020 e que intitulado "Pernambuco para o mundo".

Para delinear pólos que serão foco prioritário dos programas e ações propostos nesta Estratégia, foi considerada a amplitude do Plano (2008-2020), o nível de

${ }^{4}$ Entende-se por trade turístico como sendo as áreas econômicas envolvidas nas prestações de serviços para atender as necessidades comuns de todos os turistas: meios de hospedagem, transportadores, agentes de viagens e turismo, organizadores de eventos, entre outros. (Duarte, 2005) 
desenvolvimento turístico dos destinos ${ }^{5}$ e a potencialidade de cada um deles, conforme será visto com maior detalhe abaixo.

Ficaram definidas, assim, as seguintes áreas prioritárias para o desenvolvimento do turismo em Pernambuco, de acordo com os níveis de desenvolvimento que seguem (Mapa 1):

\section{Nível de desenvolvimento l:}

Destinos turísticos já consolidados no Estado de Pernambuco, mas que precisam ser aprimorados. São atualmente os grandes destinos turísticos do Estado, mas apesar disso, apresentam sérios problemas estruturais, tanto com relação à infra-estrutura básica, quanto à de apoio dentre outros. Estes destinos serão priorizados nas ações de curto prazo, já que possuem altos níveis de visitação e são responsáveis pela manutenção de Pernambuco no mercado turístico, e também em função disso, podem rumar à saturação e decadência. Estão nesse nível de desenvolvimento: Ipojuca (especialmente o distrito de Porto de Galinhas), Fernando de Noronha e os principais municípios da Região Metropolitana de Recife (Recife, Olinda e Jaboatão dos Guararapes).

Nível de desenvolvimento II:

Constituído por áreas que possuem grande potencial, como importantes destinos turísticos para o estado. Algumas destas já recebem um fluxo de turistas considerável, especialmente ao longo da

${ }^{5}$ São considerados destinos turísticos o país, região ou cidade para onde se dirigem os visitantes, tendo-os como principal objetivo. (BULL,1994) 
temporada de verão. São destinos majoritariamente de sol e praia, segmento de grande destaque em Pernambuco, mas que também agregam elementos de apelo natural e/ou cultural, porém ainda sem estruturação. São destinos que se situam neste nível de desenvolvimento: municípios do Litoral Norte/Mata Norte de Pernambuco (Goiana, Igarassu, Itamaracá, Itapissuma, Paulista, Vicência, Nazaré da Mata, Carpina, Tracunhaém, Paudalho, Lagoa do Carro); e do Litoral Sul (Cabo de Santo Agostinho, Sirinhaém, Rio Formoso, Tamandaré, São José da Coroa Grande, Barreiros).

Nível de desenvolvimento III:

Composto por destinos que já têm algum fluxo turístico e apresentam potencial turístico, mas que não possuem um desenvolvimento organizado. São destinos que atraem um fluxo majoritariamente local e/ou regional, mas que tem potencial para se consolidar junto a este público e, eventualmente, até mesmo atingir público nacional/internacional. O tipo e o nível de desenvolvimento destes municípios são bastante diversos, inclusive em função do tipo de atratividade de cada um deles, indo desde segunda residência até negócios. Entretanto, todos têm em comum a necessidade de uma grande estruturação, tanto em termos de estrutura física e desenvolvimento de atrativos, quanto em termos de organização estratégica. As áreas que englobam este nível de desenvolvimento são: municípios do Agreste (Caruaru, Gravatá, Garanhuns, Bezerros, Bonito, Brejo da Madre de Deus) e Petrolina.

Nível de desenvolvimento IV:

Composto por localidades com restrito desenvolvimento e/ou estruturação do turismo, mas que possuem uma atratividade 
considerável para um público majoritariamente regional e local. São áreas com necessidades básicas de infra-estrutura e também de estrutura de apoio para o desenvolvimento do turismo. Por sua relevância para o incremento do turismo doméstico no estado de Pernambuco e pelas ações necessárias, são áreas que devem começar a ser desenvolvidas dentro do período de execução deste Plano. Encontra-se neste nível de desenvolvimento: municípios do Agreste (Buíque, Pesqueira, Arcoverde) e o Sertão (Triunfo e Serra Talhada).

Nível de desenvolvimento V:

Esta categoria engloba destinos que possuem algum potencial turístico, mas não apresentam qualquer tipo de desenvolvimento e/ou estruturação do setor. São destinos que não apresentam condições de serem desenvolvidos durante o período de execução deste Plano, devendo, entretanto, serem considerados como pontos de investimento da ação do poder público futuramente, por serem importantes elementos complementares ao setor turístico do Estado de Pernambuco. Encontram-se neste nível de desenvolvimento: São José do Belmonte, Santa Cruz da Baixa Verde, Afogados da Ingazeira, São José do Egito, Bom Conselho, Saloá, Belo Jardim, Poção, Taquaritinga do Norte, Santa Cruz do Capibaribe, Toritama, Moreno, Camaragibe, Quipapá, São Benedito do Sul, Palmares, Santa Maria da Boa Vista e Lagoa Grande. 
$-40$

$-38$

$-36$

$-34$

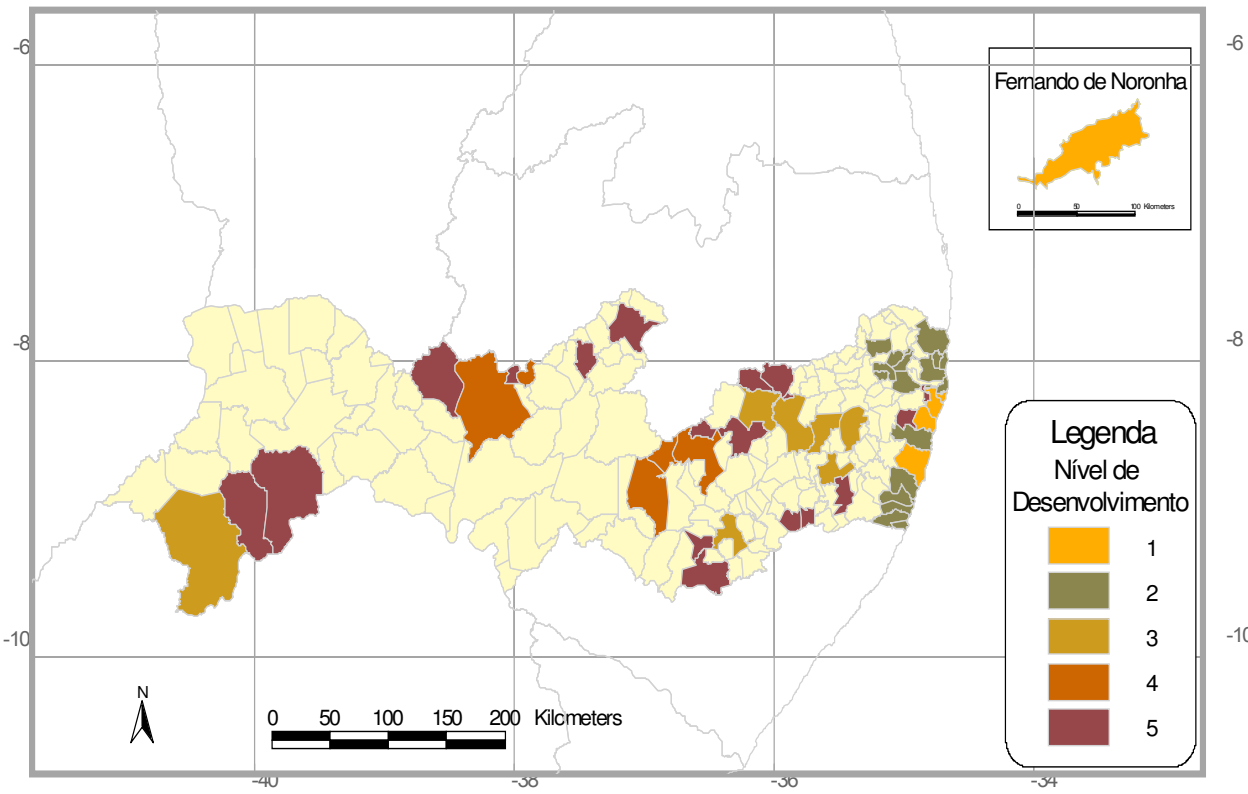

Mapa 1 - Municípios do Estado de Pernambuco que fazem parte do Planejamento Estratégico

Percebe-se claramente nessa divisão que os municípios litorâneos têm prioridade nos investimentos, visto que os mesmos já possuem vocação natural ${ }^{6}$ para o turismo assim como, também infra-estrutura turística e de apoio mesmo que não satisfatória na sua localidade.

É no espaço que o poder ganha visibilidade, às vezes de forma mascarada e outras como uma forma explícita de dominação, se tornando então um espaço manipulado ora pelo Estado e outras vezes pelas operadoras de turismo e empresários locais. No turismo, as cidades e as paisagens são transformadas em atração turística e, por conseguinte, em mercadoria manipulada pelos agentes hegemônicos.

${ }^{6}$ Diz-se que um município possui vocação natural para o turismo quando o mesmo reúne características naturais (por exemplo, praias, parques, esculturas naturais, entre outros) que despertem o interesse em visitá-lo mesmo sem grandes divulgações e/ou incentivos. 
A atuação do poder estatal implica necessariamente em uma série de ações referenciadas ao espaço (distribuições, repartições, divisões, interdições, etc.), tendendo a torná-lo o principal agente de sua valorização logo, da formação territorial (MORAES, 2000).

A ação do Estado acaba por, muitas vezes, fragmentar o espaço, criando novas centralidades e até mesmo um espaço de dominação, isso se dá, em grande parte, devido à ação de empreendedores imobiliários e do processo de mercantilização do mesmo do espaço turístico.

Para Moraes (1988), as formas espaciais produzidas pela sociedade manifestam projetos, interesses, necessidades, utopias. São projeções dos homens (reais, seres históricos, sociais e culturais), na contínua e cumulativa antropomorfização ${ }^{7}$ da superfície terrestre. Esta apropriação implica determinações estritamente econômicas. Ninguém irá negar que a organização dos lugares obedece a funções e necessidades da produção, que a disposição dos objetos responde a imperativos técnicos, que os padrões espaciais do capitalismo revelam a ânsia do lucro.

O espaço constantemente produzido é fruto da ação do homem sobre a superfície da Terra e que reflete, a cada momento, as relações sociais que the deram origem. Sendo assim, esta produção social do espaço expressa, pelas suas representações, a relação que os homens estabelecem no mesmo.

Para Nicolás (1996) apud Cruz (2002), o turismo concorre no processo de transformação dos territórios para seu uso, com outros usos do território, bem como as formações socioespaciais precedentes a seu aparecimento. Apesar desses confrontamentos, a força do turismo é dada por sua capacidade de criar, de

\footnotetext{
${ }^{7}$ Lukács (1976) entende a antropomorfização como o processo em que os homens dão forma humana àqueles fenômenos da causalidade natural (ou mesmo da causalidade sócio-histórica) que não consegue explicar.
} 
transformar e, inclusive, de valorizar, diferencialmente, espaços que podiam não ter valor no contexto da lógica de produção.

Com a chegada do turismo nas localidades, normalmente ocorre um processo acelerado de valorização das terras e de especulação imobiliária, além do que a instalação das grandes redes hoteleiras causa profundas transformações na localidade receptiva.

Em Pernambuco, um dos exemplos mais visíveis do que foi dito está na praia de Muro Alto, no município de Ipojuca, que concentra os maiores e melhores hotéis do Estado (Foto 1). Após a chegada dessas novas redes hoteleiras, ocorreu uma supervalorização das terras, além de mudança nos hábitos das pessoas que normalmente freqüentavam a referida praia, visto que mesmo de forma "discreta" houve uma "delimitação" no uso do espaço para o lazer.

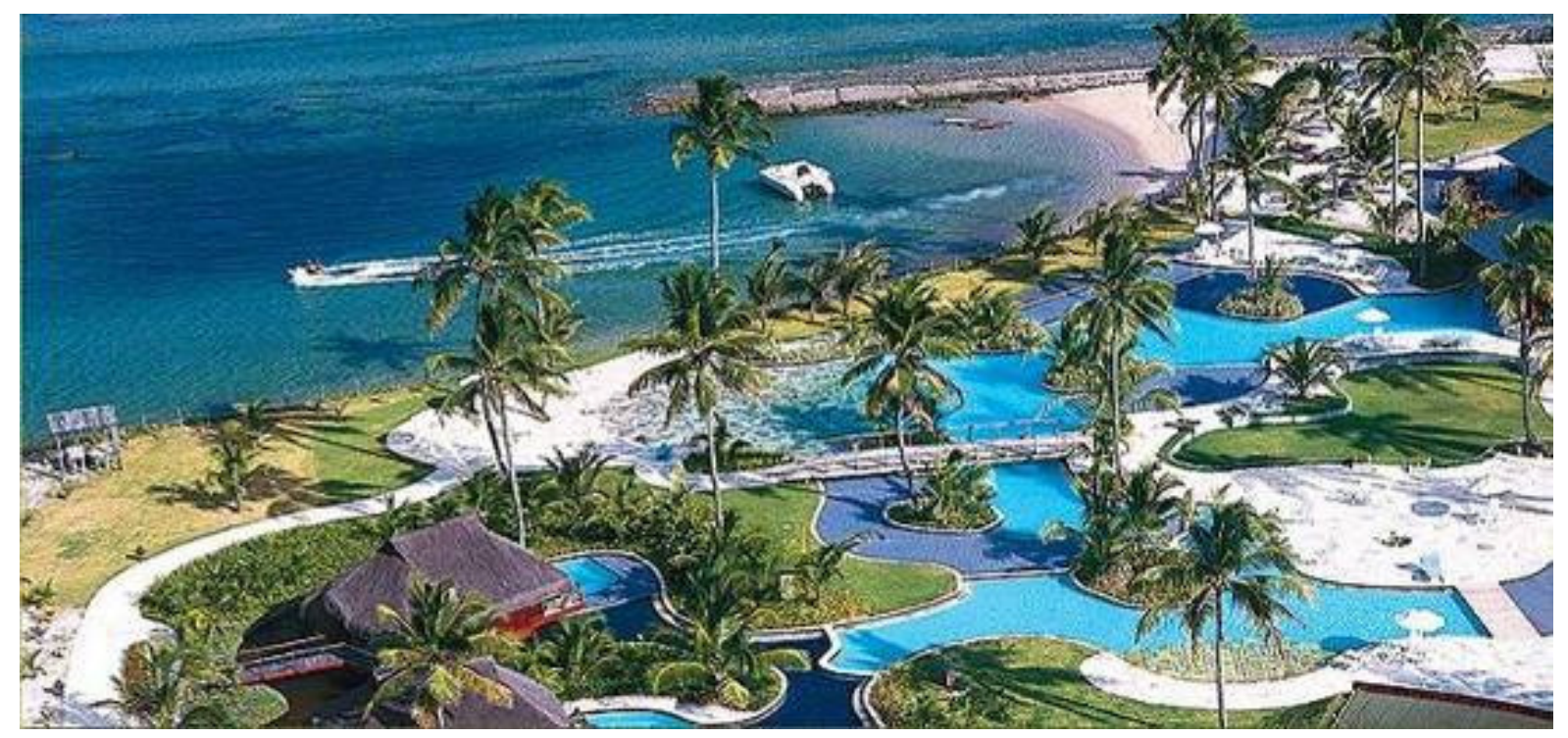

Foto 1- Vista aérea - Nannai Resort, em Muro Alto (Fonte: www.nannai.com.br)

Os impactos das profundas transformações ocorridas no território advinda das grandes redes hoteleiras são segundo Prosérpio (2003) apud Cruz (2005): 
- Transformações organizacionais e introdução de nova cultura, novos conceitos, paradigmas e valores; produção em massa versus flexível;

- Introdução de métodos de gerenciamento "toyotistas", cooperação gerente-trabalhadores, mão-de-obra multifuncional, controle de qualidade total e redução de incertezas;

- Necessidade de novos investimentos em reformas, modernização e ampliação;

- Estratégia de segmentação de mercado e disseminação das "marcas";

- Foco na gestão hoteleira e na diminuição dos investimentos imobiliários; adoção de sistemas flexíveis de financiamento do imobilizado e parecerias;

- Disseminação do conceito de empresa horizontal e ênfase na capacitação de mão-de-obra: profissionalização da gestão;

- Formação e fortalecimento de redes e alianças estratégicas;

- Fortalecimento dos meios de hospedagem de pequeno e médio porte, praticantes de estratégias diferenciadoras; e

- Diminuição da importância dos sistemas oficiais de classificação hoteleira e outros regulamentos de regulação. 
Os atores mais poderosos se reservam os melhores pedaços do território e deixam o resto para os outros e nesse movimento de apropriação, tudo que existia anteriormente à instalação dessas empresas hegemônicas é convidado a adaptar-se às suas formas de ser e de agir, mesmo que provoque, no entorno preexistente, grandes distorções (SANTOS, 2006).

Conforme dito anteriormente, foi assim no município de Ipojuca, onde as grandes redes hoteleiras elegeram os melhores pedaços desse território para se instalarem e impor suas lógicas e ritmo de crescimento. Tal explicação condiz com a fala de Santos, quando ele afirma que nesse movimento, tudo que existia anteriormente à instalação dessas empresas hegemônicas é convidado a adaptar-se às suas formas de ser e de agir.

Com o objetivo de intensificar o uso turístico de seus territórios, os governos dos estados nordestinos, respaldados pelo poder público federal, instituíram nas últimas décadas duas políticas regionais para a atividade. Uma delas é a Política de Megaprojetos Turísticos ${ }^{8}$, a outra é o Programa para o desenvolvimento turístico do Nordeste Prodetur-NE. A primeira objetiva ampliar a infra-estrutura regional, enquanto a segunda visa melhorar aspectos da infra-estrutura básica e de acesso e aperfeiçoar o sistema institucional de gestão da atividade. Ambas estão impingindo significativas transformações ao processo de construção e reconstrução do espaço no litoral nordestino, por meio do (re)ordenamento de territórios para uso do turismo. (CRUZ, 2002, p.77)

O megaprojeto turístico Costa Dourada abrange territórios de dois Estados: Pernambuco e Alagoas. Foi idealizado em 1990, quando uma ação conjunta entre o governo federal e os governos daqueles Estados, propôs ao Banco Interamericano de Desenvolvimento - BID o financiamento de um programa visando o aproveitamento turístico de um trecho de costa entre Recife e Maceió. (CRUZ, 2002, p.100)

${ }^{8}$ Um mega projeto turístico é "uma fórmula de desenvolvimento que consiste na realização de um projeto integralmente planejado, dentro de um centro turístico já existente, e que representa a preparação de uma oferta importante de terrenos turísticos de primeira qualidade, que se oferece à inversão privada, para que esta desenvolva, de forma garantida, a infra-estrutura e a superestrutura, fortalecendo a imagem e a identidade desse centro turístico". (BLANCO, 1992 apud CRUZ, 2002, p. 78, 79) 
As diretrizes gerais do projeto Costa Dourada, adequadas à sua concepção inicial, previam dois setores diferenciados de intervenções: o corredor turístico, delimitado especialmente em cerca de $120 \mathrm{~km}$ de litoral entre as cidades de Recife e de Maceió e os centros integrados de turismo, espaços restritos cuja proposta era fundar áreas planejadas exclusivamente para a atividade turística. (LIMA, 2006)

Ainda segundo a autora, no que se refere à criação de centros integrados de turismo, o Governo de Pernambuco concebeu, em 1993, o Centro Turístico de Guadalupe como área prioritária de investimentos. Este centro foi formado pelos municípios de Rio Formoso, Sirinhaém, Tamandaré, e tinha como objetivo promover a ordenação da orla marítima, associado à exploração turística à manutenção dos ecossistemas costeiros, especialmente os manguezais.

O PRODETUR-NE (Foto 2), programa de cunho desenvolvimentista que, busca favorecer o desenvolvimento da região nordeste, na sua primeira fase em Pernambuco onde foram selecionados sete municípios para serem contemplados com os projetos, sendo estes: Recife, Olinda, Paulista, Ipojuca, Rio Formoso, Sirinhaém e Tamandaré. 


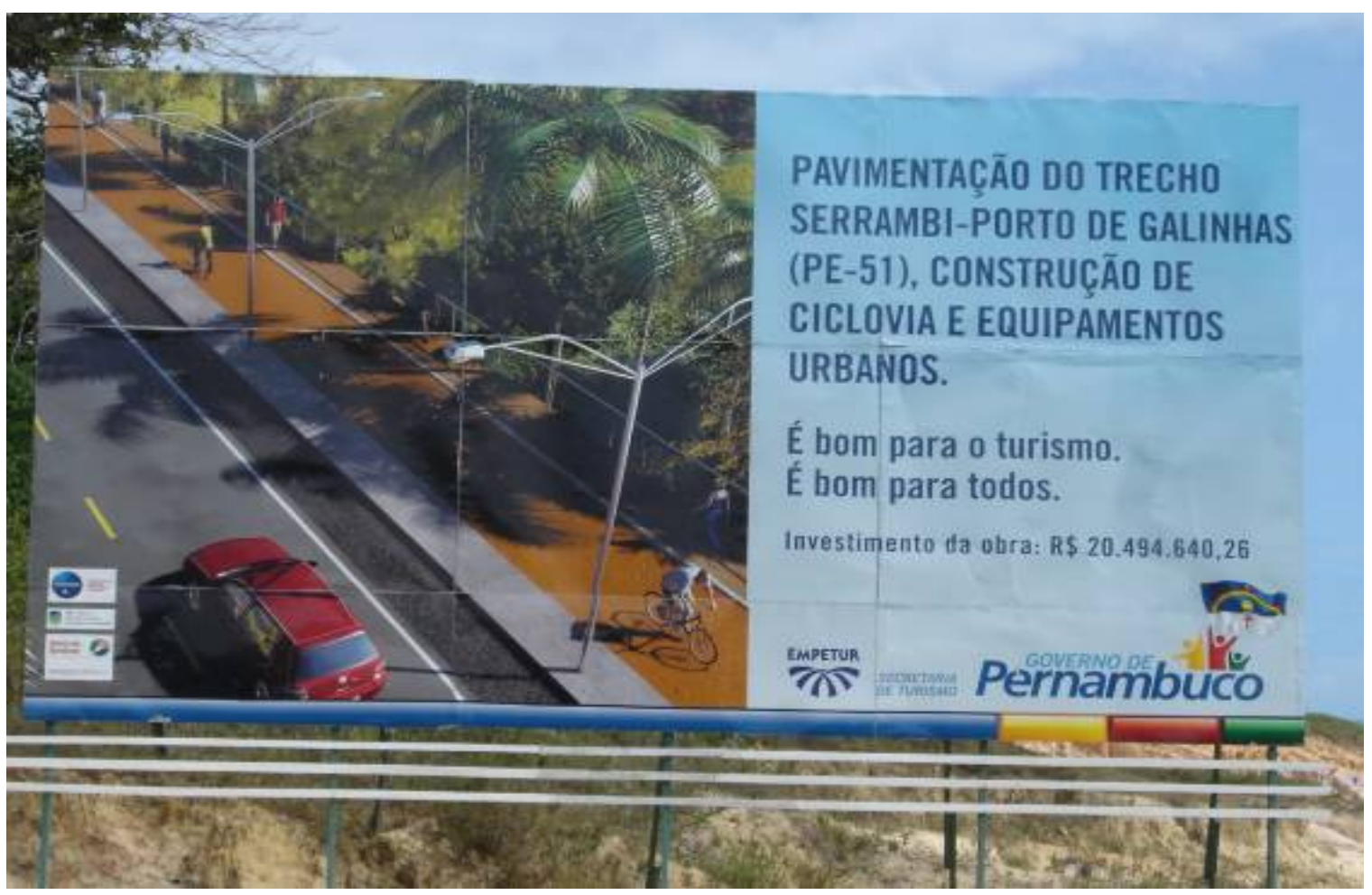

Foto 2 - Obra financiada pelo PRODETUR-NE (Fonte: Autora, 2008).

O PRODETUR-NE, criado pela Sudene e pela Embratur - Portaria Conjunta 1, de 29 de novembro de 1991 -, abarca todos os estados nordestinos e a região norte do Estado de Minas Gerais. (CRUZ, 2002, p.111)

O PRODETUR-NE, na sua origem, teve como objetivos específicos:

Aumentar o turismo receptivo; aumentar a permanência do turista no Nordeste; induzir novos investimentos na infra-estrutura turística, gerar emprego e renda com a exploração direta ou indireta da atividade turística (Portaria Conjunta 2 de 16 de abril de 1993, instituída pelos Ministérios da Fazenda, da Indústria, do Comércio e do Turismo, da Integração Regional, da Aeronáutica, e pela Secretaria de Planejamento, Orçamento e Coordenação da Presidência da República) (CRUZ, 2002, p.111).

A proposta do PRODETUR-NE II, assinado no ano de 2002, ao ser criado, teve como função expandir e complementar as obras já iniciadas no PRODETUR-NE I, integrando as iniciativas públicas e privadas, dando ênfase na preparação e expansão dos produtos turísticos regionais. 
Os empreendimentos turísticos viabilizados pelas políticas de megaprojetos e PRODETUR, sejam nacionais ou internacionais, geram empregos e vêm muitas vezes acompanhados também da implantação de uma infra-estrutura que, de algum modo, beneficia comunidades locais, como a infra-estrutura de saneamento básico ou a ampliação e melhoria de vias de acesso. Os novos objetos (infra-estrutura suporte e turística) e fluxos (de pessoas, de informação, de capital) trazidos pelo turismo para essas localidades podem significar um dinamismo favorável à economia local e/ou regional, dependendo do grau de interação que os empreendimentos implantados e a implantar estabeleçam com o seu entorno e da forma como os poderes públicos locais conduzam essa interação (CRUZ, 2002).

Na execução do processo de planejar e na tomada de decisões, é importante que todos os envolvidos com a atividade turística considerem os elementos e fatores, favoráveis e desfavoráveis às localidades e suas comunidades, visto que influenciam diretamente 0 tipo de turismo, a ser implementado e, quando negligenciados, podem repercutir negativamente sobre a gestão administrativa. No processo de planejamento turístico, considera-se a participação dos atores sociais indispensável ao pleno desenvolvimento local (FIRMINO, 2006, p. 58).

A Tabela 1 ressalta os interesses e necessidades dos atores sociais envolvidos na atividade turística.

Tabela 1 - Necessidades e visões dos diferentes atores sociais (Fonte: Adaptado de FIRMINO, 2006, p.61)

\begin{tabular}{|c|c|}
\hline ATORES & NECESSIDADES E INTERESSES \\
\hline Governo Local & - Projetar o município como destino turístico \\
& - Incrementar a arrecadação e circulação de renda \\
\hline Setor Privado & - Oportunidade econômica \\
\hline
\end{tabular}




\begin{tabular}{|c|l|}
\hline & - Infra-Estrutura, facilidades e acessos \\
& - Atrativos em quantidade e qualidade \\
\hline Comunidade & - Saúde, Trabalho, Educação e saneamento \\
& - Respeito aos seus direitos e suas tradições \\
& - Participar das tomadas de decisões \\
\hline Turista & - Preço, conforto e segurança \\
& $\begin{array}{l}\text { - Qualidade nos serviços e na experiência da } \\
\text { visitação }\end{array}$ \\
\hline
\end{tabular}

No que diz respeito ao Governo local, as responsabilidades desse ator já foram discutidas anteriormente. Já no tocante ao setor privado, o mesmo tem grande papel no desenvolvimento da atividade turística, como, por exemplo, através de estímulos ao treinamento e capacitação dos seus funcionários, colaborando na construção de novas estradas, implantando infra-estrutura turística com qualidade e inserindo a comunidade nos seus projetos em conjunto com poder público.

A comunidade participa nesse processo desde o recebimento e acolhimento aos turistas, como também no usufruto de algumas conquistas como é o caso de implantação de novos hospitais, caixas eletrônicos, bares e restaurantes e na participação das tomadas de decisões em reuniões de planejamento para o turismo na localidade. Já o turista necessita que sejam adotados preços justos, serviços prestados com qualidade e em contrapartida deve haver comprometimento e respeito às tradições da localidade a qual ele está visitando.

Cada processo de ocupação e transformação do espaço pela atividade turística tem a participação dos diversos atores envolvidos de forma diferenciada, variando de acordo com seus costumes e sua história. Em Pernambuco, a ocupação da zona costeira e a chegada do turismo merecem destaque na seção a seguir. 


\section{O PROCESSO DE OCUPAÇÃO DO LITORAL PERNAMBUCANO}

Esta seção enfatiza o processo de ocupação do litoral do Estado de Pernambuco e aborda os conceitos de zona costeira. As segundas residências e sua influência na história dessa ocupação também são referenciados no trabalho. Autores como Marc Boyer, Rita Araújo, Clarisse Lima e Antônio Madruga ajudam nesse processo da construção do entendimento. 


\title{
3.1 A ZONA COSTEIRA DE PERNAMBUCO E O PROCESSO DE OCUPAÇÃO DO LITORAL
}

Primeiramente faz-se necessário definir o conceito de Zona Costeira que, segundo o PNGC - Plano Nacional de Gerenciamento Costeiro ${ }^{9}$ é o espaço geográfico de interação do ar, do mar e da terra, incluindo seus recursos ambientais, abrangendo as seguintes faixas: a marítima onde se compreende que se estende mar afora distando 12 milhas marítimas das Linhas de Base estabelecidas de acordo com a Convenção das Nações Unidas sobre o Direito do Mar, compreendendo a totalidade do Mar Territorial e a Terrestre, faixa do continente formada pelos municípios que sofrem influência direta dos fenômenos ocorrentes na Zona Costeira.

Moraes (1999) identifica então dois elementos como essenciais na delimitação da zona costeira: as divisões político-administrativas, destacando-se o município como espaço de planejamento, ação política e o padrão predominante de uso do solo que atua como "fator econômico qualificador dos lugares".

Para Carvalho (1994) apud Farias (2002, p.32), a zona costeira pode ser definida como:

\begin{abstract}
Uma faixa de interação entre o mar e a terra e por isso deve incorporar uma faixa continental e as terras submersas da plataforma continental e águas que se encobrem. [...] Zona costeira é parte da abrangência dos efeitos naturais resultantes das interações terra-mar-ar, levando em conta a paisagem físicoambiental em função dos acidentes topográficos situados ao longo do litoral, como ilhas, estuários e baías, comporta em sua integridade os processos e interações características das unidades, ecossistêmicas litorâneas e inclui as atividades sócio-econômicas que aí se estabelecem.
\end{abstract} 10hs.

9 http://www.mma.gov.br/estruturas/orla/_arquivos/pngc2.pdf, acessado dia 13/02/2009 às 
Ainda segundo o autor, a zona costeira brasileira é formada por meios marinhos, terrestres e atmosféricos, destinados a múltiplos usos por diversas atividades salientando-se o seu valor econômico, ambiental e paisagístico. As áreas litorâneas caracterizam-se pela presença de ecossistemas estuarinos, manguezais, praias, costões rochosos, dunas, recifes de corais, arenitos, lagunas e baías. As bacias hidrográficas, matas costeiras, restingas e dunas constituem os ecossistemas ambientais relevantes ao meio marinho (FARIAS, 2002).

Devido aos seus ecossistemas constituídos por estuários, manguezais (Foto 3), praias, costões, dunas, recifes de corais, arenitos e lagunas costeiras, as áreas costeiras possuem um valor econômico, paisagístico e ambiental peculiar.

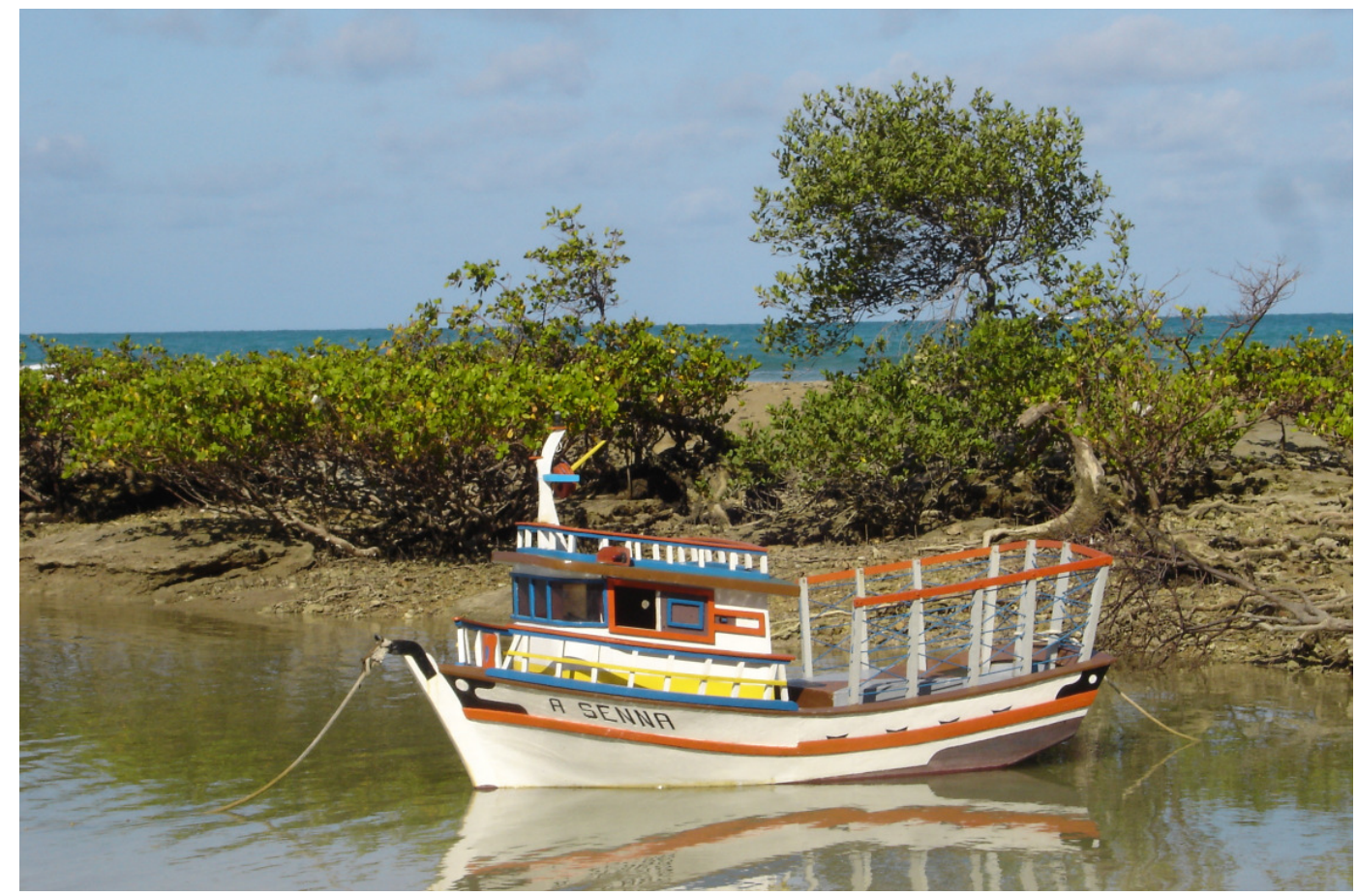

Foto 3 - Manguezal na Praia dos Carneiros, Litoral Sul do Estado (Fonte: Autora, 2008)

O interesse pelo litoral acompanhou a descoberta das virtudes da água do mar. Fonteles (2004) apud Lima (2006) remonta essa descoberta ao povo europeu que, esperava que o mar acalmasse as ansiedades e corrigisse os efeitos perversos da civilização urbana, prática muito comum ainda nos dias de hoje. A ausência de propriedades à beira-mar remetia os visitantes a uma sensação de igualitarismo, fato 
inexistente nos centros urbanos. O pobre misturava-se com o rico que, por distração ou diletantismo, participava da coleta do peixe e de outros animais marinhos.

Entre o século XVIII e a primeira metade do século XIX, constatou-se o despertar do interesse coletivo pelas praias e a contemplação da beleza do oceano. la-se à praia mais para observar as imagens registradas em pinturas de museus, do que para se banhar. Por volta de 1750 registrou-se um fluxo de pessoas à busca de cura nas praias, preocupadas com o ambiente, com orientações higiênicas, misturando-se cuidados corporais a uma terapia do espírito. (FONTELES, 2004 apud LIMA, 2006)

No século XIX, o modelo de banho de mar terapêutico não sofreu grandes alterações em relação ao período anterior. O mar, por suas tantas virtudes tonificantes, recebeu em seu meio líquido os doentes linfáticos, os que sofriam do sistema neurovegetativo, os escrofulosos e enfraquecidos de um modo geral: crianças raquíticas, jovens cloróticas, mulheres estéreis e as que possuíam ciclo menstrual desregulado. Acreditava-se o mar particularmente eficaz no combate às neuroses. Com o passar dos anos, vieram as virtudes curativas e higiênicas do ar marinho e dos raios de sol, desde que experimentados até as dez horas da manhã. Por fim, após longo tempo de resistência, instalou-se a moda dos banhos nas praias do Mediterrâneo, acompanhando a literatura médica adepta aos banhos mornos e quentes e a admiração dos viajantes pela transparência das águas dos mares gregos e italianos (ARAÚJO, 2007, p. 170).

Boyer (2003) ratifica a idéia de que a massificação do turismo surgiu entre o século XVIII até início do XX através do discurso terapêutico-higienista, enfatizado no século XIX, de que locais como o mar e as montanhas são eleitos para os tratamentos. $O$ autor ressalta que 0 amor pelo campo, se tornara lúdico e que a transformação das práticas populares de uso das águas no termalismo mundano das estações termais se estendeu até os balneários oceânicos.

Houve, a partir de 1820, um estímulo ao turismo em grupo ao longo do litoral, marcado pelo engajamento do corpo e pela exaltação do prazer advindo desse novo tipo de prática relativa ao contato com a natureza. 
O poder público, a partir do século XVIII demonstrou um forte interesse pelas construções à beira-mar, já percebendo uma vocação ao lazer e ao turismo, sendo datado dessa época o início das primeiras estações balneárias alemãs, inglesas e francesas.

Para o autor Urry (1996) apud Lima (2006, p.74):

A grande melhoria dos meios de transporte, em especial a abertura de estradas de ferro, foi uma condição a mais para o crescimento do turismo de massa nos balneários. As companhias de estradas de ferro acreditavam que o tráfego durante as férias era indício de que se tratava de um negócio particularmente lucrativo.

Mais recentemente, a partir da década de 1930, o mar reapareceu com suas características completamente modificadas e diferenciadas das dos séculos anteriores. Iniciou-se um novo tipo de banho que foi denominado "banho batido". Tais características tiveram início nos balneários europeus, como Deauville, Biarritz e Trouville na França, e posteriormente se expandiram para a América do Sul em Viña Del Mar no Chile, em Punta Del Este no Uruguai, e finalizando no Rio de Janeiro: nas praias do Leme, Copacabana e Ipanema (LINHARES, 1992).

Urry (1996) apud Lima (2006, p.74) ressalta que:

No período pós-guerra, era o sol, e não o mar, que, supostamente, proporcionava saúde e atração sexual, dessa forma, muitos pacotes turísticos o apresentavam como motivo para viajar durante as férias. Assim, os balneários do norte da Europa passaram a ser considerados menos "na moda", o que beneficiou enormemente 0 desenvolvimento de balneários em torno do Mediterrâneo.

Os colonizadores que chegaram aqui no Brasil traziam uma série de comportamentos e preconceitos em relação aos espaços litorâneos. Procuravam ocupá-los segundo aspectos relativos à segurança, instalando-se em fortins e cidadelas juntos aos portos que representavam as seguranças de defesa. 
As vias de circulação construídas com a expansão da cana-de-açúcar nas regiões dos tabuleiros costeiros, fizeram com que os acessos as diversas praias do litoral, deixassem de serem estradas de contrabando ou de aventureiros. Com o acesso mais fácil, rapidamente as vilas de pesca foram se transformando em balneários; esta transformação faz surgir os primeiros elementos da especulação, os loteamentos que nestes primeiros momentos servem para reforçar o poder local, principalmente do detentor de terras provocando um enorme crescimento urbano, totalmente desordenado e confuso, sem nenhuma infra-estrutura básica.

Para Madruga (1992) existem dois modos de ocupação do litoral que se confrontam: a ocupação "natural" ou "tradicional" e a ocupação "artificial" ou "moderna".

A ocupação 'natural' é aquela constituída pela população permanente (nativa), de raízes estabelecidas há muito tempo, com várias gerações que se sucederam na área, de origem geralmente camponesa é formada principalmente por lavradores, pescadores, pequenos comerciantes ou empresas familiares de manufaturas artesanais, ou semi-artesanais, bem como pessoal do setor terciário (funcionários público civis ou militares subordinados aos governos municipais, estaduais ou federais, funcionários dos serviços de saúde, polícia, fiscalização e arrecadação de impostos, correios, entre outros.), as vezes recrutados entre os membros da própria população permanente. (MADRUGA, 1992, p.26)

Ainda para o mesmo autor, a ocupação "moderna" que tem uma tendência a aumentar, atualmente é constituída por empresários ou funcionários de firmas comerciais ou industriais com sede no interior do país, bem como funcionários públicos dos governos estaduais ou federais, tanto do setor administrativo, como técnico, para a direção dos serviços de saneamento, energia elétrica e órgãos de pesquisas diversas. $O$ autor ainda ressalta que deve-se também mencionar uma população flutuante de veranistas (que alugam ou adquirem casas de moradia intermitente e turistas que utilizam hotéis, pensões e clubes náuticos).

Madruga (1992) fala também sobre as várias "pressões" que o litoral sofre. Para o autor, em primeiro lugar existe a pressão de tipo industrial, proveniente da renovação da economia marítima, ligada à utilização da água, fonte de energia ou 
fonte de arrefecimento para certos tipos de indústrias: a indústria pesada; centrais térmicas e centrais nucleares.

Em segundo lugar neste processo outra pressão proveniente da modernidade - a atividade turística. Ele acredita que em decorrência da concentração de pessoas na cidade, da poluição e da necessidade de um contato maior com a natureza, do mar, ocorre no período de férias afluências para lugares com essas características. Para isso, necessita-se de implantação de infra-estruturas rodoviárias, comerciais, de recreio, entre outros.

Em terceiro lugar, para o referido autor, tem-se outro fenômeno da modernidade: a urbanização. Este ligado fortemente em suas causas aos dois outros anteriores. Isto porque os mesmos motivos que provocaram o início da pressão turística provocaram a busca do litoral para moradia. $O$ desejo de natureza de espaço (imensidão) de lazer e de liberdade levou os homens em direção ao litoral como turistas e provocando-os a desejarem instalarem-se nas cidades próximas ao litoral transformando-as pelo seus hábitos e economia, sendo o início do processo de litoralização efetiva. Este fato associado a crescente industrialização e o desenvolvimento paralelo de serviços criaram oportunidades de emprego, ocasionando uma intensificação da urbanização ao longo da costa.

No que se refere aos modelos de urbanização no litoral a estetização e estandardização de linhas de beira-mar (muitos similares em localidades por vezes muito distantes umas das outras), os condomínios fechados de alto padrão e, mais recentemente, como uma clara tendência nacional, os resorts, a maioria deles pertencentes a bandeiras nacionais (CRUZ, 2007, p.54).

No estado de Pernambuco, pode-se perceber a ocorrência desses três tipos de modelos. 


\subsection{A OCUPAÇÃO DO LITORAL EM PERNAMBUCO}

A autora Rita Araújo, no seu livro sobre a história de como se desenvolveu o processo de ocupação do litoral de Pernambucano, intitulado: As praias e os dias: história social das praias de Recife e Olinda nos diz que:

Para Pernambuco, os primeiros sinais de efetiva mudança tornaramse evidentes a partir do início da década de 1840, quando os médicos começaram a recomendar uso terapêutico das águas do mar à população e surgiu a barca de banhos salgados na foz do rio Capibaribe. Entre o final do século XIX e primeiros decênios do XX, as transformações referidas mostraram-se mais intensas $e$ generalizadas, resultando na consolidação de uma determinada forma predominante da coletividade usufruir praias e mares. (ARAÚJO, 2007, p.14)

No ano de 1537, Duarte Coelho, então governador da Capitania de Pernambuco, elaborou o documento de "doação" chamado Foral de Olinda e fez distribuição de porções de terras para compor o patrimônio de Olinda, sede da capitania, para a Câmara, assim como também para uso de seus moradores, uso este que era regulado através de regras sociais, jurídicas e econômicas. (ARAÚJO, 2007)

Ainda segundo Araújo (2007) no correr dos séculos, especialmente após a ocupação holandesa em Olinda e seus revezes sofridos pela cidade em decorrência disso, muitas das terras que foram doadas à Câmara através do Foral de Olinda e das terras destinadas ao uso público e ao bem comum haviam sido indevidamente ocupadas por terceiros, em parte por não haver clareza nas demarcações explicitadas no documento, segundo a justificativa dos vereadores.

Ao confirmar o referido documento por provisão régia, em 1678, o rei o fez com restrições, mantendo apenas os bens que estavam de posse da câmara. Aqueles que estavam em mãos de terceiros deveriam ser requeridos por via judicial. (ARAÚJO, 2007, p.36)

A pesca também teve importante papel na fixação do homem no litoral Pernambucano, com o intuito de comercializar o pescado entre os séculos XVI até 
pelo menos o XIX. A intensificação da ocupação intensificou-se no século XVIII que Câmara Cascudo $^{10}$ chamou de "século do povoamento nordestino", através da pescaria, do transporte de sal, de correspondências, entre outros.

A partir da última década do século $X X$, com apoio integrado do Estado e de órgãos internacionais, instalou-se no litoral nordestino um processo de implantação de empreendimentos turísticos nas modalidades do turismo global, apropriando-se de lugares considerados "nobres" e, conseqüentemente, desapropriando comunidades tradicionais. Dessa forma, são produzidas formas elitistas de ocupação, desenrolando-se uma luta de interesses pelo espaço: uns buscando acumular lucros, e outros, as condições básicas de sobrevivência (MENDES ET AL., 2004 apud LIMA, 2006, p.77)

Pernambuco possui $187 \mathrm{~km}$ de extensão de litoral abrangendo vinte e um municípios, constituindo o mais relevante aglomerado populacional do Estado, o que resulta em uma grande e variada forma de exploração e ocupação. Possui uma faixa litorânea que se estende de Goiana ao Norte, no limite com o Estado da Paraíba, até o município de São José da Coroa Grande, ao sul, na divisa com o Estado de Alagoas.

O litoral Pernambucano foi dividido pela CONDEPE/FIDEM - Agência Estadual de Planejamento e Pesquisa do Estado de Pernambuco e pela SEPLANDES Secretaria de Planejamento de Desenvolvimento Social (1999), em três setores: $1^{\circ}$ Setor - Litoral Norte, abrange os municípios de Paulista, Abreu e Lima, Igarassu, Itapissuma, Ilha de Itamaracá e Goaiana; o setor 2o- Núcleo Metropolitano, Olinda, Recife e Jaboatão dos Guararapes constituem o litoral Centro, enquanto o litoral sul, 3ํ setor - está formado por Cabo de Santo Agostinho, Ipojuca, Rio Formoso, Sirinhaém, Tamandaré, Barreiros e São José da Coroa Grande. 


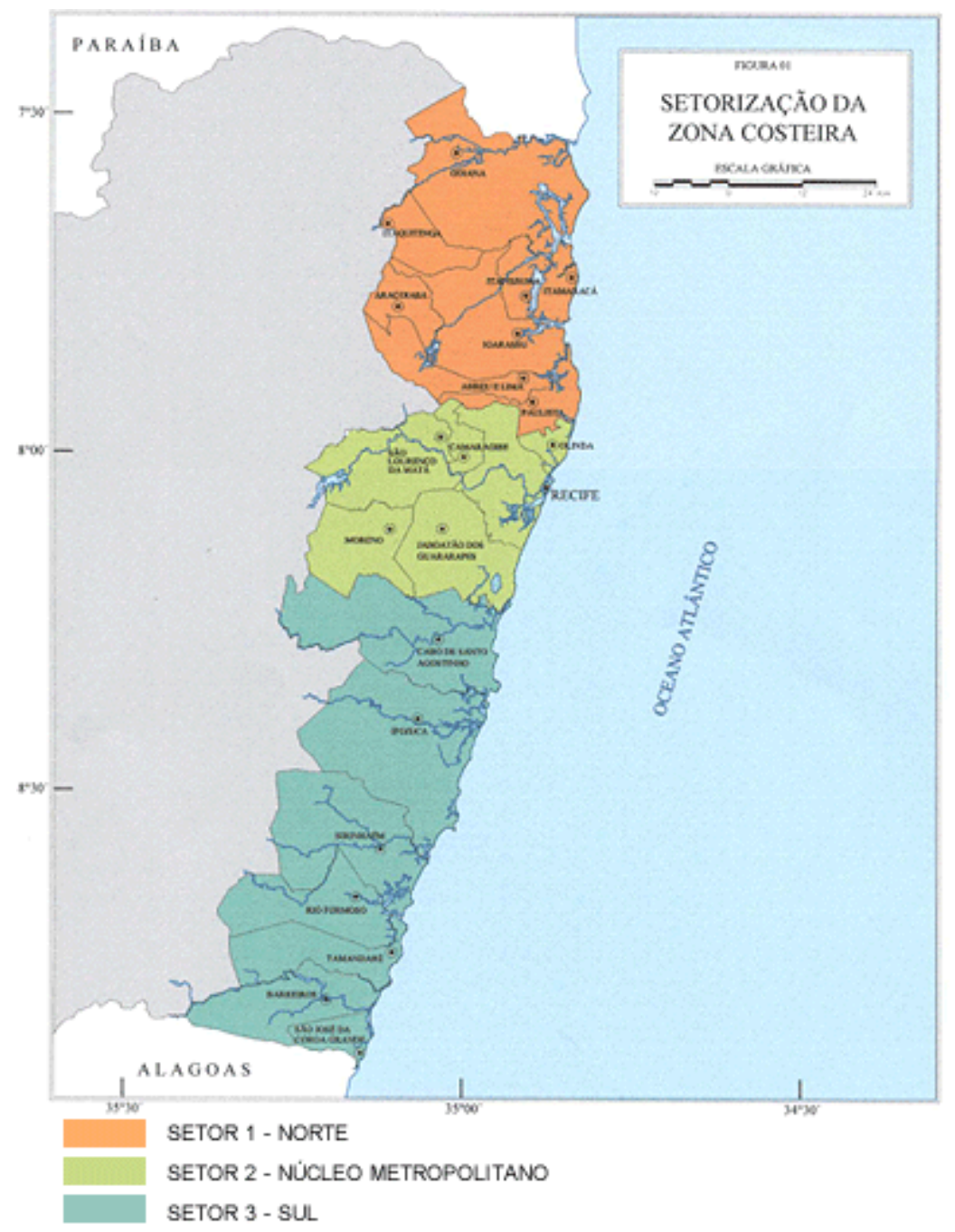

Mapa 2 - Setorização da Zona Costeira de Pernambuco (Fonte: www.cprh.pe.gov.br)

A região costeira pernambucana apresenta uma multiplicidade de ecossistemas extremamente produtivos que incluem segmentos de planícies recobertas por coqueirais, remanescentes da Mata Atlântica, estuários com extensos manguezais, recifes de arenitos e de corais, coroas, ilhas e restingas.

O litoral de Pernambuco possui 12 estuários de pequeno e médio porte e aproximadamente 60 praias que são, em sua maior parte, protegidas por cordões de arenito (breadrocks) paralelos à costa (DOMINGUEZ ET. AL., 1990). Esses cordões compõem um conjunto paisagístico único, onde se desenvolveram comunidades recifais de grande importância para a pesca, para a proteção da costa e para o turismo do Estado. 
A atividade turística se apresenta como uma das maiores responsáveis pelo processo de ocupação recente da zona costeira de Pernambuco, sendo considerado, em conjunto com outros fatores, a exemplo da construção de casas de veraneio, o principal determinante da intensificação da urbanização do litoral. Ao requerer a implantação de infra-estrutura de apoio como hotéis, pousadas, restaurantes, bares e outros equipamentos destinados a atender a demanda cada vez maior, dos fluxos internos e externos de turistas, tem a referida atividade se constituído no mais importante fator de urbanização da zona costeira ${ }^{11}$.

Essa recente ocupação do litoral também se deu, principalmente, em forma de segundas residências, muito comum no nordeste brasileiro.

\subsection{A INSTALAÇÃO DE SEGUNDAS RESIDÊNCIAS}

A residência secundária ou segunda residência é um tipo de hospedagem vinculada ao turismo de fins de semana e de temporada de férias. Embora ainda pouco estudado, esse "fenômeno" tem implicações de grandes proporções nas localidades onde existe.

Nas áreas selecionadas para as pessoas desfrutarem o período de férias ou grandes feriados, são estabelecidos os bairros de segunda residência, caracterizados pela adoção de um padrão urbano de “(...) caráter extensivo, definindo manchas urbanas contínuas, que se estendem linearmente pela linha costeira sempre estruturados por uma linha de acesso paralela ao mar" (MACEDO; PELLEGRINO, 1999 apud LIMA, 2006, p.75). Esta forma de ocupação apresenta-se de maneira uniforme em toda zona costeira.

No Brasil, o aparecimento da segunda residência dá-se na década de 1950 sob a égide do 'nacional-desenvolvimentismo' que foi responsável pela implantação da indústria automobilística, pela

\footnotetext{
${ }^{11}$ www.cprh.pe.gov.br, acessado em 13/02/2009 às 9hs30min.
} 
ascensão do rodoviarismo como matriz principal dos transportes e pela emergência de novos estratos sociais médios e urbanos que, aos poucos, começariam a incorporar entre os seus valores sócioculturais a ideologia do turismo e do lazer... O veraneio ou 0 descanso dos fins de semana se transformaram em valor social cuja satisfação levaria o turismo, de um modo muitas vezes predatório e desordenado, a regiões acessíveis a grandes centros urbanos do Centro-Sul, e com atributos ambientais valorizados (zonas costeiras e/ou serranas). (BECKER, 1995, p.10)

As casas de praias, residências turística, temporada ou veraneio utilizado para a permanência de finais de semana ou em períodos de férias e aqui identificadas como as segundas residências, "é um alojamento turístico particular, utilizados temporariamente, nos momentos de lazer, por pessoas que tem seu domicílio permanente num outro lugar" (TULIK, 2001, p.201). Sua origem é causa e efeito da metropolização brasileira que desencadeou um processo de urbanização turística ao longo do litoral do país. Constitui-se num processo de refúgio dos grupos de melhor poder aquisitivo (Foto 4) que atraídos, sobretudo pelos condicionantes naturais, buscam descanso e lazer em áreas que representem uma extensão do lugar de convivência familiar e de superação do cotidiano estressante dos grandes centros urbanos.

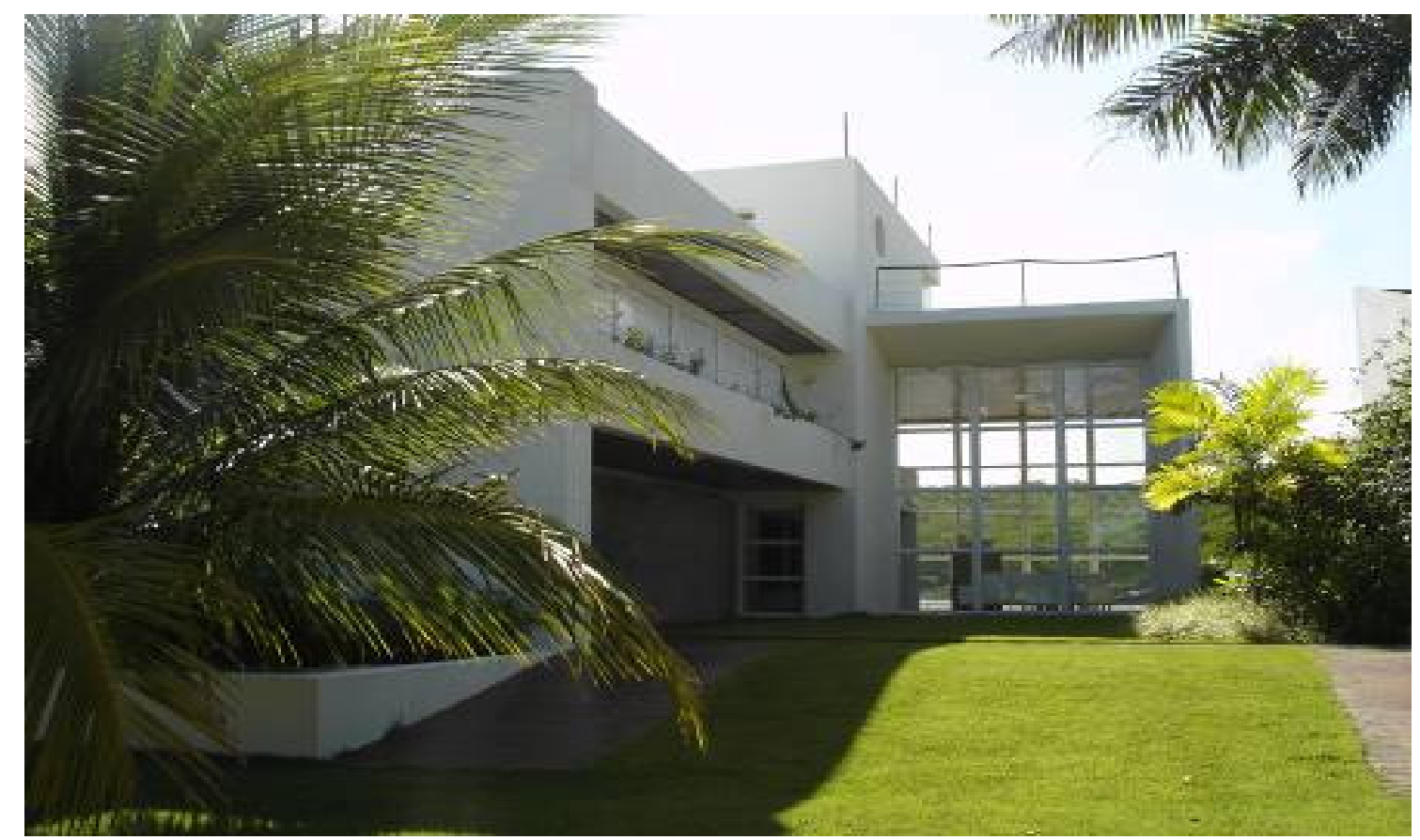

Foto 4 - Segunda residência na Praia de Toquinho - Litoral sul de Pernambuco (Fonte: Autora, 2008). 
Vários são os fatores que contribuíram para que o fim de semana se tornasse o principal período para o aproveitamento do tempo livre, como por exemplo, a redução da jornada de trabalho, do congestionamento e da poluição do meio urbano, o trânsito nas grandes cidades, entre outros, fazendo da segunda residência uma opção de fuga, descanso e saída da rotina. Além disso, a residência secundária passou também a conferir status a quem a possuísse.

A criação de espaços turísticos e de lazer, por exemplo, a partir de novas estratégias interfere na produção de novas centralidades no sentido de que produz pólos de atração que redimensionam o fluxo das pessoas num espaço mais amplo. Um movimento que é orientado pelo desenvolvimento da informação e do marketing, que "inventa" lugares onde as pessoas devem passar as férias, onde o cotidiano se encontra em aparente suspensão. O fato de que o espaço se transforma em mercadoria produz uma mobilização frenética desencadeada pelos promotores imobiliários, no plano do lugar, e pode levar à deteriorização ou mesmo à destruição de antigos lugares em razão da realização de interesses imediatos, em nome de um presente programado e lucrativo. Como conseqüência, traz a destruição de áreas imensas que passam a fazer parte do fluxo de realização do valor de troca (CARLOS, 1999).

Em meados do século $X X$, em consonância com esta tendência de instalação de segundas residências, foi construída a casa de veraneio do Governo do Estado de Pernambuco. Uma residência para férias de autoridades políticas pernambucanas, edificada durante o mandato do governador Moura Cavalcante numa área de jurisdição estadual, adquirida pelo próprio Estado no início dos anos 60. Durante mais de 30 anos, a referida residência recebeu importantes personalidades do cenário político brasileiro e foi utilizada para este fim até o último mandato do governador Miguel Arraes de Alencar entre os anos de 1994 a 1998.

Com a incorporação do turismo neste espaço nos anos 70, onde havia uma simples vila de pescadores, modificou-se com uma criação dos loteamentos possibilitando o 
surgimento das segundas residências que trouxe consigo a instalação de equipamentos de suporte a esta atividade. Iniciou-se um processo de substituição das atividades do setor primário, como a produção do côco e a pesca, através da instalação de tímidos estabelecimentos comerciais que foram adquirindo uma reconfiguração no sítio original de Porto de Galinhas e posteriormente, uma nova feição a sua artéria principal, hoje, centro de comércio e de serviços. (BARROS JUNIOR, 2002)

A acelerada expansão dos imóveis nas áreas mais afetadas da Vila de Porto, na praia de Porto de Galinhas, tem promovido a redução de imensos coqueirais e os desaparecimento das trilhas da costa. A praia, um bem público, passa a ser o maior patrimônio para o lazer, porém o acesso a esse recurso tornou-se praticamente privatizado (Foto 5). Para os técnicos do $\mathrm{CPRH}$, um dos mais sérios problemas detectados pelo Gerco/PE (Programa Nacional de Gerenciamento Costeiro Pernambuco) refere-se ao avanço litorâneo, causado principalmente pelas construções irregulares de casas e hotéis à beira-mar ou à margem dos rios. A maioria das obras irregulares provoca erosão marinha e assoreamento dos rios (acúmulo de areia no leito) (Jornal do Comércio - caderno Ciência e Meio Ambiente $-23.05 .1999)$.

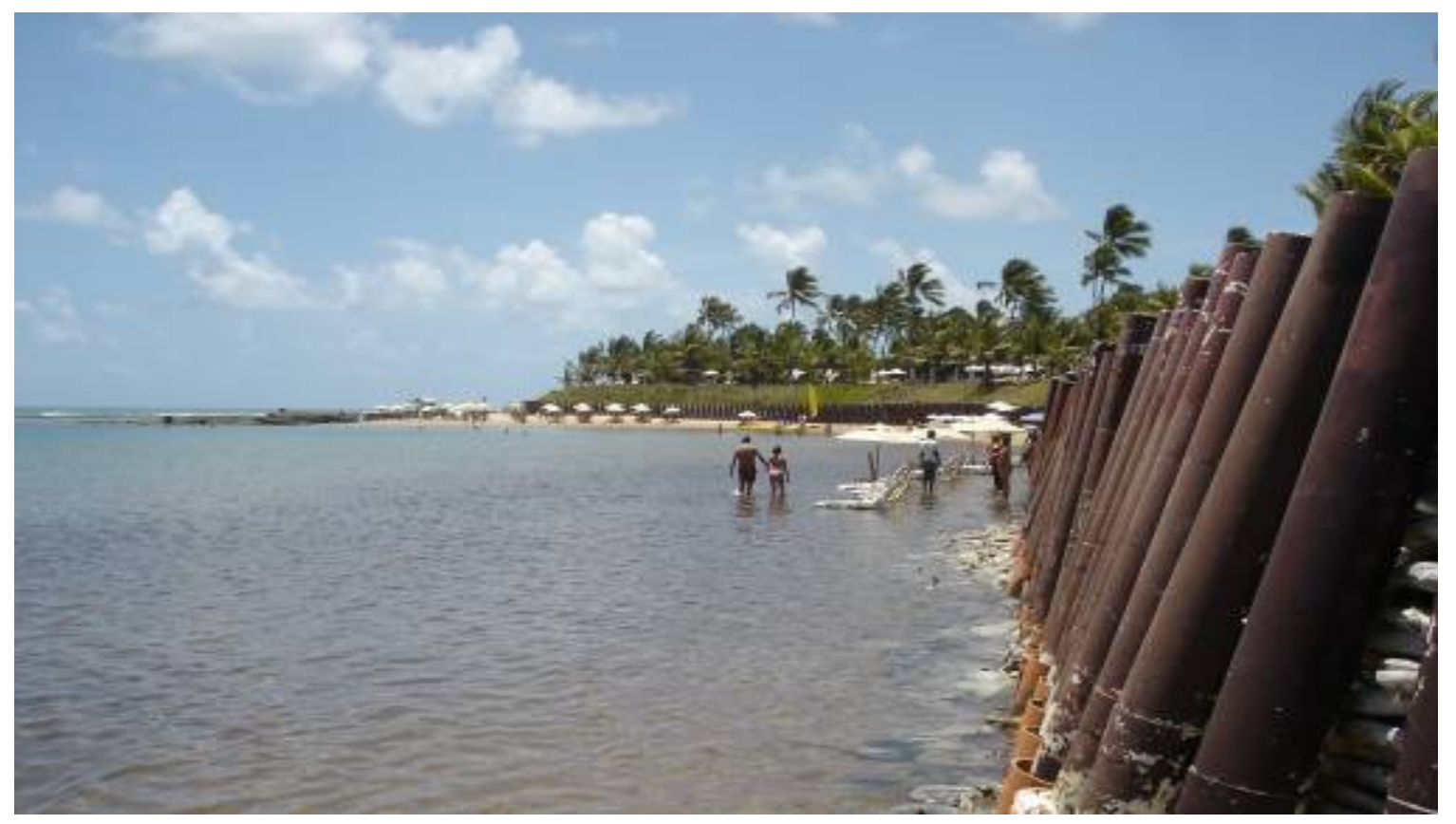

Foto 5 - Barreiras de proteção, praia de Muro Alto, litoral sul do Estado (Fonte: Autora, 2008). 
A aquisição de segunda residência pressupõe uma renda excedente para os proprietários. Os custos envolvidos na aquisição, manutenção, além dos altos impostos pagos durante o ano e custos de deslocamento até a mesma fazem com que esse tipo de alojamento não seja para toda e qualquer pessoa, mas sim apenas para uma camada privilegiada da população, conferindo ainda status para quem a possui.

Todavia, Tulik (1995, p.24) adverte que a residência secundária "é um investimento que não oferece liquidez e nem rentabilidades imediatas, pois a venda está sujeita às leis da oferta e da procura, e nem sempre estes imóveis são alugados, permanecendo vazios na maior parte do ano".

Em Pernambuco, segundo o censo do Instituto Brasileiro de Geografia e Estatística IBGE (2000), o total de segundas residências em todo o estado chega a 85.291, onde 53.885 são considerados urbanos e 31.408 rural.

Na seção a seguir, será descrito e analisado de que forma o turismo inseriu-se nos municípios litorâneos do Estado de Pernambuco e qual o papel da atividade hoje em dia nos mesmos. 
A presente seção dará ênfase ao Litoral de Pernambuco, abordando questões a respeito da sua ocupação, assim como também serão apresentados os resultados da pesquisa de campo realizada ao longo do mesmo. 


\subsection{CONHECENDO O LITORAL DE PERNAMBUCO}

Segundo estimativas do Censo de 2005 do IBGE, o Estado de Pernambuco tem 8.413.593 hab. Rico em diversos aspectos, tanto culturais como também naturais. Seu clima é predominantemente o Tropical Quente e Úmido que domina a Zona Litoral/Mata e algumas "áreas de exceção" no Agreste pernambucano. Suas chuvas são regulares e de outono/inverno com médias térmicas anuais em torno de $25^{\circ}$ e a cobertura vegetal primitiva é a de formações litorâneas, florestas, caatingas, cerrados, formação de transição floresta/caatinga. (ALECRIM, 2003)

O clima quente predominante no Estado certamente contribuiu para o hábito de freqüentar as praias desde cedo. É criada uma relação de "necessidade", onde mesmo sem ir à praia para tomar banho de mar ou para se bronzear, por exemplo, pode-se ir apenas para encontrar os amigos, ou até mesmo provar da culinária típica vendida apenas a beira-mar.

No que concerne aos atrativos turísticos naturais ${ }^{12}$, Pernambuco apresenta, como principais fatores para atração de correntes turísticas, o arquipélago de Fernando de Noronha, considerado pela UNESCO (Organização das Nações Unidas para educação, ciência e cultura) como "Patrimônio Natural da Humanidade" e um litoral com $187 \mathrm{~km}$ de extensão. Outro importante atrativo natural é o Planalto da Borborema e toda mudança de paisagem, clima e atividades turísticas que surgem em sua decorrência. Por fim, o Vale do São Francisco Pernambucano, oportunizando variadas formas de exploração do turismo para região. (ALECRIM, 2003)

\footnotetext{
12 Atrativos naturais são aqueles nos quais não houve intervenção do homem, tais como florestas, acidentes geográficos, formações rochosas. Atualmente é difícil encontrar recursos naturais em estado puro, pois a maior parte dos turistas procura, quando viaja, um nível de conforto semelhante ao que lhe oferece a ávida urbana. (BARRETO, 2001, p.40)
} 
Ainda segundo o autor, quanto aos atrativos culturais, não só em relação à Região Nordeste, mas também ao Brasil, Pernambuco detém um dos mais ricos patrimônios da categoria, através de sua história, arquitetura civil, militar e religiosa, artesanato, folclore, gastronomia, artes cênicas, música, religião, festas populares e eventos.

Sua forte vitalidade cultural é percebida também através de eventos ocorridos em diversas épocas do ano, como é o caso do carnaval, de imagem já consolidada, da semana santa, onde milhares de famílias pernambucanas deslocam-se para o interior do Estado, das festas juninas ocorridas tanto na capital Recife como também em Caruaru e em dezenas de outros municípios, das festas natalinas e de final de ano e do próprio verão, época de maior concentração de turistas vindos de todas as partes do mundo.

Atualmente, o Estado é um dos três principais do Nordeste brasileiro no que diz respeito à recepção de turistas (Tabela 2), ficando atrás apenas da Bahia e do Ceará. A principal característica da atividade no Estado é a larga exploração do turismo de massa. (SETUR/PE - Secretaria de Turismo de Pernambuco, 2008)

Tabela 2 - Fluxo Global de Turistas de Pernambuco (Fonte: EMPETUR - Empresa de Turismo de Pernambuco)

\begin{tabular}{|r|r|r|}
\hline Anos & Pernambuco & $\begin{array}{c}\% \\
\text { Evolução }\end{array}$ \\
\hline $\mathbf{1 9 9 6}$ & 1.329 .576 & \multicolumn{1}{c|}{} \\
\hline $\mathbf{1 9 9 7}$ & 1.573 .576 & $18,4 \%$ \\
\hline $\mathbf{1 9 9 8}$ & 1.903 .781 & $21,0 \%$ \\
\hline $\mathbf{1 9 9 9}$ & 2.310 .862 & $21,4 \%$ \\
\hline $\mathbf{2 0 0 0}$ & 2.654 .165 & $14,9 \%$ \\
\hline $\mathbf{2 0 0 1}$ & 3.216 .748 & $21,2 \%$ \\
\hline $\mathbf{2 0 0 2}$ & 3.277 .475 & $1,9 \%$ \\
\hline $\mathbf{2 0 0 3}$ & 3.312 .780 & $1,1 \%$ \\
\hline $\mathbf{2 0 0 4}$ & 3.351 .550 & $1,2 \%$ \\
\hline $\mathbf{2 0 0 5}$ & 3.498 .219 & $4,4 \%$ \\
\hline $\mathbf{2 0 0 6}$ & 3.530 .046 & $0,9 \%$ \\
\hline
\end{tabular}


A redução da demanda que teve início de 2001 com ápice em 2002 possivelmente foi causada pela desvalorização do peso argentino, visto que a Argentina era e ainda é um grande emissor de turistas para o Brasil, além do atentado de 11 de setembro ocorrido nos EUA; outro fator a ser levado em consideração para tal estagnação foi a forte concorrência com outros Estados nordestinos como é o caso do Rio Grande do Norte e Ceará que começaram a investir fortemente também no turismo.

Ainda segundo os dados do Planejamento Estratégico, o Estado de Pernambuco atrai turistas de nível sócio-econômico médio, cuja permanência está diretamente atrelada aos pacotes adquiridos junto a operadoras de viagens, dificilmente superando os cinco a sete dias e os destinos turísticos mais visitados no Estado são: Porto de Galinhas, Recife/Olinda e Fernando de Noronha. É nítido que o turismo no Estado está concentrado numa determinada área sendo esta, próxima da capital Recife, e que abrange sua faixa litorânea, principalmente o Litoral Sul.

Assim como outros Estados do Nordeste, Pernambuco sofre com a sazonalidade da demanda, concentrada principalmente nos meses de férias escolares, durante 0 verão brasileiro - dezembro a fevereiro.

Stanfield (1972) apud Lima (2006) identifica dois tipos de destinos costeiros quanto à origem e estrutura: aqueles em que já existe um assentamento humano prévio e ocorre uma interação ou obscurecimento das funções econômicas anteriores a ela e aqueles que são fundados como destinos turísticos. Em Pernambuco, tem-se basicamente a existência do primeiro tipo.

Muitas vezes o turismo ao chegar numa localidade provoca o desaparecimento ou substituição de antigas atividades econômicas, como é o caso da Praia de Porto de Galinhas, onde pescadores trocaram sua profissão para se tornarem jangadeiros a fim de realizarem passeios com os turistas. 
No tocante ao assunto Cruz (2000) apud Lima (2006, p.76) nos fala que:

Observando a realidade das destinações turísticas do litoral do Nordeste brasileiro, identifica duas situações, uma de produção do espaço pelo turismo e outra para o turismo. A primeira situação implica na criação de uma série de objetos (hotéis, restaurantes, agências de viagens e locação de veículos, vias de acesso, territórios turísticos, etc.), sendo a urbanização do espaço também uma urbanização turística. $\mathrm{Na}$ segunda, planeja-se a urbanização do espaço prevendo-se o uso turístico.

Luchiari (1998) apud Cruz (2002) ao falar da urbanização turística com expressão do fenômeno turístico ressalta sua capacidade transformadora do espaço, que recria a identidade do lugar e produz um espaço social híbrido, "onde o velho e o novo fundem-se dando lugar a uma nova organização socioespacial". Este movimento entre o velho e o novo, acelerado pela urbanização turística, gera novas paisagens, consome outras, traz à cena novos sujeitos sociais, elimina ou marginaliza outros e redesenha as formas de apropriação do espaço urbano, substituindo antigos usos e legendo novas paisagens a serem valorizados pelo lazer.

\subsection{A SETORIZAÇÃO DA ZONA COSTEIRA PERNAMBUCANA}

A Zona Costeira de Pernambuco, como já dito anteriormente foi divida pelo em setores distintos: o Setor Norte, o Setor Metropolitano e o Setor Sul. Cada um desses setores merece especial destaque e será abordado em suas especificidades.

\subsubsection{SETOR NORTE: APOGEU E DECADÊNCIA}

O Litoral Norte de Pernambuco abrange 8 municípios, sendo estes: Abreu e Lima, Araçoiaba, Goiana, Igarassu, Ilha de Itamaracá, Itapissuma, Itaquitinga e Paulista. 
Tabela 3 - Dados físicos, sociais e econômicos do Litoral Norte (Fonte: CONDEPE/FIDEM, 2008)

\begin{tabular}{|c|c|c|c|c|c|c|c|c|}
\hline Característica & $\begin{array}{l}\text { Abreu } \\
\text { e Lima }\end{array}$ & $\begin{array}{c}\text { Araçoia } \\
\text { ba }\end{array}$ & Goiana & Igarassu & Itamaracá & Itapissuma & $\begin{array}{l}\text { Itaquitin- } \\
\text { ga }\end{array}$ & Paulista \\
\hline \multicolumn{9}{|c|}{ Aspectos Físicos } \\
\hline $\begin{array}{l}\text { Área do Município } \\
\left(\mathrm{km}^{2}\right)\end{array}$ & 125,99 & 96,38 & 501,17 & 305,57 & 65,41 & 74,25 & 103,44 & 93,52 \\
\hline $\begin{array}{l}\text { Distância à Capital } \\
(\mathrm{km})\end{array}$ & 21,4 & 38,0 & 63,0 & 32,3 & 48,0 & 39,0 & 84,0 & 19,0 \\
\hline População* & 92.217 & 16.520 & 71.796 & 93.748 & 17.573 & 22.852 & 14.985 & 262.237 \\
\hline $\begin{array}{l}\text { Taxa de } \\
\text { Urbanização* }\end{array}$ & 91,61 & 78,61 & 76,93 & 91,25 & 79,11 & 76,40 & 75,10 & $\ldots$ \\
\hline $\begin{array}{l}\text { Densidade } \\
\text { Demográfica* (hab / } \\
\text { km }^{2} \text { ) }\end{array}$ & 731,93 & 171,40 & 143,26 & 306,80 & 14,87 & 307,78 & 144,86 & $3.285,83$ \\
\hline $\begin{array}{l}\text { Taxa anual de } \\
\text { crescimento } \\
\text { demográfico* }(\%)\end{array}$ & 0,53 & 1,35 & 0,13 & 1,98 & 1,55 & 1,93 & 0,04 & 2,41 \\
\hline $\begin{array}{l}\text { Taxa de domicílios } \\
\text { urbanos (\%) }\end{array}$ & 92,74 & 79,03 & 78,14 & 91,93 & 91,94 & 79,03 & 74,92 & 100,00 \\
\hline \multicolumn{9}{|c|}{ Aspectos Sociais e Econômicos } \\
\hline $\begin{array}{l}\text { Taxa de } \\
\text { analfabetismo** } \\
\text { (acima de } 25 \text { anos) }\end{array}$ & 16,78 & 46,63 & 29,69 & 23,65 & 20,81 & 31,82 & 41,97 & 9,66 \\
\hline $\begin{array}{l}\text { Mortalidade Infantil } \\
\text { por } 1.000 \\
\text { nascidos }^{\star \star \star}(2005)\end{array}$ & 16,90 & 30,50 & 19,80 & 13,30 & 9,00 & 7,40 & 25,80 & 12,60 \\
\hline $\begin{array}{l}\text { Leitos hospitalares } \\
\text { por } 1.000 \\
\text { habitantes }^{\star \star \star}\end{array}$ & 1,20 & 0,20 & 1,70 & 1,70 & 20,70 & 0,40 & 0,40 & 1,60 \\
\hline $\begin{array}{l}\text { PIB Municipal (R\$ } \\
1.000,00)^{\star \star \star \star}\end{array}$ & $\begin{array}{c}548.08 \\
4 \\
\end{array}$ & 48.822 & 446.043 & 664.465 & 75.925 & 405.552 & 51.266 & 1.221 .365 \\
\hline $\begin{array}{l}\text { Participação no PIB } \\
\text { de Pernambuco**** } \\
(\%)\end{array}$ & 0,99 & 0,09 & 0,80 & 1,20 & 0,14 & 0,73 & 0,09 & 2,20 \\
\hline 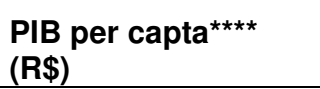 & $\begin{array}{c}5.598 \\
00\end{array}$ & $2.728,00$ & $5.840,00$ & $7.187,00$ & $3.996,00$ & $17.743,00$ & $3.280,00$ & $4.075,00$ \\
\hline
\end{tabular}

${ }^{*}$ Fonte: IBGE (inclusive população estimada nos domicílios fechados) 1991-2000

${ }^{* *}$ Fonte: Pnud//pea/FJP, Atlas do Desenvolvimento Humano no Brasil.

${ }^{* * *}$ Fonte: Datasus - Considerando apenas os óbitos e nascimentos coletados pelo SIM/SINASC

****Fonte: IBGE / Agência CONDEPE/FIDEM - Ano de Referência: 2002 (dados sujeitos a revisão)

Segundo o IBGE (2000), o litoral norte totaliza $1377,3 \mathrm{~km}^{2}$ ou $1,4 \%$ da superfície do Estado, sendo esta bem mais populosa que o litoral sul. 
Compreendendo a porção norte da faixa costeira do Estado, este segmento litorâneo localiza-se na área de domínio do clima tropical úmido. Esse tipo climático tem como traços característicos a temperatura do mês menos quente superior a $18^{\circ} \mathrm{C}$ e chuvas de outono-inverno motivadas pelos ciclones da Frente Polar Atlântica (FPA), que nessa época do ano atinge com maior vigor a costa oriental nordestina. As temperaturas médias anuais da área oscilam em torno de $24^{\circ} \mathrm{C}$, nos meses de julho e agosto (considerados os menos quentes do ano) é de $270 \mathrm{C}$, em fevereiro (o mês mais quente), apresentando amplitude térmica anual relativamente fraca (cerca de $30 \mathrm{C})$. (CPRH, 2003)

Assim como no Litoral Sul, o Litoral Norte tem no cultivo da cana-de-açúcar e na agroindústria sucroalcooleira a base de sua economia e teve a constituição de seu espaço associada à pesca e à exploração do côco, na orla marítima.

Introduzida na área no século XVI, a cultura da cana-de-açúcar tornar-se-á a forma de uso e ocupação do solo predominante na porção setentrional úmida do Estado, dividindo esse papel com o côco, à medida que se avizinha da orla marítima, onde o coqueiro era até bem pouco tempo o elemento dominante da paisagem. Em meio a tais formas de exploração do solo e a elas associados, surgem os núcleos populacionais que em ritmos diversos, evoluem para transformarem-se nas cidades, vilas e povoados que compõem o quadro urbano do segmento territorial em apreço. (CPRH, 2003)

A atividade da pesca ainda ocupa um papel de destaque na sobrevivência das comunidades do Litoral Norte de Pernambuco, predominantemente realizada de forma artesanal (Foto 6), contribuindo, portanto, na alimentação das famílias dependentes da pesca onde o pescado é vendido em sua grande parte em mercados públicos, bares e restaurantes, além dos ambulantes. 


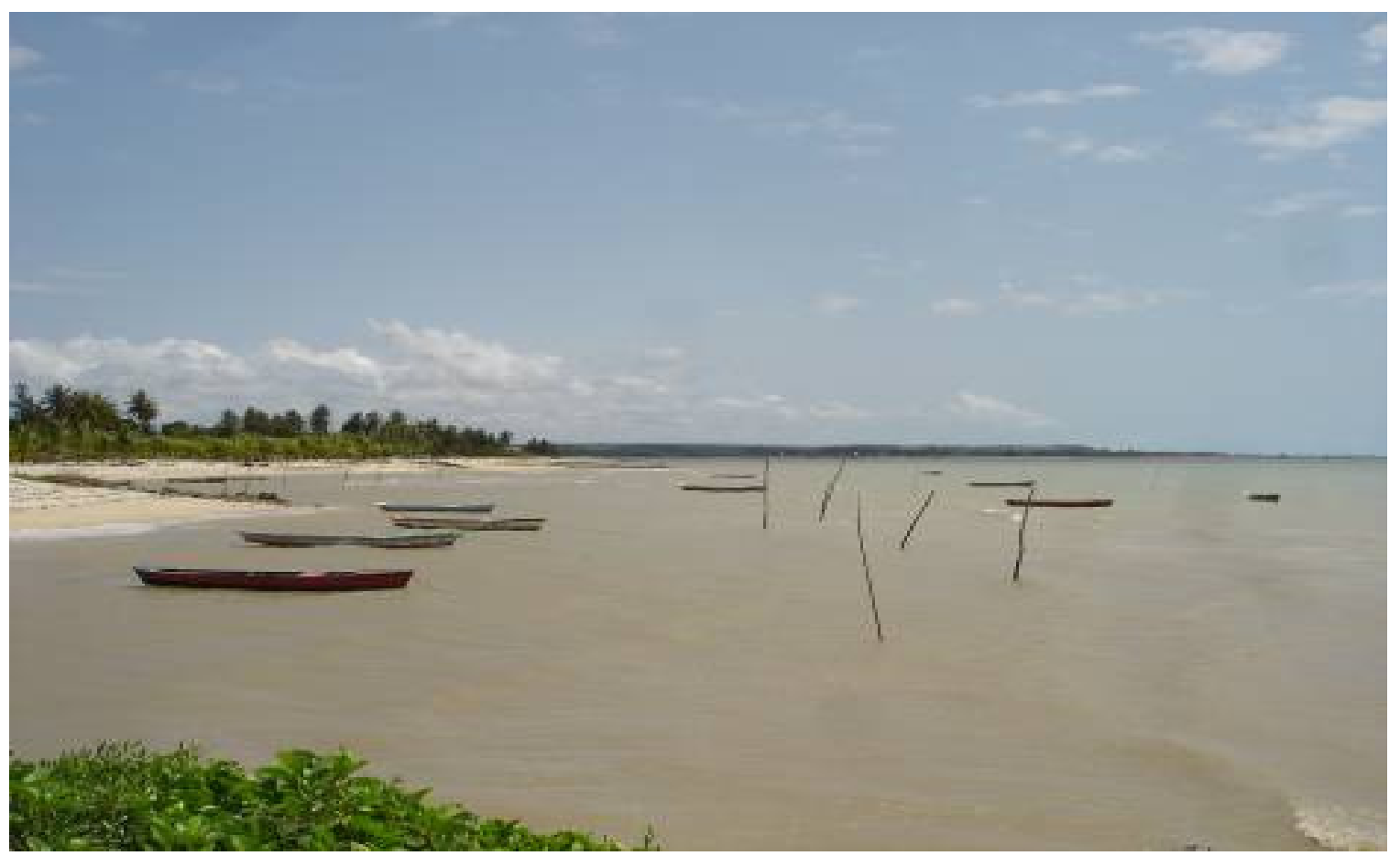

Foto 6 - Barcos usados na pesca artesanal no litoral norte (Fonte: Autora, 2008).

Construídos com base em estatísticas oficiais (produzidas pelo IBGE e pelo Governo do Estado), os indicadores sociais para o Litoral Norte revelam a predominância na área de renda familiar baixa, elevado percentual de analfabetos, sobretudo, na zona rural, moradias de baixo padrão construtivo e condições sanitárias precárias. ( $\mathrm{CPRH}$, 2003)

Ainda segundo o $\mathrm{CPRH}$, este segmento industrial é na maior parte constituído por unidades de médio porte, e em menor escala por unidades de grande e pequeno porte. Muitas dessas indústrias têm a matriz no Centro Sul do país ou pertencem a grupos alí sediados. Não obstante, tais características, as unidades integrantes têm apresentado reduzido poder de permanência na área, sendo significativo o número de empresas, que nos últimos dez anos fecharam ou entraram em crise, transferindo para o setor informal da economia um contingente crescente da força de trabalho urbana. 
As indústrias referenciadas são em sua grande parte pertencentes ao gênero têxtil e vestuário, químicas e produtos de matérias plásticas, metalúrgica, mecânica e material elétrico, extração de minerais e de comunicação.

Uma característica relevante da concentração urbana litorânea é a existência, ali de dois setores distintos quanto ao período de ocupação das moradias e à utilização dos serviços que atendem à população: os setores de ocupação permanente e os de veraneio. No primeiro caso, incluem-se os setores urbanos ocupados pela população nativa (residente nos núcleos antigos) ou pelo contingente de renda média e média-alta que, aos poucos, foi transferindo sua residência de Recife e Olinda para a orla litorânea dos municípios próximos dessas cidades, onde já eram veranistas. No segundo caso, situam-se as áreas cuja ocupação das moradias ocorre apenas nos meses de verão ou de alta estação (dezembro a fevereiro), bem como em feriados prolongados (Foto 7). (CPRH, 2003)

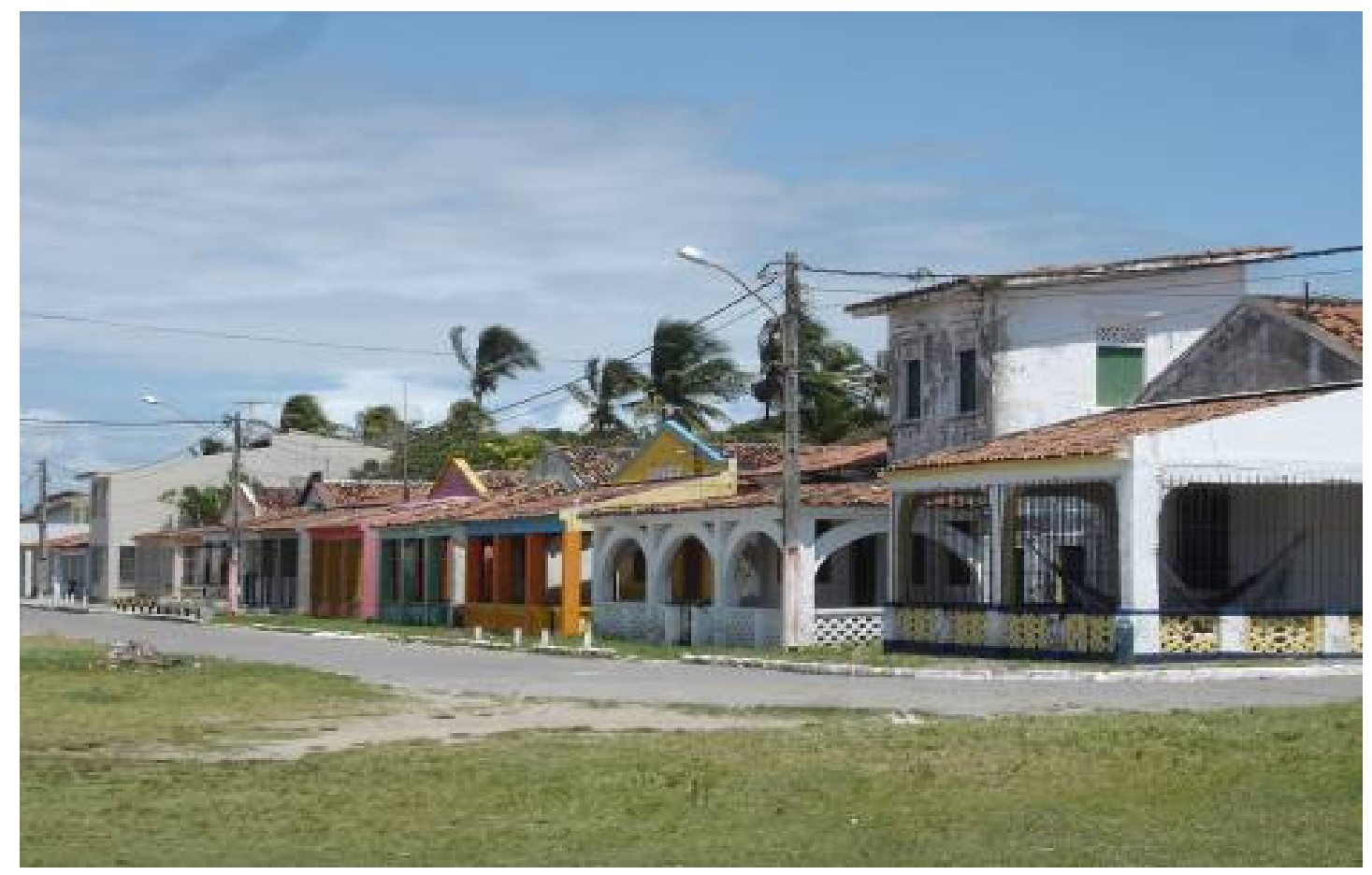

Foto 7 - Segundas residências na praia de Carne de Vaca, Litoral norte. (Fonte: Autora, 2008)

As praias do Litoral Norte tiveram o apogeu referente à atividade turística nas décadas de setenta, oitenta até o início dos anos noventa, principalmente as praias da Ilha de Itamaracá e Maria Farinha. Por fatores diversos, como por exemplo, a 
instalação de três presídios em Itamaracá ${ }^{13}$, o "modismo" e a divulgação ampla da Praia de Porto de Galinhas, houve uma "migração" dos seus freqüentadores e de turistas para o litoral sul do Estado, mais precisamente para a já citada a praia de Porto de Galinhas, Muro Alto e Maracaípe, deixando um rastro de abandono e decadência. (Foto 8)

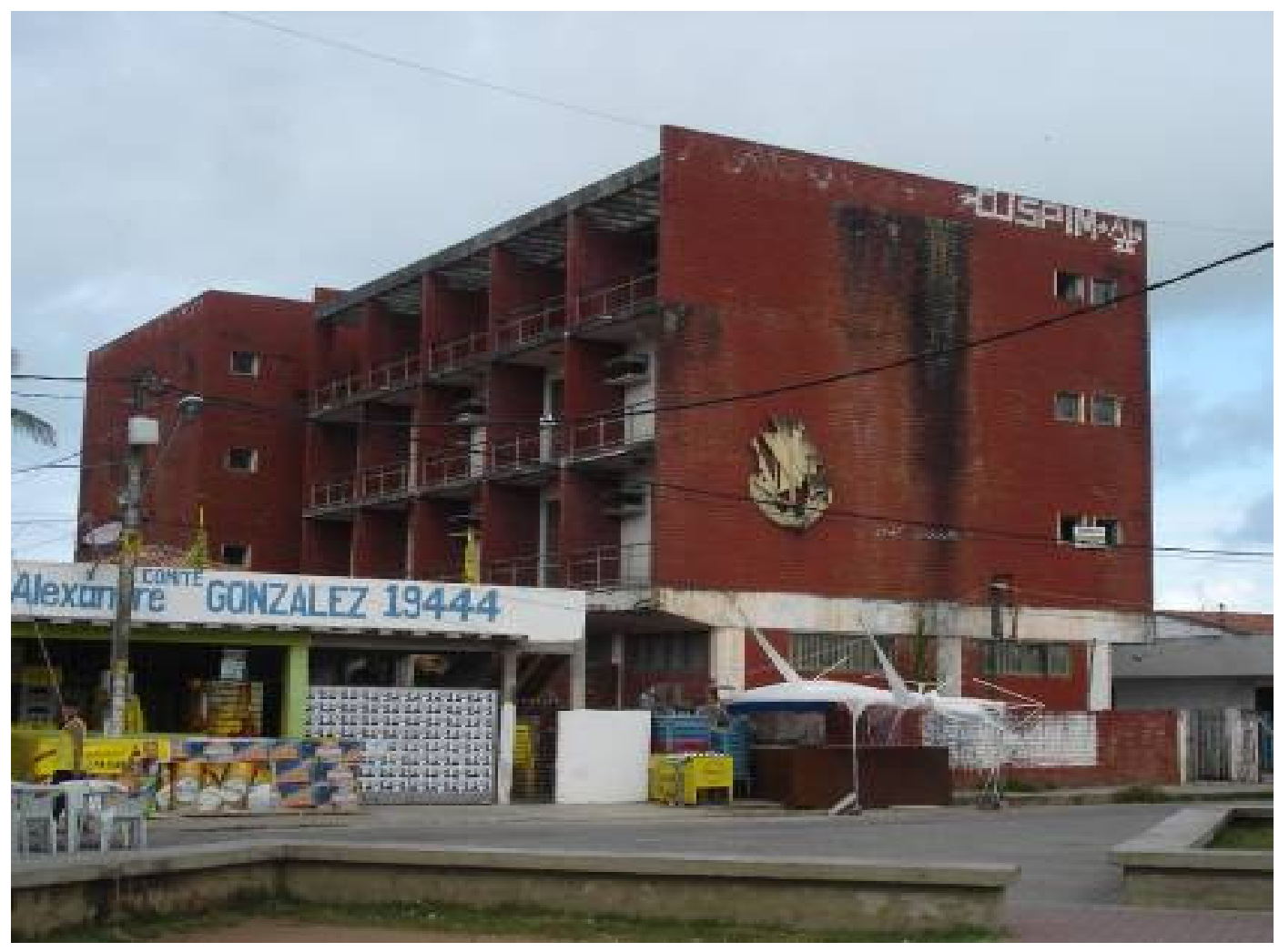

Foto 8 - Antigo hotel na praia de Itamaracá, litoral norte. (Fonte: Autora, 2008)

Nas últimas três décadas, a venda de terrenos para segundas residências foi o principal produto turístico de Itamaracá. A especulação imobiliária ditou o parcelamento do solo para a abertura dos loteamentos, resultando numa alta densidade de ocupação do espaço litorâneo. (ASSIS, 2003, p.121)

Como exemplo dessa especulação, os terrenos para loteamentos na medida de $13 \mathrm{~m}$ x 40m custavam em média $R \$ 10.000,00$ no início da década de 90 e hoje, essa mesma medida custa 3 vezes mais, ficando em torno de $\mathrm{R} \$ 30.000,00$.

${ }^{13}$ Penitenciário Barreto Campelo (segurança máxima), Penitenciária Agrícola de Itamaracá (regime semi-aberto) e Manicômio Judiciário. 


\subsubsection{SETOR METROPOLITANO}

São consideradas as praias do setor metropolitano, as pertencentes ao município de Olinda (Nossa Senhora do Ó, Rio Doce, Casa Caiada, Bairro Novo e Praia Del Chifre), Recife (Brasília Teimosa e Boa Viagem) e Jaboatão dos Guararapes (Piedade, Candeias e Barra de Jangada).

Tabela 4 - Dados físicos, sociais e econômicos do Litoral Metropolitano

\begin{tabular}{|c|c|c|c|}
\hline Característica & Recife & Olinda & Jaboatão \\
\hline \multicolumn{4}{|c|}{ Aspectos Físicos } \\
\hline Área do Município $\left(\mathrm{km}^{2}\right)$ & 217,49 & 43,55 & 256,07 \\
\hline Distância à Capital (km) & 0,0 & 6,0 & 19,4 \\
\hline População* & 1.422 .905 & 367.902 & 581.556 \\
\hline Taxa de Urbanização* & $\ldots$ & $\ldots$ & $\ldots$ \\
\hline Densidade Demográfica* (hab / km²) & $7.051,14$ & $8.988,54$ & $2.598,43$ \\
\hline Taxa anual de crescimento demográfico* (\%) & 1,13 & 0,93 & 2,04 \\
\hline Taxa de domicílios urbanos (\%) & $\ldots$ & $\ldots$ & $\ldots$ \\
\hline \multicolumn{4}{|c|}{ Aspectos Sociais e Econômicos } \\
\hline Taxa de analfabetismo ${ }^{\star \star}$ (acima de 25 anos) & 11,70 & $367.902,00$ & 14,74 \\
\hline Mortalidade Infantil por 1.000 nascidos $^{\star \star \star}(2005)$ & 16,60 & 18,90 & 17,10 \\
\hline Leitos hospitalares por 1.000 habitantes ${ }^{\star * *}$ & 5,90 & 0.9 & 0.9 \\
\hline PIB Municipal $(\mathbf{R} \$ 1.000,00)^{\star \star \star \star}$ & 18.318 .451 & 2.005 .665 & 4.736 .433 \\
\hline 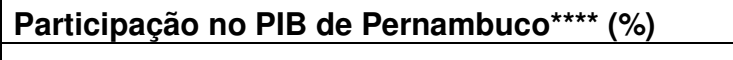 & 33,00 & 3,61 & 8,53 \\
\hline PIB per capta ${ }^{\star \star * \star}(R \$)$ & $12.091,00$ & $5.176,00$ & $7.272,00$ \\
\hline \multicolumn{4}{|c|}{$\begin{array}{l}\text { nte: CONDEPE/FIDEM, 2008) } \\
\text { nte: IBGE (inclusive população estimada nos domicílios fechados) 1991-2000 }\end{array}$} \\
\hline
\end{tabular}

A Praia de Boa Viagem é a mais urbana e conhecida da Cidade do Recife e encontra-se entre as praias do Pina e de Piedade. A maioria dos hotéis de grande porte da capital pernambucana encontra-se nesta porção da cidade. Grande parte dela é protegida por arrecifes naturais, que deram origem ao nome da cidade. Além 
de suas belezas naturais, a praia de Boa Viagem também ficou conhecida pelos ataques de tubarões (Foto 9) sofridos por banhistas e surfistas.

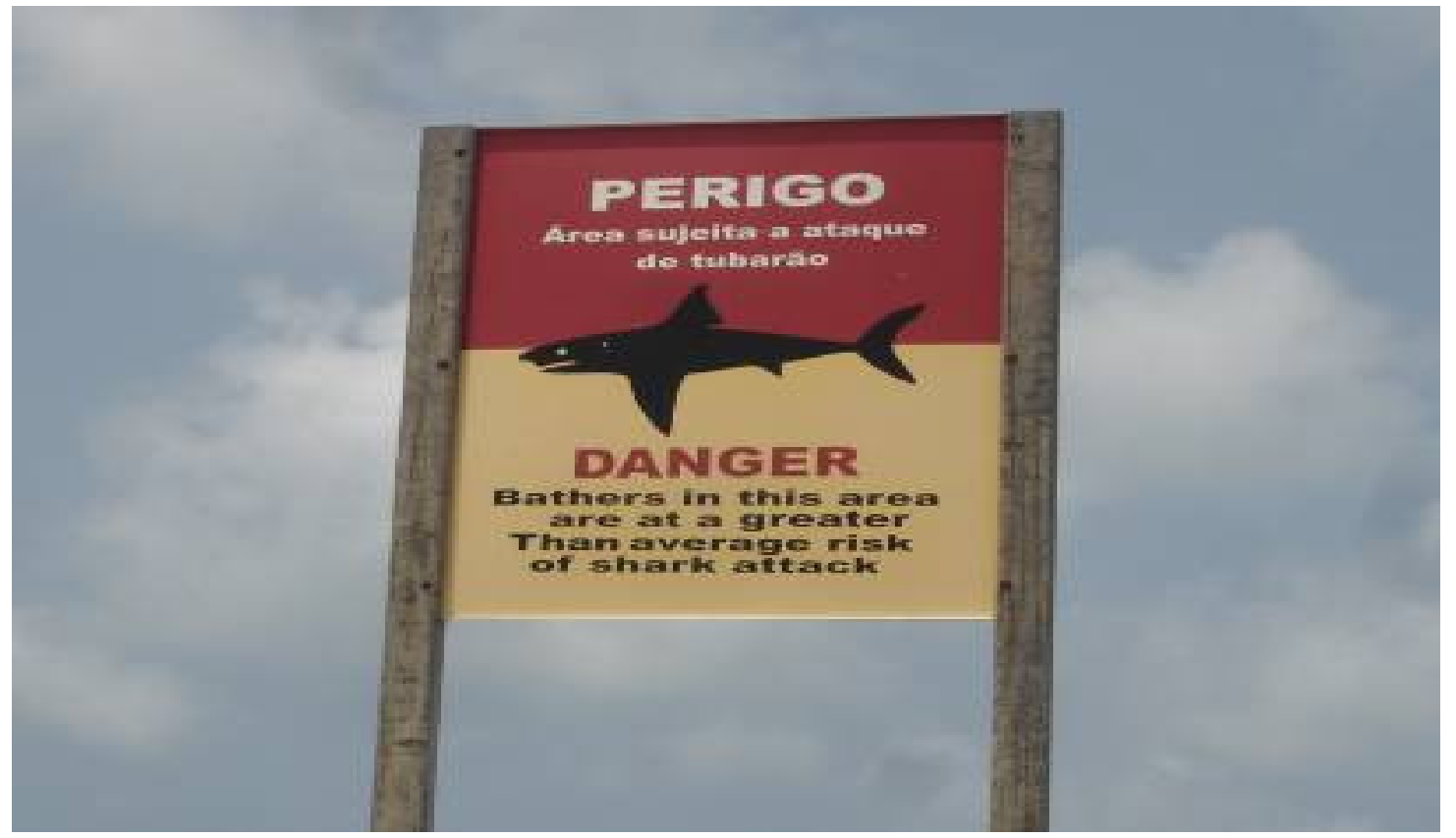

Foto 9 - Placa de advertência referente aos ataques de tubarão na praia de Boa Viagem, litoral metropolitano (Fonte: Autora, 2008).

$\mathrm{Na}$ década de 70, a praia da Boa Viagem foi palco da exploração turística que acelerou seu processo de urbanização. Sem planejamento adequado, a orla da Boa Viagem passou a ser explorada não só pela atividade turística, mas também pela atividade imobiliária (Foto 10), resultando na perda das características ambientais. A especulação imobiliária na área acelerou a verticalização e aumentou o custo de vida da população local, sendo o bairro da Boa Viagem um dos bairros com maior custo de vida da cidade. Devido ao crescimento desordenado, parte da praia sofreu mudança paisagista devido aos processos de erosão costeira (SILVA ET AL, 2006, p.92). 


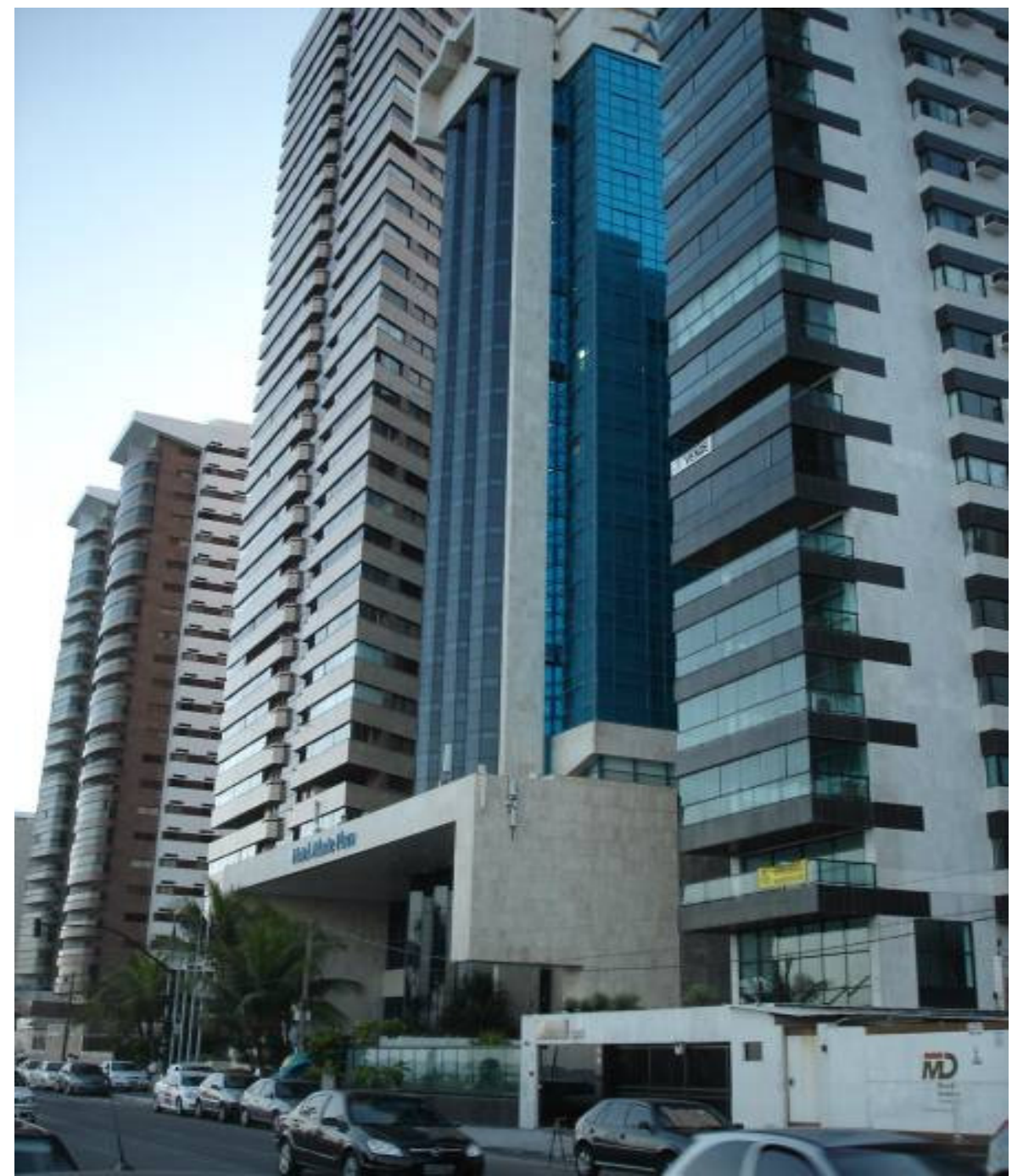

Foto 10 - Prédios na praia de Boa Viagem, litoral metropolitano (Fonte: Autora, 2008).

Boa Viagem possui vários problemas graves, dentre eles, dois canais de esgoto abertos que prejudicam a paisagem do bairro trazendo mau cheiro e proporcionando a proliferação de mosquitos e de doenças, além de desaguar diretamente na praia.

No bairro em questão, também existe um amontoado de edifícios que dificultam a circulação de ventos, acarretando em uma grande quantidade de pessoas morando no local ou que por ali circulam e por isso há um grande número de engarrafamentos e acidentes. Da mesma forma ocorreu em algumas cidades litorâneas, como é o caso de Balneário Camburiú, em Santa Catarina, Fortaleza, capital do Ceará e no Guarujá, em São Paulo, por exemplo. 
O contraste social é perceptível, ao lado do Shopping Center Recife e de vários outros prédios luxuosos, existe uma enorme favela, aumentando também o índice de criminalidade no bairro, motivo este que "empurra" os moradores para atividades de lazer em locais fechados como é o caso de playgrounds, boates, videogame, internet, jogos de computadores, entre outros.

A exploração do trabalho infantil também é visível, sejam nos sinais, esquinas ou até mesmo pedindo esmolas, além do alto índice de prostituição: inclusive envolvendo menores de idade. A Secretaria de Turismo da cidade do Recife lançou em 2008 o Código de Combate à exploração sexual de crianças e adolescentes no turismo, sendo este um manual de boas práticas distribuídos para todo o trade turístico para que o mesmo colabore nesse combate.

No litoral sul do Estado também há graves problemas sociais, porém, o modismo de suas praias e as altas taxas de visitações, acaba mascarando um pouco desses problemas.

\subsubsection{SETOR SUL: BADALAÇÃO E MODISMO NO LITORAL PERNAMBUCANO}

O litoral sul de Pernambuco abrange sete municípios: Cabo de Santo Agostinho, Ipojuca, Sirinhaém, Rio Formoso, Tamandaré, Barreiros, São José da Coroa Grande.

Tabela 5 - Dados físicos, sociais e econômicos do Litoral Sul

\begin{tabular}{|c|c|c|c|c|c|c|c|}
\hline Característica & Cabo & Ipojuca & Sirinhaém & $\begin{array}{c}\text { Rio } \\
\text { Formoso } \\
\end{array}$ & Tamandaré & Barreiros & S. José \\
\hline \multicolumn{8}{|c|}{ Aspectos Físicos } \\
\hline Área do Município $\left(\mathrm{km}^{2}\right)$ & 447,88 & 527,32 & 378,79 & 239,81 & 190,02 & 233,37 & 69,20 \\
\hline Distância à Capital (km) & 33,6 & 50,2 & 79,1 & 91,0 & 111,0 & 108,8 & 121,3 \\
\hline População* & 163.139 & 70.070 & 36.414 & 21.024 & 18.137 & 41.748 & 17.090 \\
\hline Taxa de Urbanização* & 88,31 & 69,06 & 53,00 & 61,42 & 69,20 & 84,10 & 71,85 \\
\hline $\begin{array}{l}\text { Densidade Demográfica* (hab / } \\
\mathbf{k m}^{2} \text { ) }\end{array}$ & 364,25 & 105,27 & 96,13 & 87,67 & 95,45 & 178,89 & 246,98 \\
\hline
\end{tabular}




\begin{tabular}{|c|c|c|c|c|c|c|c|}
\hline $\begin{array}{l}\text { Taxa anual de crescimento } \\
\text { demográfico* }(\%)\end{array}$ & 0,97 & 2,54 & 1,47 & 0,19 & 0,73 & 0,97 & 3,07 \\
\hline Taxa de domicílios urbanos (\%) & 89,37 & 73,38 & 54,90 & 65,21 & 72,57 & 85,77 & 73,04 \\
\hline \multicolumn{8}{|c|}{ Aspectos Sociais e Econômicos } \\
\hline $\begin{array}{l}\text { Taxa de analfabetismo** (acima } \\
\text { de } 25 \text { anos) }\end{array}$ & 24,31 & 37,03 & 40,28 & 40,56 & 45,77 & 37,30 & 58,99 \\
\hline $\begin{array}{l}\text { Mortalidade Infantil por } 1.000 \\
\text { nascidos }\end{array}$ & 15,90 & 14,90 & 25,00 & 34,10 & 19,20 & 21,10 & 12,60 \\
\hline $\begin{array}{l}\text { Leitos hospitalares por } 1.000 \\
\text { habitantes }{ }^{\star \star \star}\end{array}$ & 1,70 & 0,40 & 2,70 & 3,10 & 0,90 & 5,10 & 1,30 \\
\hline PIB Municipal $(\mathrm{R} \$ 1.000,00)^{\star \star \star \star}$ & 2.838 .063 & 4.307 .573 & 163.705 & 148.723 & 81.288 & 123.191 & 48.945 \\
\hline $\begin{array}{l}\text { Participação no PIB de } \\
\text { Pernambuco }^{\star \star \star \star}(\%)\end{array}$ & 5,11 & 7,76 & 0,29 & 0,27 & 0,15 & 0,22 & $0, .09$ \\
\hline PIB per capta**** $(\mathbf{R} \$)$ & $16.486,00$ & $61.959,00$ & $4.978,00$ & $6.745,00$ & $4.254,00$ & $3.235,00$ & $3.103,00$ \\
\hline
\end{tabular}

Fonte: (CONDEPE/FIDEM, 2008)

*Fonte: IBGE (inclusive população estimada nos domicílios fechados) 1991-2000

** Fonte: Pnud/Ipea/FJP, Atlas do Desenvolvimento Humano no Brasil.

${ }^{* \star *}$ Fonte: Datasus - Considerando apenas os óbitos e nascimentos coletados pelo SIM/SINASC

${ }^{\star * * * F o n t e: ~ I B G E ~ / ~ A g e ̂ n c i a ~ C O N D E P E / F I D E M ~-~ A n o ~ d e ~ R e f e r e ̂ n c i a: ~} 2002$ (dados sujeitos a revisão)

Sua área total é de $2.086 \mathrm{~km}^{2}$. É uma região que apresenta relevo marcado pela predominância de morros e colinas, cujas altitudes variam de 30 a mais de 400 metros e de 12 a pouco mais de 50 metros, respectivamente, configurando um plano ascendente que se eleva nos limites da Planície Costeira, para a extremidade Oeste da área onde adquirem feição de relevo montanhoso.

Pela sua localização, esse trecho do litoral pernambucano tem clima tropical úmido com chuvas de inverno antecipadas no outono. Relativamente bem distribuídas ao longo do ano, as chuvas são provocadas, sobretudo, pelos ciclones da Frente Polar Atlântica que atingem o litoral nordestino com maior vigor no período de outonoinverno, sendo os meses de maio e junho e julho os mais chuvosos e outubro, novembro e dezembro os mais secos. (LIMA, 2006, p.83)

A temperatura média anual da área é de $24^{\circ} \mathrm{C}$, variando entre a mínima de $18^{\circ} \mathrm{C}$ e a máxima de $32^{\circ} \mathrm{C}$.

Apresentando condições climáticas e solo favoráveis à exploração agrícola, a ocupação do Litoral Sul tem início na segunda metade do século XVI, quando a 
cultura da cana-de-açúcar se restringia às várzeas e terras baixas do Litoral e Zona da Mata. Até a década de 1950, as usinas de cana-de-açúcar eram maioria na geração de renda para a população residente. Nessa época, iniciam de forma bastante localizada, os primeiros incentivos à diversificação econômica, com a criação, em 1960, do Distrito Industrial do Cabo e a tentativa de implantação de um projeto de colonização nesse município.

Nos anos setenta, o Programa Nacional do Álcool (PROÁLCOOL), cuja meta era a produção em larga escala de álcool carburante a partir da cana-de-açúcar motivou a proliferação de destilarias e o aumento da demanda de matéria-prima, tendo como resultado a expansão, sem precedentes, da cultura da cana. Expansão que à custa da aquisição de pequenas propriedades e da eliminação de lavouras de subsistência, reforça a concentração fundiária e o caráter monocultor da lavoura canavieira, como também gera diversos impactos sobre os recursos naturais, destacando-se a destruição de matas e capoeiras e o aumento considerável da poluição fluvial (CPRH, 2003 apud LIMA, 2006, p.87).

Os núcleos litorâneos menos dependentes da economia açucareira continuaram a ter seu crescimento dependente da pesca (Barra do Sirinhaém), do côco (São José da Coroa Grande) e do porto marítimo (Tamandaré).

Lima (2006) faz colocações importantes a respeito do acelerado processo de expansão urbana da área, onde o autor fala que a partir dos anos setenta tem como fatores principais, a expulsão em massa de população da zona rural canavieira em decorrência da implantação do PROÁLCOOL, e a "descoberta" das praias do Litoral Sul como opção de veraneio e lazer de fim de semana, da classe média e média alta do núcleo metropolitano, em fuga das praias de Recife e municípios vizinhos já submetidos a acelerado adensamento populacional.

Primeiramente foram os pernambucanos que "invadiram" essa parte do litoral instalando-se em segundas residências, mas com um forte apelo da mídia as praias do litoral sul foram tomando espaço, despertando o interesse não só de turistas nacionais e internacionais, mas como também de investidores, interessados na localidade principalmente através de construção de meios de hospedagem luxuosos, 
onde, inevitavelmente a população que já morava no local foi "empurrada" para a região mais central dos municípios.

Lima (2006) arremata dizendo que esses loteamentos representam novos núcleos urbanos dentro de pequenas cidades e crescem no sentido da orla, afastando-se dos arredores do centro, onde a população mais antiga reside. Esses núcleos apresentam intenso movimento nos meses de dezembro a fevereiro e em feriados prolongados, mas na baixa estação parecem "cidades fantasmas", permanecendo adormecidas nas demais épocas do ano, quando residências e condomínios, em geral de alto padrão, pousadas, mercadinhos, padarias, lanchonetes e outros serviços fecham as portas até a próxima temporada.

Esses núcleos-fantasmas sofrem com o problema da sazonalidade, uma vez que a mesma infra-estrutura que deve servir a uma população de 20.000 habitantes, por exemplo, na alta estação tem que atender muitas vezes a 200.000 habitantes, causando frequentemente em alta estação, falta de água, luz, comidas em supermercados, problemas decorrentes principalmente da ausência de planejamento.

Atualmente, no litoral sul do Estado há o surgimento de novos loteamentos e a implantação de infra-estrutura e equipamentos de apoio ao turismo. O turista traz seus hábitos e costumes, muitas vezes chocantes para a população autóctone, não familiarizada com excessos de consumo e "liberdade". Há, muitas vezes, uma sensação de invasão do lugar, só compensada e/ou tolerada pelos benefícios financeiros oriundos da passagem do turista.

Pela relevância que ocupa na atividade turística no Estado de Pernambuco, a praia de Porto de Galinhas e o município onde está localizada, Ipojuca serão objetos de análise a seguir. 


\subsubsection{PORTO DE GALINHAS: A “MENINA DOS OLHOS" DO LITORAL PERNAMBUCANO}

A maioria dos resorts e grandes hotéis do Estado estão concentrados neste município e é por esse motivo que o litoral de Ipojuca será abordado com maior profundidade.

Segundo o Plano Diretor de Turismo do Município do Ipojuca (2004), a atividade turística no Município do Ipojuca desenvolveu-se na faixa de praia, notadamente no trecho que vai de Gamboa ao Portal de Maracaípe, genericamente denominada, Porto de Galinhas.

Inicialmente, era o "Turismo de Veraneio" com a aquisição ou aluguel de uma segunda residência. Em seguida, surgiu a atividade de camping com área específica explorada empresarialmente na Praia de Maracaípe hoje desativada. A beleza da área, e especialmente, da Vila de Porto de Galinhas atraiu formadores de opinião e empresários que, a partir da Década de 80 , implantaram os primeiros hotéis e pousadas no local. (EMPETUR, 2002)

Dentro deste contexto, o Plano Diretor de Turismo do Município do Ipojuca (2004) ressalta que a inexistência de uma infra-estrutura adequada ao atendimento do desenvolvimento urbano e turístico da área litorânea do Município, associada à reduzida presença, historicamente constatada, da ação fiscalizadora do cumprimento das normas legais, levou a um desequilíbrio visível entre a capacidade de suporte dos dois centros urbanos situados nas áreas turísticas litorâneas de Porto de Galinhas e Serrambi. (EMPETUR, 2002)

Assim, o Plano evidencia deficiências graves que compreendem desde 0 atendimento dos serviços públicos básicos - abastecimento de água, esgotamento sanitário, coleta e tratamento de resíduos sólidos, sinalização urbana e turística, 
segurança pública atendimento médico-hospitalar, sistema viário, controle de tráfego, dentre outros - ao atendimento insatisfatório na rede de serviços privados bares, hotéis, restaurantes - relativo à baixa capacitação dos prestadores de serviços e à ausência de gerenciamento científico nesses locais. Como agravante, o Turismo no Município atraiu atividades informais - barracas de venda de alimentos na praia, jangadas e bugue para passeio - que, além da baixa qualificação, repercutem negativamente, segundo pesquisa realizada para o Plano Diretor, em função do assédio aos turistas, pelos agenciadores de tais atividades. (EMPETUR, 2002)

Com a chegada da atividade turística, muitos pescadores transformaram-se em caseiros, vendedores ambulantes, bugueiros, comerciantes e até jangadeiros uma vez que há grande quantitativo de passeios de jangadas para as piscinas naturais, incentivados pelo crescimento do turismo na localidade.

As jangadas viraram símbolos da praia de Porto de Galinhas e a grande quantidade desse tipo de embarcação fez com que a paisagem natural fosse transformada, além disso, não há locais específicos para a lavagem das mesmas, provocando sujeira enquanto isso acontece dentro do próprio mar, junto aos banhistas.

Ausência de infra-estrutura para o turismo de excursão, provocando degradação das praias freqüentadas pelos excursionistas, e assim, gerando desconforto tanto aos visitantes como aos moradores e outros tipos de turistas, perceptível principalmente na alta estação e nos finais de semana onde se vê dentro da água, nas proximidades dos corais mais pessoas (Foto 11) do que o próprio atrativo existente na localidade que são as piscinas naturais e a grande variedade de peixes. 


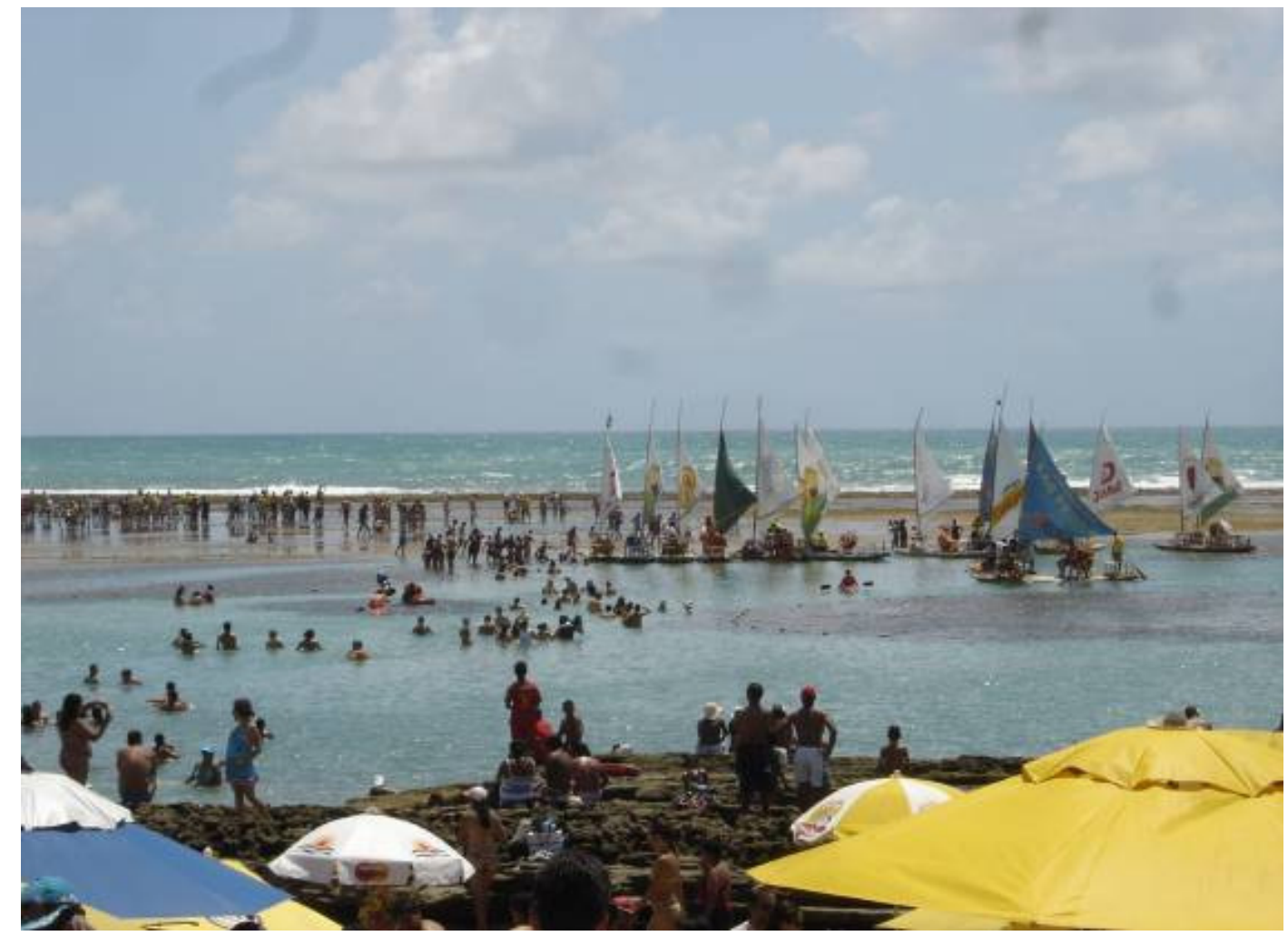

Foto 11 - Banhistas nas piscinas naturais de Porto de Galinhas, litoral sul (Fonte: Autora, 2008).

Existe também o acelerado processo de urbanização da orla litorânea, devido ao veraneio, principalmente através das segundas residências. Além disso, para a construção de equipamentos hoteleiros, especialmente os de grande porte, há uma forte devastação de remanescentes das Matas de Restinga, a exemplo da Mata de Muro Alto.

O comércio de drogas (cocaína e maconha) nas praias trazidas por turistas e ambulantes de fora, assim como também a prostituição infantil e a transmissão de doenças trazem significativos prejuízos de ordem social para Porto de Galinhas, contribuindo ainda com a insuficiência dos serviços de segurança.

Outro grande problema enfrentado na praia é a falta de estacionamento e de sinalização nos principais pólos de concentração turística, tornando o trânsito complicado em fins de semana e feriados. 
Com o trabalho de campo realizado em todas as praias de Pernambuco, inclusive em Porto de Galinhas foi possível detectar se o turismo contribuiu ou não para exacerbar esses malefícios ou, quem sabe, minimizá-los.

\subsection{ANÁLISE DOS DADOS PRIMÁRIOS ${ }^{14}$}

Com o intuito de compreender o desenvolvimento de destinos turísticos costeiros e o processo de produção desse espaço, faz-se necessário conforme nos diz Pearce apud Lima (2006) analisar alguns fatores como: características locais e elementos turísticos, como por exemplo, tipos de atração, modalidades de acomodação, meios de circulação, lojas e serviços direcionados a turistas, acomodações para os provedores desses serviços, instalações e outras funções urbanas.

Adaptaram-se neste trabalho os fatores supracitados por Pearce para preparar a tabela 5, levando-se em consideração os seguintes itens:

Modalidades de acomodação: Tomou-se por base os meios de hospedagem mais comuns na região, como, por exemplo, hotéis e pousadas. Dentro desse universo; foi visto que no litoral de Pernambuco apenas 36\% das suas praias não possuem hotéis ou pousadas de qualquer porte e que $64 \%$ as possuem, ou seja, a maioria das praias do litoral pernambucano são dotadas de infra-estrutura hoteleira, mesmo sendo de pequeno porte.

14 Durante os meses de setembro a novembro, foi realizado o trabalho de campo onde a pesquisadora percorreu todo o litoral de Pernambuco. 


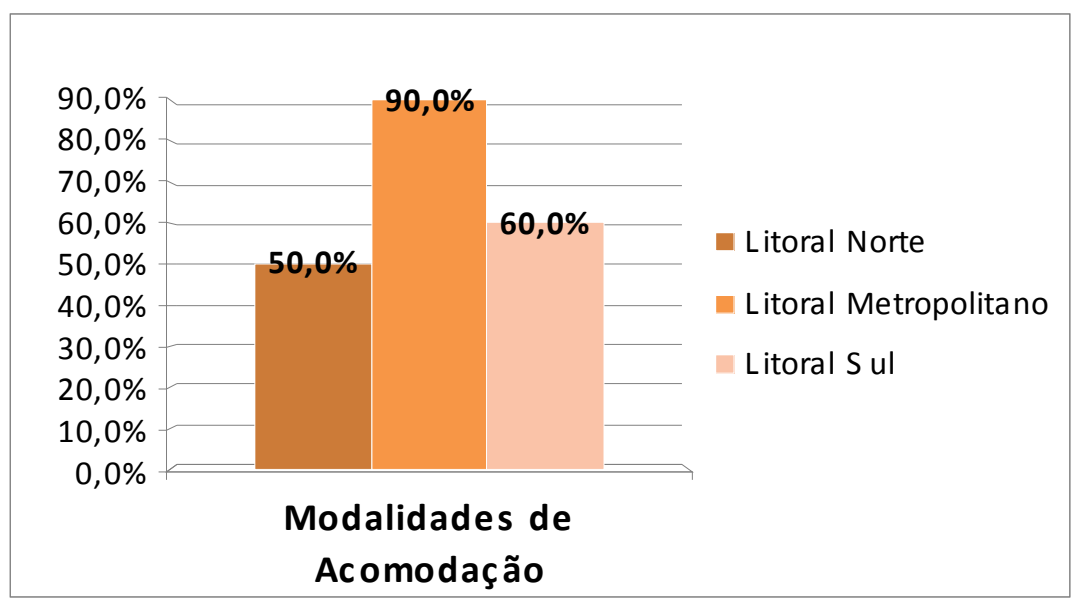

Gráfico 1 - Modalidades de acomodação

Meios de Circulação: Foram levados em consideração os meios de transportes mais usuais para se chegar até as comunidades praieiras, como, por exemplo, ônibus, vans, carros, bicicletas e motos. Os números encontrados foram que $23,5 \%$ dos municípios litorâneos pernambucanos não possuem acesso especificamente para ônibus e vans, já 76,5\% os têm, ou seja, pode-se dizer que a maioria das praias visitadas encontra-se acessíveis à população de um modo geral.

Lojas e serviços direcionados aos turistas: Esse item abordou apenas a existência ou não de lojas e serviços prestados aos turistas. Constatou-se nas visitas feitas in loco que $36 \%$ não possuem esse tipo de infra-estrutura e $64 \%$ as possuem.

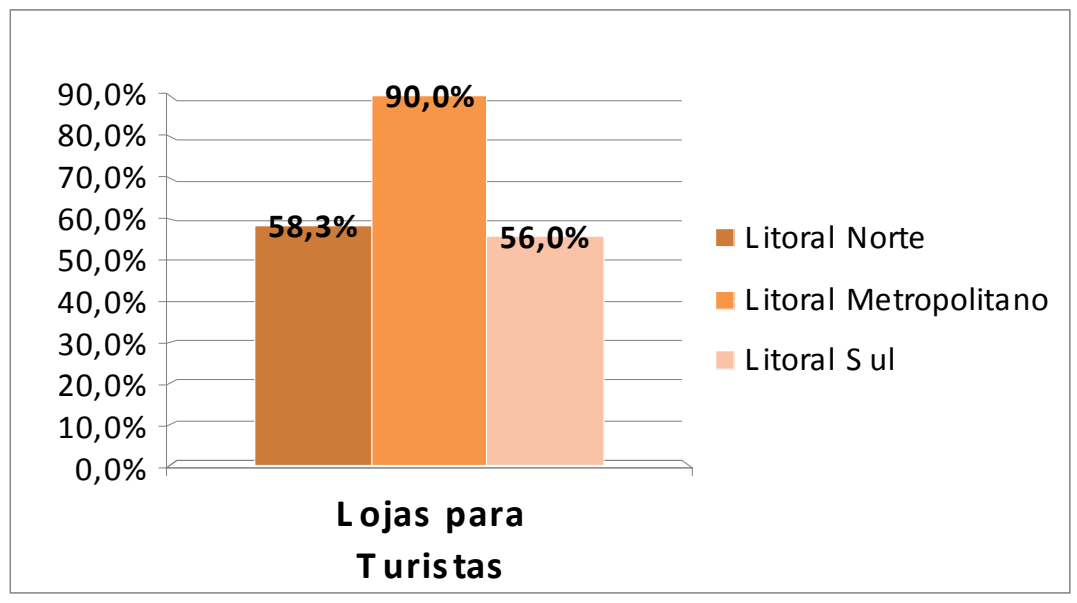

Gráfico 2 - Lojas para turistas 
Influência do turismo: o item citado informa se na localidade houve algum tipo de modificação com a chegada da atividade turística, onde foi visto que $70 \%$ dos municípios litorâneos sofreram algum tipo de influência, seja através apenas de excursões $^{15}$ ou de instalações de equipamentos turísticos ${ }^{16}$. No universo pesquisado, 30\% das praias ainda não tiveram esse tipo de influência.

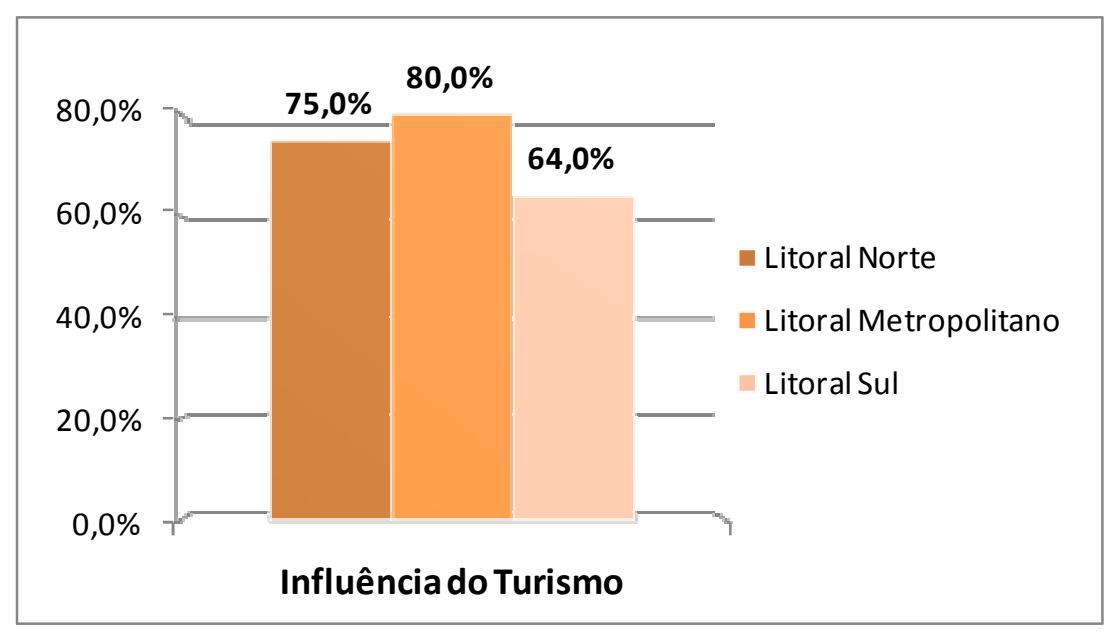

Gráfico 3 - Influência do Turismo

Segundas Residências: No tocante às segundas residências, foi pesquisado se havia presença de casas de veraneio nas praias. No litoral pernambucano 64\% possuem o fenômeno da segunda residência, $14 \%$ as não possuem e $22 \%$ são consideradas praias urbanas, por isso não são contabilizadas como segundas residências.

${ }^{15}$ É considerada uma excursão quando se passa no local visitado um período de até 24hs.

${ }^{16}$ Equipamentos Turísticos são construções que permitem a prestação de serviços turísticos (alojamentos, nos núcleos receptores; agências, nos núcleos emissores; transportadoras entre ambos). (BARRRETO, 2001, p.39) 


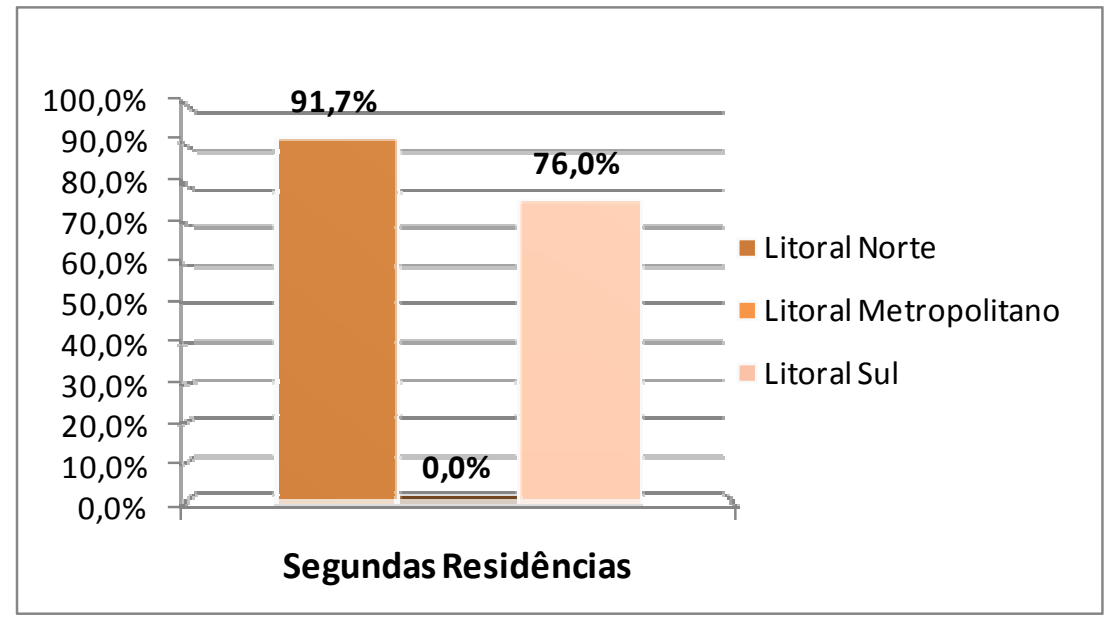

Gráfico 4 - Segundas Residências

Os números totais podem ser visualizados no Gráfico 5:

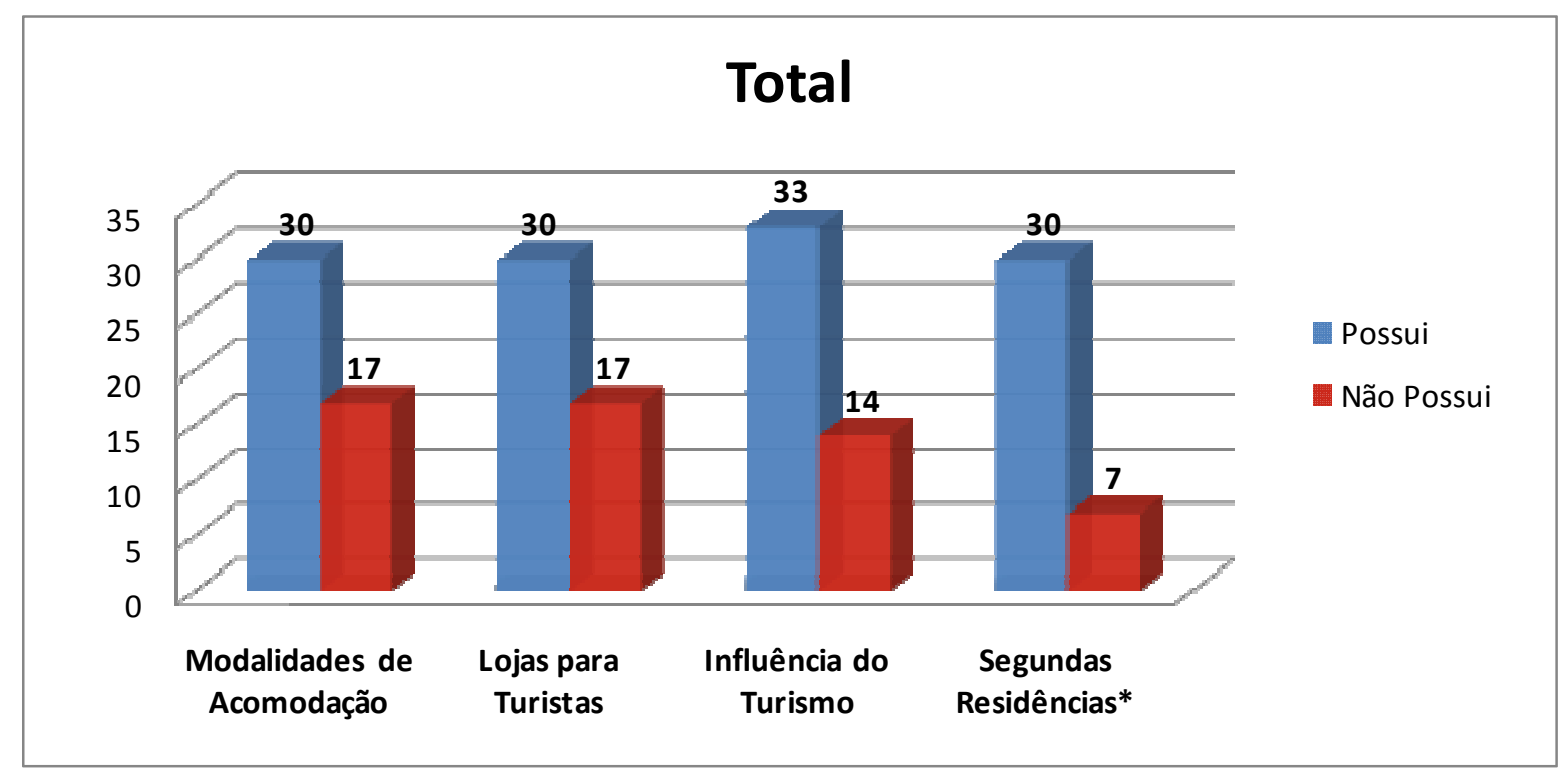

Gráfico 5 - Números Globais

Os tipos de atração, as acomodações para os provedores de serviços e instalações citados por Pearce, não foram consideradas relevantes para o presente trabalho. 
Os dados e resultados compilados do trabalho de campo ficaram da seguinte forma:

Tabela 6 - Informações coletadas no trabalho de campo

\begin{tabular}{|c|c|c|c|c|c|}
\hline PRAIAS & $\begin{array}{l}\text { MODALIDADES DE } \\
\text { ACOMODAÇÃO }\end{array}$ & $\begin{array}{c}\text { MEIOS DE } \\
\text { CIRCULAÇÃO }\end{array}$ & $\begin{array}{l}\text { LOJAS PARA } \\
\text { TURISTA }\end{array}$ & $\begin{array}{l}\text { INFLUÊNCIA } \\
\text { DO TURISMO }\end{array}$ & $\begin{array}{l}\text { SEGUNDAS } \\
\text { RESIDÊNCIAS }\end{array}$ \\
\hline \multicolumn{6}{|c|}{ Litoral Norte } \\
\hline Carne de Vaca & Não possui & Todos os citados & Não possui & Possui & Sim \\
\hline Catuama & Não possui & $\begin{array}{l}\text { Todos exceto } \\
\text { ônibus e vans }\end{array}$ & Não possui & Possui & $\operatorname{Sim}$ \\
\hline $\begin{array}{c}\text { Ponta de } \\
\text { Pedras }\end{array}$ & Possui & Todos os citados & Possui & Possui & Sim \\
\hline Atapuz & Não possui & $\begin{array}{l}\text { Todos exceto } \\
\text { ônibus e vans } \\
\end{array}$ & Não possui & Não possui & Sim \\
\hline $\begin{array}{c}\text { Ilha de } \\
\text { Itamaracá }\end{array}$ & Possui & Todos os citados & Possui & Possui & $\operatorname{Sim}$ \\
\hline $\begin{array}{l}\text { Praia do } \\
\text { Sossego }\end{array}$ & Não possui & $\begin{array}{l}\text { Todos exceto } \\
\text { ônibus e vans }\end{array}$ & Não possui & Não possui & Sim \\
\hline $\begin{array}{c}\text { Praia de } \\
\text { Jaguaribe }\end{array}$ & Não possui & Todos os citados & Possui & Possui & $\operatorname{Sim}$ \\
\hline Gavoa & Possui & Todos os citados & Possui & Possui & Sim \\
\hline Maria Farinha & Possui & Todos os citados & Possui & Possui & $\operatorname{Sim}$ \\
\hline Conceição & Não possui & $\begin{array}{l}\text { Todos exceto } \\
\text { ônibus e vans } \\
\end{array}$ & Não possui & Não possui & Não \\
\hline Pau Amarelo & Possui & Todos os citados & Possui & Possui & Sim \\
\hline Janga & Possui & Todos os citados & Possui & Possui & Sim \\
\hline \multicolumn{6}{|c|}{ Litoral Metropolitano } \\
\hline $\begin{array}{c}\text { Nossa Senhora } \\
\text { do Ó }\end{array}$ & Possui & Todos os citados & Possui & Possui & - \\
\hline Rio Doce & Possui & Todos os citados & Possui & Possui & - \\
\hline Casa Caiada & Possui & Todos os citados & Possui & Possui & - \\
\hline Bairro Novo & Possui & Todos os citados & Possui & Possui & - \\
\hline $\begin{array}{c}\text { Praia Del } \\
\text { Chifre }\end{array}$ & Não Possui & $\begin{array}{l}\text { Todos exceto } \\
\text { ônibus e vans } \\
\end{array}$ & Não possui & Não possui & - \\
\hline $\begin{array}{l}\text { Brasília } \\
\text { Teimosa }\end{array}$ & Possui & Todos os citados & Possui & Não possui & - \\
\hline Boa Viagem & Possui & Todos os citados & Possui & Possui & - \\
\hline Piedade & Possui & Todos os citados & Possui & Possui & - \\
\hline Candeias & Possui & Todos os citados & Possui & Possui & - \\
\hline $\begin{array}{l}\text { Barra de } \\
\text { Jangada }\end{array}$ & Possui & Todos os citados & Possui & Possui & - \\
\hline \multicolumn{6}{|c|}{ Litoral Sul } \\
\hline
\end{tabular}




\begin{tabular}{|c|c|c|c|c|c|}
\hline Paiva & Não Possui & $\begin{array}{l}\text { Todos exceto } \\
\text { ônibus e vans }\end{array}$ & Não possui & Possui & Sim \\
\hline Itapuama & Possui & Todos os citados & Possui & Possui & Sim \\
\hline Pedra do Xaréu & Não Possui & Todos os citados & Não possui & Não possui & Não \\
\hline $\begin{array}{l}\text { Enseada dos } \\
\text { Corais }\end{array}$ & Possui & Todos os citados & Possui & Possui & Sim \\
\hline Gaibu & Possui & Todos os citados & Possui & Possui & Sim \\
\hline Calhetas & Possui & Todos os citados & Possui & Possui & Sim \\
\hline $\begin{array}{c}\text { Santo } \\
\text { Agostinho }\end{array}$ & Não Possui & $\begin{array}{l}\text { Todos exceto } \\
\text { ônibus e vans }\end{array}$ & Não possui & Não possui & Não \\
\hline Paraíso & Possui & $\begin{array}{l}\text { Todos exceto } \\
\text { ônibus e vans }\end{array}$ & Não possui & Possui & Sim \\
\hline Suape & Possui & Todos os citados & Possui & Possui & Sim \\
\hline Camboa & Não possui & Todos os citados & Não possui & Não possui & Não \\
\hline Muro Alto & Possui & Todos os citados & Possui & Possui & Sim \\
\hline Cupe & Possui & Todos os citados & Possui & Possui & Sim \\
\hline $\begin{array}{l}\text { Porto de } \\
\text { Galinhas }\end{array}$ & Possui & Todos os citados & Possui & Possui & Sim \\
\hline Maracaípe & Possui & Todos os citados & Possui & Possui & Sim \\
\hline Serrambi & Possui & Todos os citados & Possui & Possui & Sim \\
\hline Cacimbas & Não Possui & Todos os citados & Não possui & Não possui & Não \\
\hline Toquinho & Não possui & Todos os citados & Não possui & Não possui & Sim \\
\hline $\begin{array}{c}\text { Barra de } \\
\text { Sirinhaém e } \\
\text { Gamela }\end{array}$ & Possui & Todos os citados & Possui & Possui & Sim \\
\hline Guadalupe & Não possui & $\begin{array}{l}\text { Todos exceto } \\
\text { ônibus e vans }\end{array}$ & Não possui & Não possui & Sim \\
\hline Carneiros & Possui & Todos os citados & Possui & Possui & Sim \\
\hline Tamandaré & Possui & Todos os citados & Possui & Possui & Sim \\
\hline Boca da Barra & Não possui & Todos os citados & Não possui & Não possui & Não \\
\hline Praia do Porto & Não possui & $\begin{array}{l}\text { Todos exceto } \\
\text { ônibus e vans }\end{array}$ & Não possui & Não possui & Sim \\
\hline Várzea do Una & Não possui & $\begin{array}{l}\text { Todos exceto } \\
\text { ônibus e vans }\end{array}$ & Não possui & Não possui & Não \\
\hline $\begin{array}{l}\text { São José da } \\
\text { Coroa Grande }\end{array}$ & Possui & Todos os citados & Possui & Possui & Sim \\
\hline
\end{tabular}

No Inventário do Potencial Turístico de Ipojuca, Teixeira e Kano (2002) identificaram no que se referem à infra-estrutura turística, as seguintes deficiências para o município acima citado que poderiam ser estendidas a praticamente todo o litoral pernambucano: 
Falta de centros de informações turísticas - Resulta na falta de atendimento adequado ao turista, deixando de informar e divulgar junto aos turistas reais, que são ao mesmo tempo consumidores potenciais, os diversos atrativos e segmentos de oferta existentes no Pólo e em todo Estado de Pernambuco.

Falta de Saneamento Básico - A falta de condições sanitárias, resultante da desproporcional coleta de lixo/produção desfigura a paisagem, sua beleza, impede que o fluxo cresça, e até mesmo que os turistas voltem.

Falta de Sinalização Turística - A falta de sinalização turística dificulta a movimentação do turista no interior do destino e áreas vizinhas. A própria comunidade local seria também beneficiada com a sua implantação, pois a sinalização turística é em muitos momentos uma sinalização urbana.

Deficiência de Abastecimento de Água, Coleta e Tratamento de Resíduos Sólidos, Serviços de Urgência Médica e Segurança Pública - O aumento do fluxo de turistas acarretou uma crescente demanda por serviços e infra-estrutura pública em períodos de alta estação;

Atendimento Insatisfatório pela Rede de Serviços Privados - Resulta do baixo nível de qualificação da mão de obra que atende ao turista em bares, restaurantes e hotéis e da falta de gerenciamento eficiente, na maior parte dos estabelecimentos.

Além dessas deficiências supracitadas, foram diagnosticados mais alguns pontos a serem levados em consideração, sendo estes: construções feitas fora do permitido pelos Planos Diretores vigentes, comprometendo a faixa que se encontra a beiramar; desorganização no tocante a comercialização do artesanato local, quando existe esse tipo de atrativo, comercializando muitas vezes produtos "padronizados", sem diferencial de outros estados do Nordeste, por exemplo; falta de comprometimento com a qualidade dos serviços por parte de empreendimentos 
privados, contratando mão-de-obra não especializada em prol de um baixo custo, praias com grande carência de um sistema de tratamento de esgoto, onde percebese claramente o desaguar dos mesmos diretamente nas praias, Falta de sinalização, sem indicações para chegar até as praias; ausência de estacionamentos para carros de passeios, assim como também para ônibus e vans; periculosidade no que diz respeito a assaltos com falta de policiamento na região, principalmente nas praias do Litoral Norte.

De uma forma geral, o litoral pernambucano sofreu influência com a chegada da atividade turística. Percebe-se que o turismo "aconteceu" nos municípios de forma espontânea e não planejada, o que pode acarretar malefícios para a localidade, como já abordado anteriormente.

As segundas residências são a forma mais comum de dominação do espaço costeiro pernambucano. $O$ hábito de freqüentar as praias principalmente nos finais de semana, provocam a sazonalidade, fenômeno usual em locais turísticos, principalmente os que não possuem planejamento turístico.

A maioria das praias do litoral pernambucano têm meios de acesso para se chegar até ela, embora algumas só possam ser acessadas através de meios de transportes pequenos, devido também à pouca infra-estrutura de acesso. No que diz respeito à infra-estrutura hoteleira, percebeu-se que a maioria dessas praias tem algum tipo de meios de hospedagem, sejam pousadas, albergues, campings ou até mesmo grandes hotéis, onde as praias do litoral sul são as que mais possuem este último tipo.

Percebe-se ainda a carência de infra-estrutura básica para o turista, seja no tocante aos banheiros públicos (Foto 12) para atender a grande demanda, ou até mesmo na precariedade das sinalizações nos atrativos ou no caminho até eles. (Foto 13). 


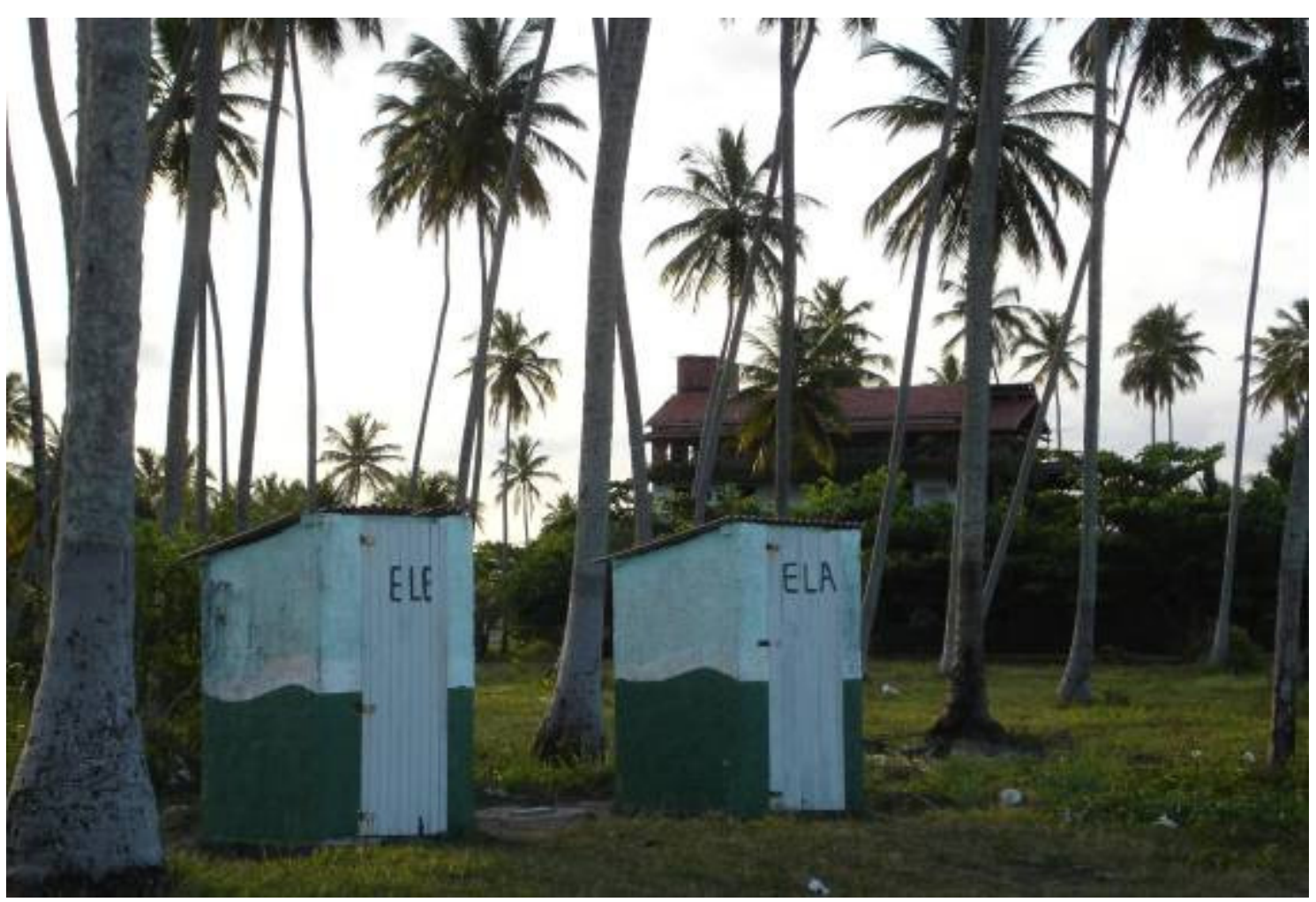

Foto 12 - Banheiros Públicos localizados na praia de Gamela, Litoral sul (Fonte: Autora, 2008).

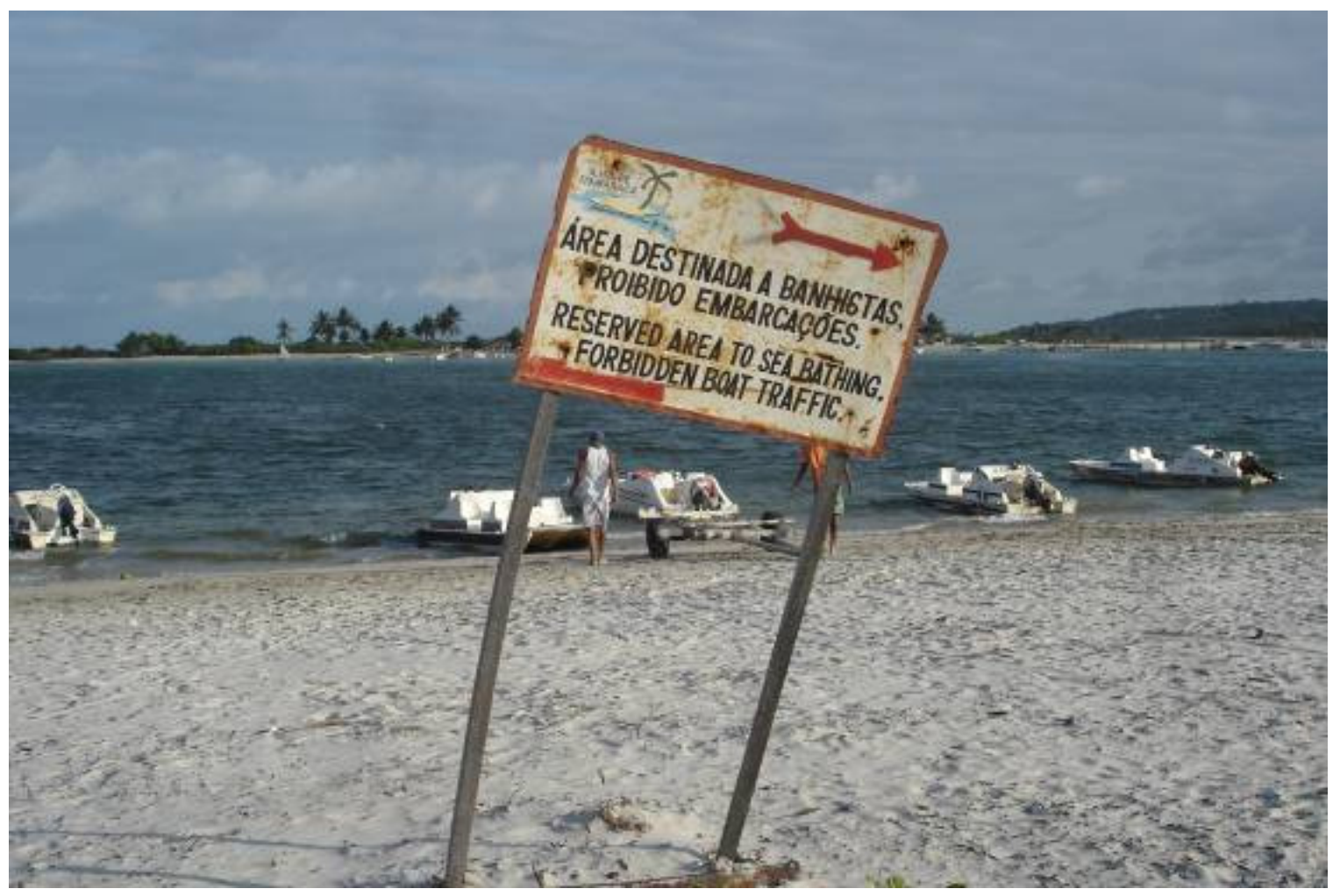

Foto 13 - Placa de sinalização, praia de Itamaracá, litoral norte (Fonte: Autora, 2008). 
O litoral norte do Estado, embora ainda possua uma relativa visitação de turistas ao longo do ano, encontra-se carente de ações onde o turismo possa ser novamente prioridade.

O incentivo à criação de produtos turísticos voltados para públicos diversos, com mercado alternativos ao turismo de massa, amplamente praticado, assim como também o fomento à ampliação espacial dos destinos turísticos do estado, visando à interiorização e desconcentração da atividade no litoral e ainda procurando atuar conforme marcos regulatório e legal do estado são alternativas para desenvolver uma atividade com perspectiva de crescimento ordenado em Pernambuco. 


\section{CONSIDERAÇÕES FINAIS}

O Turismo enquanto atividade social transforma cada vez mais o espaço. O litoral de Pernambuco, assim como em diversas praias do Nordeste brasileiro é palco da modificação ocorrida por tal atividade, seja por meio das instalações dos equipamentos que o turismo requer ou apenas com a presença de turistas na localidade, mesmo sem a infra-estrutura necessária.

Nas décadas de setenta e oitenta, a rede hoteleira instalou-se nos municípios litorâneos do estado, principalmente nas praias do litoral metropolitano.

O Estado através das suas políticas públicas, ou da ausência delas também foi um agente modificador nesse processo de produção do espaço no litoral de Pernambuco. Na grande maioria das praias pesquisadas, percebeu-se a ausência do planejamento turístico, seja ele de curto ou longo prazo. Somente no ano de 2008, o Governo do Estado lançou um planejamento estratégico de longa duração visando ações para o desenvolvimento turístico em áreas prioritárias para o litoral do Estado.

Ao turismo é atribuído uma das maiores responsabilidades na transformação no litoral de Pernambuco, assim como também ao fenômeno das segundas residências. Em quase toda a totalidade das suas praias já existia assentamento humano prévio quando o turismo instalou-se nestas.

O litoral norte de Pernambuco teve seu apogeu nas décadas de setenta e oitenta, mas com a proliferação do turismo na praia de Porto de Galinhas, litoral sul do Estado, a porção norte do litoral caiu no "esquecimento", só voltando a receber um número significativo de turistas em feriados. Com o lançamento do Planejamento estratégico onde estão contempladas algumas ações, visando o retorno dos turistas 
com obras de melhorias aos equipamentos já existentes e instalação de alguns novos, além da retirada do presídio existente na llha de Itamaracá.

O setor metropolitano, especialmente a praia de Boa Viagem, além da influência do turismo na sua urbanização, teve também a influência da especulação imobiliária e com isso aumentou consideravelmente o custo de vida da população.

Atualmente, é o litoral sul de Pernambuco que se concentra o maior número de turistas e investimentos relacionados ao turismo. Os hotéis e resorts estão fragmentando cada vez mais o referido espaço e reorganizando de acordo com os seus interesses.

Tomando por base Pearce apud Lima (2006) que estabeleceu alguns fatores para determinar o processo de produção do espaço turístico, foi realizado um trabalho de campo durante todo o litoral pernambucano a fim de encontrar os aspectos que detectasse essa produção, sendo estes, as modalidades de ocupação, os meios de circulação, as lojas e serviços direcionados aos turistas e a presença de segundas residências.

O turismo sem planejamento, gestão e o controle da atividade acaba provocando em algumas localidades o uso indiscriminado do espaço litorâneo. O adensamento das construções, sobretudo no litoral sul do Estado acarreta sérios problemas de saneamento, falta de água e de poluição, além de graves problemas sociais.

Diante disso, considera-se de extrema importância um plano de ação para coibir tais problemas, não só elaborar projetos "tapa buracos" pensado apenas para o período de alta estação (normalmente entre dezembro a fevereiro), quando todos esses fatores negativos vêm com maior visibilidade à tona. 
Nas praias de Pernambuco onde as segundas residências ocupam grande parte, há conflito de interesses entre os seus proprietários e os antigos moradores empurrados para o centro da cidade. Os interesses dos primeiros normalmente se sobrepõem aos dos segundo.

A sazonalidade da demanda é perceptível nos destinos turísticos pernambucanos onde os meses de férias escolares, durante o verão brasileiro - dezembro a fevereiro são os que mais recebem visitantes, acarretando uma superlotação desses destinos e, em contrapartida, têm-se empreendimentos sofrendo com a baixa ocupação fora desse período.

Entender a influência que o turismo teve na produção do espaço litorâneo em Pernambuco foi o propósito desse trabalho. 


\section{REFERÊNCIAS}

ALECRIM, Elysio. A Fisiografia e o Turismo de Pernambuco. Recife: Ed. Do Autor, 2003. b

ANSARAH, Marília Gomes dos Reis (org.). Turismo: como aprender, como ensinar. Vol.2. 2ed. São Paulo: Senac, 2001.

ARAÚJO, Rita de Cássia Barbosa de. As praias e os dias: história social das praias de Recife e de Olinda. Recife: Fundação de Cultura Cidade do Recife, 2007.

ASSIS, Lenilton Francisco de. Turismo e Representações na Ilha de Itamaracá (PE): O Espaço vivido em foco. Turismo em Análise. V.14. n.1. Pg.117 - 130, maio, 2003. ISSN0103-5541.

BARRETO, Margarita. Manual de iniciação do estudo do turismo. 10ed. Campinas SP - Papirus, 2001.

BARROS JUNIOR, Noberto Francisco de. "A dinâmica espacial e a reorganização territorial do Litoral de Ipojuca/PE: Porto de Galinhas - A emergência do Espaço Turístico". Dissertação (Curso de Mestrado em Geografia). Centro de Filosofia e Ciências Humanas - UFPE. Recife, 2002.

BECKER, Bertha K. Levantamento e avaliação da política federal de turismo e seu impacto na região costeira. Brasília: Ministério do meio Ambiente, dos Recursos Hídricos e da Amazônia Legal, 1995.

BERVIAN, Pedro Alcino, CERVO, Arnaldo Luiz. Metodologia Científica. São PauloSP: Makron Books do Brasil, 1996.

BOYER, Marc. História do turismo de massa. Bauru: EDUSC, 2003.

BULL, A. La economia Del setor turístico. Madrid: Alianza editorial, 1994

CARLOS, Ana Fani Alessandri. O Consumo do Espaço. In: Novos caminhos da Geografia. São Paulo: Contexto, 1999.

. O lugar no/do mundo. São Paulo: Hucitec, 1996.

Espaço-tempo na metrópole. São Paulo: Contexto, 2001.

CPRH. Diagnóstico Socioambiental - Litoral Norte. Recife, 2003.

CRUZ, Rita de Cássia Ariza da. Os paradoxos do turismo na cidade de São Paulo. In: CARLOS, Ana Fani \& OLIVEIRA, Ariovaldo U. (orgs.) Geografia das metrópoles. São Paulo: Contexto, 2005, pp.201-212.

. Política de Turismo e Território. São Paulo: Contexto, 2002. 
2007.

.Geografias do turismo: de lugares a pseudo-lugares. São Paulo: Roca,

DIAS, Reinaldo. Planejamento do turismo: política e desenvolvimento do turismo no Brasil. São Paulo: Atlas, 2003.

DUARTE, Vladir Vieira. Administração de Sistemas Hoteleiros: Conceitos Básicos. 3ed. São Paulo: Senac, 2005.

DOMINGUEZ, J. M. L.; BITTENCOURT, A. C. S. P.; IEÃO, Z. M. A. N. \& AZEVEDO, A. E. G. (1990). Geologia do Quaternário Costeiro do Estado de Pernambuco. Revista Brasileira de Geociências, 20: 208 - 215.

EMPETUR. Inventário do Potencial Turístico de Pernambuco. Recife, 1998. Atualização 2002.

FARIAS, Fabiana Santos de. "Tamoindaré - a dinâmica de suas praias frente às novas tribos repovoadoras do Século XX". Dissertação (Curso de Mestrado em Geografia). Centro de Filosofia e Ciências Humanas - UFPE. Recife, 2002.

FIRMINO, Fabiana dos Santos. Dinâmica do Turismo na Zona Costeira Nordestina: Questões conflitantes com o desenvolvimento turístico da Praia dos Carneiros. Dissertação (Curso de Mestrado em Gestão e Políticas Ambientais). Centro de Filosofia e Ciências Humanas - UFPE. Recife, 2006.

GIL, Antônio C. Como elaborar projetos de pesquisa. São Paulo-SP: Atlas, 1991.

IBGE. Sinopse Preliminar do censo demográfico 2000 - Brasil. Disponível em: http://www.ibge.gov.br. Acesso em: 30/05/2001.

Jornal do Comércio - Caderno Ciência e Meio Ambiente - 23.05.1999.

KNAFOU, R. Turismo e território: para um enfoque científico do turismo. In: RODRIGUES, A. B. Turismo e geografia: reflexões teóricas e enfoques regionais. 3. ed. São Paulo: HUCITEC, 2001. p. 62 - 74.

LEITE, Adriana Filgueira. O Lugar: Duas Acepções Geográficas. Anuário do Instituto de Geografia - RJ. Volume 21. 1998.

LIMA, Clarisse Vasconcelos Fraga de Melo. "Urbanização turística no litoral sul de Pernambuco: O caso do município de Tamandaré”. Dissertação (Curso de Mestrado em Geografia). Centro de Filosofia e Ciências Humanas - UFPE. Recife, 2006.

LINHARES, Paulo. Cidade de Água e Sal: Por uma Antropologia do Litoral, Nordeste sem Cana e sem Açúcar. Fortaleza. Ed. Fundação Demócrito Rocha, 1992. 364p. 
LUKÁCS, György. Per l'ontologia dell'essere sociale. Roma, Editori Riuniti, 3 vols. 1976.

MADRUGA, Antonio Moacyr. "Litoralização: Da Fantasia de liberdade à modernidade autofágica". Dissertação (Curso de Mestrado em Geografia). Departamento de Geografia da Faculdade de Filosofia, Letras e Ciências Humanas - USP. São Paulo, 1992.

MARTINS, Joel. Subsídio para redação de dissertação de mestrado e tese de doutorado. 3ed. São Paulo-SP: Moraes, 1991.

MILES, M.B.; HUBERMAN, A. M. Qualitative data analysis: an expanded Sourcebook. California: Sage, 1994.

MOESCH, Marustschka Martini. A produção do saber. São Paulo: Contexto: 2002.

MORAES, Antonio Carlos Robert. Contribuições para a gestão da zona costeira do Brasil: elementos para uma geografia do litoral brasileiro. São Paulo: Hucitec/Edusp, 1999.

Hucitec, 1988.

Ideologias Geográficas: Espaço, Cultura e Política no Brasil. São Paulo:

. Capitalismo, Geografia e Meio Ambiente. Tese inédita de obtenção de título de Livre Docente. FFLCH, USP: São Paulo, 2000.

. Território e História no Brasil. São Paulo:HUCITEC, 2002.

Território, poder e justiça: comentários a partir da experiência brasileira. In:

Kritsch, R. \& Ricupero B. (orgs.) Força e Legitimidade: Novas Perspectivas? São Paulo: NADD/ Humanitás, 2005.

OMT. Código Mundial de Ética do Turismo. Chile, 1999.

PERNAMBUCO: Secretaria de Planejamento e Desenvolvimento Social. Fundação de Desenvolvimento Municipal - FIDEM. Litoral de Pernambuco: um estudo propositivo. Recife, novembro/1999.

POLICONSULT. Plano Diretor Urbanístico do Município do Ipojuca. Recife, 2004.

RUSCHMANN. Doris. Turismo e Planejamento sustentável. Campinas: Papirus, 1997.

SANTOS, Milton. Técnica, espaço, tempo: globalização e meio técnico-científico informacional. 4 ed. São Paulo: Hucitec, 1994. 
Hucitec, 1996.

A natureza do espaço - Técnica e tempo, razão e emoção. São Paulo: . Por uma outra globalização. 13 ed. Rio de Janeiro: Record, 2006.

SETUR/PE. Pernambuco para o Mundo - Planejamento Estratégico 2008 a 2020. Recife, 2008.

SILVA, Jacqueline S. et al. Ocupação da praia da Boa Viagem (Recife/PE) ao longo de dois dias de verão: um estudo preliminar.. Pan-American Journal of Aquatic Sciences (2006).

SILVEIRA, Maria Laura. "Uma situação geográfica: do método à metodologia", in Território, Laboratório de Gestão de Território - LAGET, Universidade Federal do Rio de Janeiro, ano IV, n.6, janeiro-junho 1999, pp.21-28.

SMITH, Neil. Desenvolvimento desigual. Rio de Janeiro: Bertrand Brasil, 1988.

SOUZA, Celina. Políticas públicas: uma revisão da literatura. Sociologias. n.16 Porto Alegre jul./dez. 2006.

TEIXEIRA, Elder L.; KANO, S. Inventário do Potencial Turístico de Ipojuca: equipamentos e serviços turísticos, infra-estrutura de apoio turístico. Fev. 2002.

TULIK, Olga. Residências secundárias: presença, dimensão e expressividade do fenômeno no Estado de São Paulo. 1995. 154 f. Tese (Livre-Docência) - Escola de Comunicações e Artes, Universidade de São Paulo. São Paulo.

. Turismo e Meios de Hospedagem: casa de temporada. São Paulo: Roca, 2001.

YÁZIGI, Eduardo (org). Turismo e Paisagem. São Paulo, Contexto, 2002.

www.cprh.pe.gov.br, acessado dia 01/12/2008 às 14h30min.

www.mma.gov.br/estruturas/orla/_arquivos/pngc2.pdf, acessado dia 13/02/2009 às 10hs. 